Bridgewater State University

2011

\title{
Geochemistry of hydrothermal fluids from the PACMANUS, Northeast Pual and Vienna Woods hydrothermal fields, Manus Basin, Papua New Guinea
}

Eoghan P. Reeves

Jeffrey S. Seewald

Peter Saccocia

BridgewaterState University, psaccocia@bridgew.edu

Wolfgang Bach

Paul R. Craddock

See next page for additional authors

Follow this and additional works at: http://vc.bridgew.edu/geology_fac

Part of the Earth Sciences Commons

\section{Virtual Commons Citation}

Reeves, Eoghan P.; Seewald, Jeffrey S.; Saccocia, Peter; Bach, Wolfgang; Craddock, Paul R.; Shanks, Wayne C. III; Sylva, Sean P.; Walsh, Emily; Pichler, Thomas; and Rosner, Martin (2011). Geochemistry of hydrothermal fluids from the PACMANUS, Northeast Pual and Vienna Woods hydrothermal fields, Manus Basin, Papua New Guinea. In Geological Sciences Faculty Publications. Paper 9. Available at: http://vc.bridgew.edu/geology_fac/9 


\section{Authors}

Eoghan P. Reeves, Jeffrey S. Seewald, Peter Saccocia, Wolfgang Bach, Paul R. Craddock, Wayne C. Shanks III, Sean P. Sylva, Emily Walsh, Thomas Pichler, and Martin Rosner 


\title{
Geochemistry of hydrothermal fluids from the PACMANUS, Northeast Pual and Vienna Woods hydrothermal fields, Manus Basin, Papua New Guinea
}

\author{
Eoghan P. Reeves ${ }^{a, b, *}$, Jeffrey S. Seewald ${ }^{b}$, Peter Saccocia ${ }^{c}$, Wolfgang Bach ${ }^{d}$, \\ Paul R. Craddock ${ }^{\mathrm{a}, \mathrm{b}}$, Wayne C. Shanks ${ }^{\mathrm{e}}$, Sean P. Sylva ${ }^{\mathrm{b}}$, Emily Walsh ${ }^{\mathrm{c}}$, \\ Thomas Pichler $^{\mathrm{d}}$, Martin Rosner ${ }^{\mathrm{d}, \mathrm{f}}$ \\ ${ }^{a}$ MIT/WHOI Joint Program in Oceanography, MA 02543, USA \\ ${ }^{\mathrm{b}}$ Department of Marine Chemistry and Geochemistry, Woods Hole Oceanographic Institution, 360 Woods Hole Road, \\ Woods Hole, MA 02543, USA \\ ${ }^{\mathrm{c}}$ Department of Earth Sciences, Bridgewater State College, Bridgewater, MA 02325, USA \\ ${ }^{\mathrm{d}}$ Department of Geosciences, University of Bremen, 2 Klagenfurter Str. 28359 Bremen, Germany \\ ${ }^{\mathrm{e}}$ U.S. Geological Survey, 973 Denver Federal Center, Denver, CO 80225, USA \\ ${ }_{\mathrm{f}}^{\mathrm{f}}$ Fachbereich Geowissenschaften, Freie Universität Berlin, Malteserstr. 74-100, 12249 Berlin, Germany
}

Received 11 December 2009; accepted in revised form 9 November 2010; available online 17 November 2010

\begin{abstract}
Processes controlling the composition of seafloor hydrothermal fluids in silicic back-arc or near-arc crustal settings remain poorly constrained despite growing evidence for extensive magmatic-hydrothermal activity in such environments. We conducted a survey of vent fluid compositions from two contrasting sites in the Manus back-arc basin, Papua New Guinea, to examine the influence of variations in host rock composition and magmatic inputs (both a function of arc proximity) on hydrothermal fluid chemistry. Fluid samples were collected from felsic-hosted hydrothermal vent fields located on Pual Ridge (PACMANUS and Northeast (NE) Pual) near the active New Britain Arc and a basalt-hosted vent field (Vienna Woods) located farther from the arc on the Manus Spreading Center. Vienna Woods fluids were characterized by relatively uniform endmember temperatures $\left(273-285^{\circ} \mathrm{C}\right)$ and major element compositions, low dissolved $\mathrm{CO}_{2}$ concentrations $(4.4 \mathrm{mmol} / \mathrm{kg})$ and high measured $\mathrm{pH}\left(4.2-4.9\right.$ at $\left.25^{\circ} \mathrm{C}\right)$. Temperatures and compositions were highly variable at PACMANUS/NE Pual and a large, newly discovered vent area (Fenway) was observed to be vigorously venting boiling $\left(358{ }^{\circ} \mathrm{C}\right.$ ) fluid. All PACMANUS fluids are characterized by negative $\delta \mathrm{D}_{\mathrm{H}_{2} \mathrm{O}}$ values, in contrast to positive values at Vienna Woods, suggesting substantial magmatic water input to circulating fluids at Pual Ridge. Low measured $\mathrm{pH}\left(25^{\circ} \mathrm{C}\right)$ values $(\sim 2.6-$ 2.7), high endmember $\mathrm{CO}_{2}$ (up to $274 \mathrm{mmol} / \mathrm{kg}$ ) and negative $\delta^{34} \mathrm{~S}_{\mathrm{H}_{2} \mathrm{~S}}$ values (down to $-2.7 \%$ ) in some vent fluids are also consistent with degassing of acid-volatile species from evolved magma. Dissolved $\mathrm{CO}_{2}$ at PACMANUS is more enriched in ${ }^{13} \mathrm{C}(-4.1 \%$ to $-2.3 \%$ o $)$ than Vienna Woods $(-5.2 \%$ to $-5.7 \%)$, suggesting a contribution of slab-derived carbon. The mobile elements (e.g. Li, K, Rb, Cs and B) are also greatly enriched in PACMANUS fluids reflecting increased abundances in the crust there relative to the Manus Spreading Center. Variations in alkali and dissolved gas abundances with $\mathrm{Cl}$ at PACMANUS and NE Pual suggest that phase separation has affected fluid chemistry despite the low temperatures of many vents. In further contrast to Vienna Woods, substantial modification of PACMANUS/NE Pual fluids has taken place as a result of seawater ingress into the upflow zone. Consistently high measured $\mathrm{Mg}$ concentrations as well as trends of increasingly non-conservative $\mathrm{SO}_{4}$ behavior, decreasing endmember $\mathrm{Ca} / \mathrm{Cl}$ and $\mathrm{Sr} / \mathrm{Cl}$ ratios with increased $\mathrm{Mg}$ indicate extensive
\end{abstract}

\footnotetext{
* Corresponding author. Present address: Department of Geosciences, University of Bremen, 2 Klagenfurter Str. 28359 Bremen, Germany. Tel.: +49 42121865416.

E-mail addresses: ereeves@whoi.edu, reeves@uni-bremen.de (E.P. Reeves).
} 
subsurface anhydrite deposition is occurring as a result of subsurface seawater entrainment. Decreased $\mathrm{pH}$ and endmember $\mathrm{Fe} / \mathrm{Mn}$ ratios in higher $\mathrm{Mg}$ fluids indicate that the associated mixing/cooling gives rise to sulfide deposition and secondary acidity production. Several low temperature $\left(\leqslant 80^{\circ} \mathrm{C}\right)$ fluids at PACMANUS/NE Pual also show evidence for anhydrite dissolution and water-rock interaction (fixation of B) subsequent to seawater entrainment. Hence, the evolution of fluid compositions at Pual Ridge reflects the cumulative effects of water/rock interaction, admixing and reaction of fluids exsolved from silicic magma, phase separation/segregation and seawater ingress into upflow zones.

(C) 2010 Elsevier Ltd. All rights reserved.

\section{INTRODUCTION}

Hydrothermal systems situated in back-arc basins share many common physical and chemical processes with their mid-ocean ridge (MOR) counterparts, including waterrock reaction, magmatic volatile degassing, phase separation and subsurface mixing of fluids. In back-arc systems, however, the proximity to a subduction zone and eruption of magmas with higher water contents relative to mid-ocean ridge basalt (MORB) results in a broader range of degassed volatiles capable of influencing hydrothermal fluid chemistry (de Ronde, 1995; Ishibashi and Urabe, 1995; Yang and Scott, 2006). In contrast to MOR settings, where $\mathrm{CO}_{2}$ is the dominant volatile degassed, the exsolution of large quantities of $\mathrm{H}_{2} \mathrm{O}$ and $\mathrm{CO}_{2}$ from silicic magmas can be accompanied by acid-volatile species such as $\mathrm{SO}_{2}, \mathrm{HCl}$ and $\mathrm{HF}$. Subsequent entrainment of water-rich magmatic fluids into existing hydrothermal circulation cells could substantially lower $\mathrm{pH}$, thereby influencing the transport of dissolved metals and styles of crustal alteration (Gamo et al., 1997, 2006; Gena et al., 2001; Yang and Scott, 2006). Moreover, magmatic fluids have long been proposed as an additional source of economically important metals (i.e. $\mathrm{Cu}, \mathrm{Zn}, \mathrm{Ag}$ and $\mathrm{Au}$ ) in excess of that feasible by rock leaching alone (Yang and Scott, 1996, 2006; Sun et al., 2004; Simmons and Brown, 2006). Many large volcanic-hosted massive sulfide deposits (Kuroko-type) are thought to have formed in arc and back-arc magmatic-hydrothermal settings (Franklin et al., 1981; Herzig and Hannington, 1995). Thus, models for the formation of metal sulfide deposits in back-arc environments require an understanding of the role of magmatic fluids in metal transport and deposition.

Discharge of magmatic fluids directly into the water column has been observed above submarine arc volcanoes (Embley et al., 2006; Nakagawa et al., 2006; Lupton et al., 2008) and seamounts (Cheminée et al., 1991; Gamo et al., 1993; de Ronde et al., 2005; Resing et al., 2007, 2009), and contributions of magmatic acid-volatile species and water to hydrothermal fluids have been reported in a few locations (Sedwick et al., 1992; McMurtry et al., 1993; Gamo et al., 1997; Zengqian et al., 2005; Nakagawa et al., 2006). In general, however, vent fluids from active magmatic-hydrothermal systems hosted in felsic crust have been historically under-sampled despite the prevalence of hydrothermal activity associated with back-arc volcanism in the western Pacific (Ishibashi and Urabe, 1995). Consequently, factors influencing the formation of vent fluid compositions in these environments are poorly constrained.

In 1999 the Ocean Drilling Program (ODP) drilled into an active felsic-hosted hydrothermal system at the PACM-
ANUS site in the Eastern Manus Volcanic Zone, Papua New Guinea (Figs. 1 and 2). Subsequent investigations of alteration assemblages recovered in drill-cores indicated a
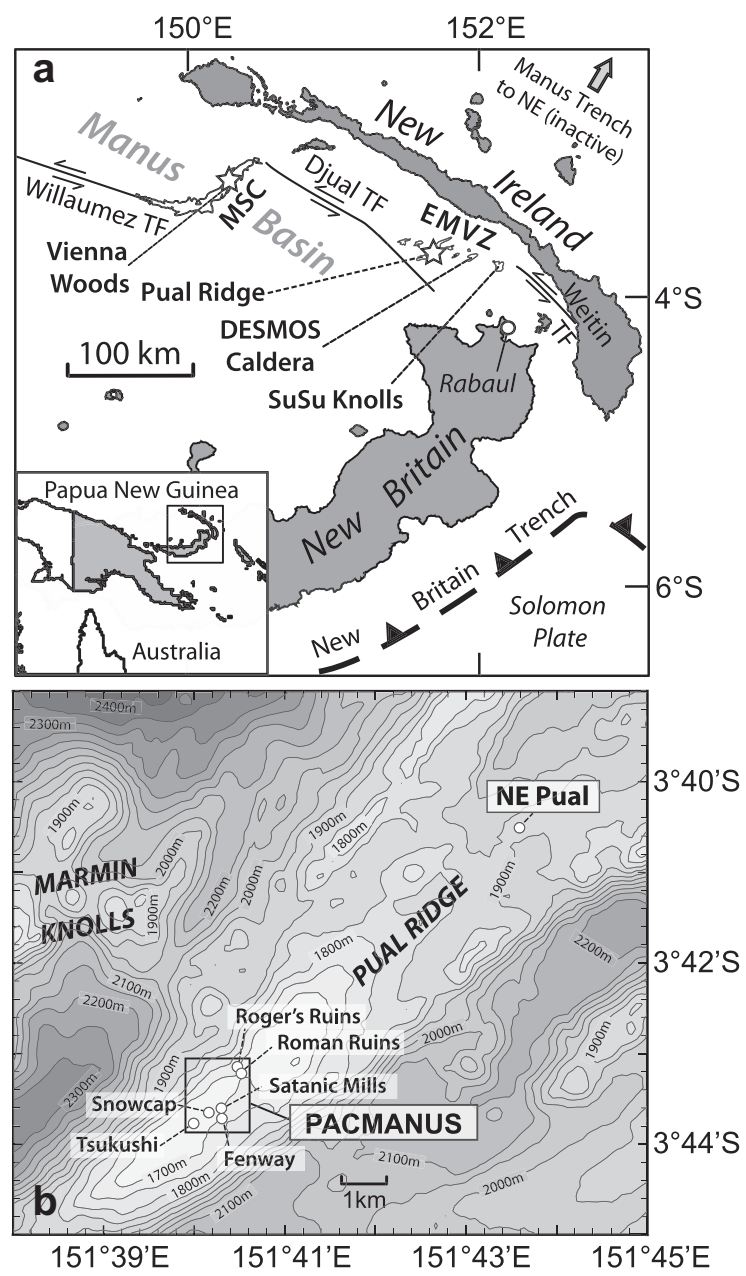

Fig. 1. (a) Regional map showing a portion of the Bismarck Archipelago (Papua New Guinea, in gray), the Manus Basin and the locations of seafloor features (white with black outlines) such as the Manus Spreading Center (MSC), Eastern Manus Volcanic Zone (EMVZ), transform faults (TF) and known sites of seafloor hydrothermal activity. Vienna Woods and Pual Ridge are shown as stars. The active New Britain subduction zone is shown to the southeast of the archipelago, while the inactive Manus Trench (not shown) is to the northeast. (b) SeaBeam bathymetric map of Pual Ridge and nearby Marmin Knolls neovolcanic edifices showing locations of the PACMANUS and Northeast (NE) Pual vent fields. Individual areas of venting within PACMANUS are shown. (Adapted from Tivey et al., 2006.) 
a

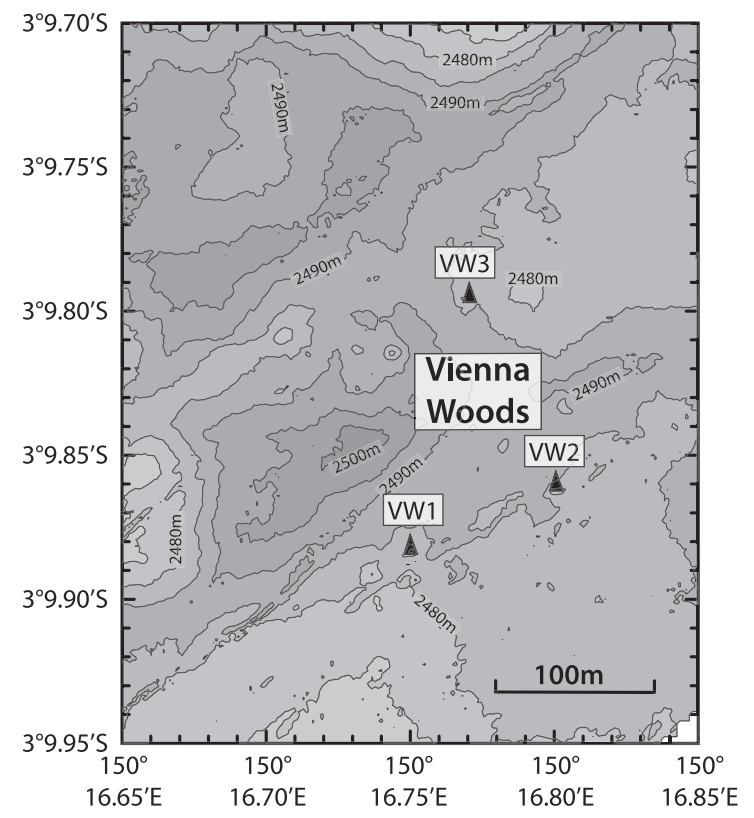

b

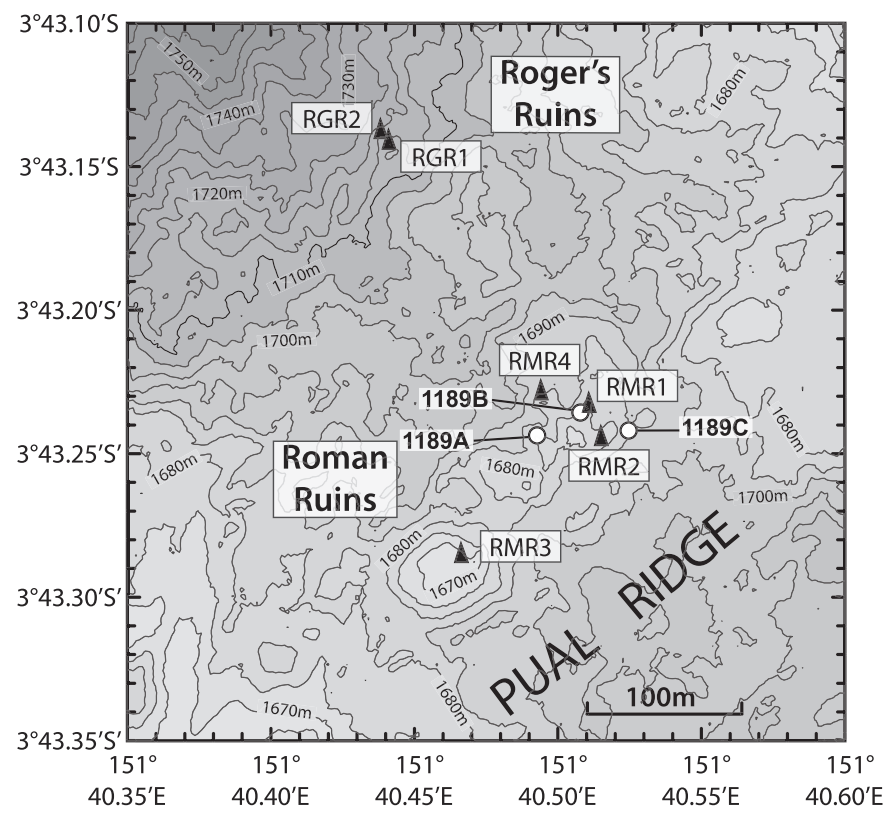

C

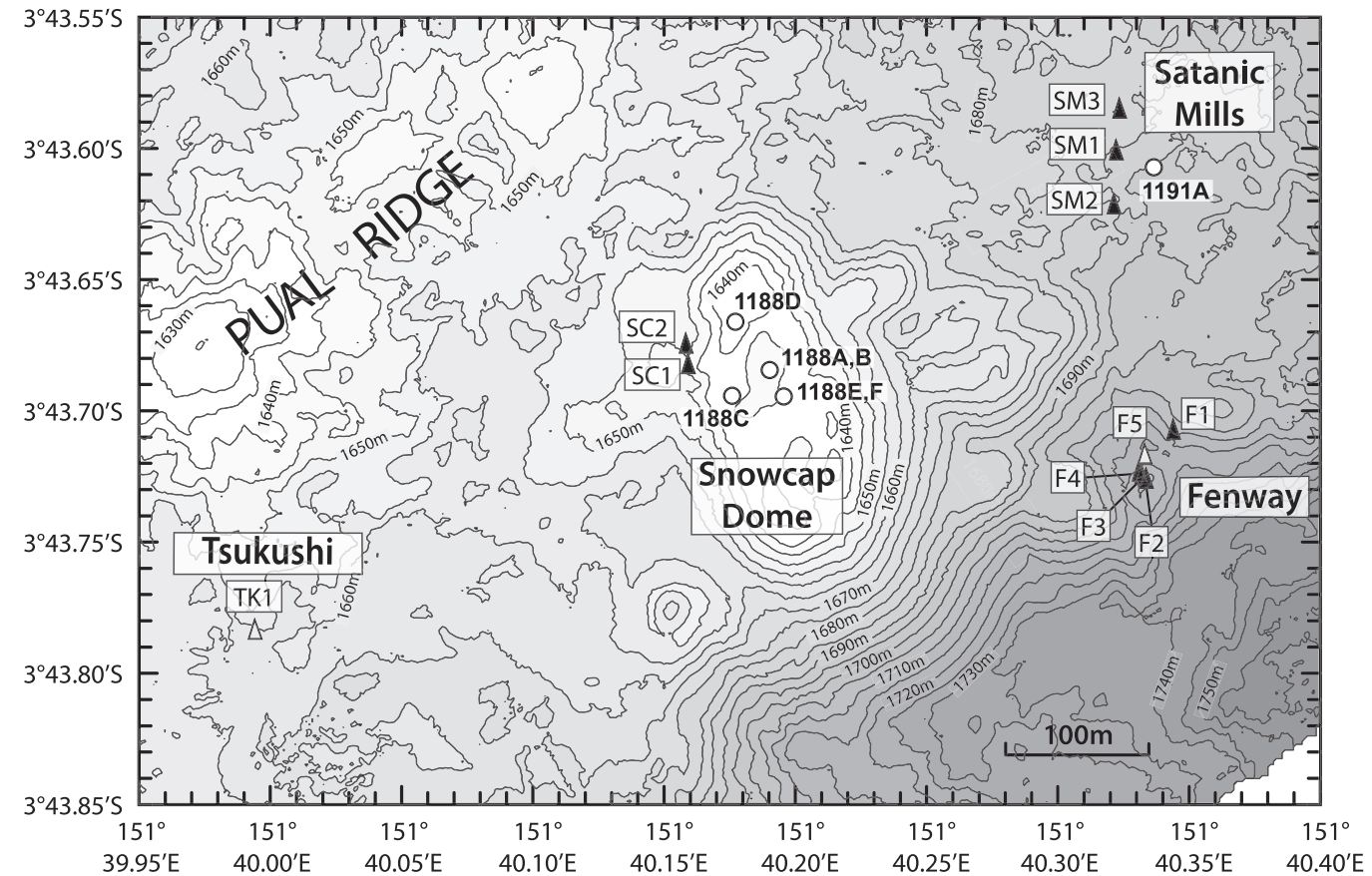

Fig. 2. SM2000 bathymetry of the Vienna Woods hydrothermal field (a) and the northern (b) and southern (c) portions of the PACMANUS hydrothermal field (adapted from Tivey et al., 2006). Sampled vents are denoted by solid triangles (moderate to high temperature focused flow), or open triangles (low temperature $\left(<80^{\circ} \mathrm{C}\right)$ vents). Each discrete vent is given an identifier abbreviating the vent area (VW, Vienna Woods; RMR, Roman Ruins; RGR, Roger's Ruins; SM, Satanic Mills; SC, Snowcap; TK, Tsukushi; F, Fenway). Locations of the ODP Leg 193 drillholes (Sites 1188, 1189 and 1191, from Binns et al., 2007) are shown as open circles.

complex system affected by both temporally variable magmatic acid-volatile inputs and subsurface mixing of hydrothermal fluids with seawater (Bach et al., 2003; Roberts et al., 2003; Lackschewitz et al., 2004; Paulick et al., 2004; Paulick and Bach, 2006; Binns et al., 2007). In addition to magmatic inputs, pervasive entrainment and mixing of seawater in the subsurface, as indicated previously by
ODP Leg 193, may also therefore be an important process that influences vent fluid chemistry in back-arc hydrothermal systems.

In 2006 we conducted a detailed chemical and isotopic survey of vent fluid compositions at the near-arc hydrothermal fields PACMANUS and Northeast Pual (both located on Pual Ridge near the New Britain Arc), and the 
basalt-hosted Vienna Woods field (located farther from the arc on the Manus Spreading Center) to examine the effects of variable magmatic fluid inputs and crustal composition (both related to arc proximity) on vent fluid geochemistry. Here, we demonstrate that hydrothermal fluids at Pual Ridge have undergone a complex evolution involving multiple consecutive or concurrent processes. Fluids there are heavily influenced by variable inputs of acidic magmatic solutions to seawater-derived vent fluids at depth within the hydrothermal reservoir, in addition to water/rock reaction with felsic crust. Furthermore, phase separation/segregation effects and widespread admixing of seawater prior to venting at Pual Ridge subsequently modifies the compositions of resulting fluid mixtures and partially obscures the effects of magmatic inputs, further complicating fluid histories. In contrast, the geochemistry of vent fluids at Vienna Woods is similar in many respects to other temporally stable hydrothermal systems commonly sampled in MOR settings. This study demonstrates that the indirect effects of arc proximity can exert substantial influence on the evolution of hydrothermal fluid compositions in back-arc environments and adds to the diversity of known processes influencing vent fluid geochemistry.

\section{GEOLOGIC SETTING}

The Manus Basin is a young (ca. 3.5 Ma old), rapidly opening (up to $137 \mathrm{~mm} /$ year, Tregoning, 2002) back-arc ba$\sin$ in the northeastern portion of the Bismarck Sea (Fig. 1a), tectonically bordered to the north by the presently inactive Manus Trench and to the south by the Willaumez Rise and the active New Britain Trench (Taylor, 1979a; Taylor et al., 1994; Lee and Ruellan, 2006). Volcanism associated with basin extension occurs along a series of spreading centers and rifts between three major transform faults (Taylor, 1979a; Taylor et al., 1994; Martinez and Taylor, 1996). In the center of the basin, approximately $250 \mathrm{~km}$ from the active New Britain Arc, spreading occurs along the $120 \mathrm{~km}$ long Manus Spreading Center (MSC) bounded by the Willaumez and Djual transform faults (Fig. 1a). Predominantly MORB-like basaltic lavas erupt along the MSC (Sinton et al., 2003) and numerous areas of hydrothermal activity have been reported, the largest of which is the unsedimented Vienna Woods field (Both et al., 1986; Tufar, 1990; Lisitsyn et al., 1993). In contrast, the eastern Manus Basin between the Djual and Weitin transform faults is an extensional transform zone within remnant Eocene-Oligocene island-arc crust formed during previous southwestward subduction along the Manus Trench (Binns and Scott, 1993; Binns et al., 2007). As such, it is probably the precursor of a back-arc spreading center like the MSC. Volcanism associated with the incipient rifting of pre-existing intermediate/felsic crust has produced a complex series of en echelon neovolcanic ridges (such as Pual Ridge shown in Fig. 1b) and volcanic domes on the seafloor known as the Eastern Manus Volcanic Zone (EMVZ, Fig. 1a). Lavas erupted in these edifices vary progressively from basaltic to more evolved rhyodacitic compositions (Binns and Scott, 1993; Kamenetsky et al., 2001; Sinton et al., 2003) and they possess isotopic, major and trace element characteristics similar to subaerial volcanoes of the New Britain Arc, indicating strong arc affinities (Sinton et al., 2003; Pearce and Stern, 2006). Due to its proximity to the New Britain Arc $(<100 \mathrm{~km})$, the relative influences of the mantle wedge, subducting slab and remnant arc crust on EMVZ melt production and volcanism are complex (Sinton et al., 2003; Pearce and Stern, 2006). Several large areas of hydrothermal activity have been discovered in the EMVZ (Fig. 1a) in the last two decades. These include the DESMOS (Gamo et al., 1993, 1997, 2006; Auzende et al., 1997) and SuSu Knolls (Binns et al., 1997; Auzende et al., 2000; Moss and Scott, 2001; Tivey et al., 2006; Hrischeva et al., 2007) volcanic domes, and the PACMANUS hydrothermal field (Binns and Scott, 1993; Auzende et al., 1997).

\subsection{Hydrothermal vent fields}

\subsubsection{Vienna Woods}

The Vienna Woods field was discovered and documented in 1990 (Tufar, 1990; Lisitsyn et al., 1993) and hydrothermal fluids were subsequently sampled between 1995 and 2000 (Auzende et al., 1996; Gamo et al., 1996a,b, 1997; Ishibashi et al., 1996; Douville et al., 1999a,b; Fourre et al., 2006). Though the site is hosted in basalt that is compositionally similar to MORB, lavas along the MSC are variable and more intermediate compositions occur to the south and north of Vienna Woods (Shaw et al., 2004). The rift zone itself is comprised of basaltic pillow lavas/sheet flows with minimal sediment cover and occasional 1-2 $\mathrm{m}$ wide along-axis fissures. Hydrothermal activity in 2006 was confined to an area of approximately $100 \mathrm{~m}$ by $150 \mathrm{~m}$ (Fig. 2a) at a water depth of $2470 \mathrm{~m}$ within the rift zone of the MSC $(\sim 0.5 \mathrm{~km}$ south of the neovolcanic zone). Three main clusters of tall sulfide structures (5-12 m high), each separated by 100-150 $\mathrm{m}$ and generally located near fissures, were actively venting relatively clear fluids with little visible precipitate upon mixing with seawater.

\subsubsection{PACMANUS and Northeast Pual}

The PACMANUS (Papua New Guinea-AustraliaCanada-MANUS) vent field, originally discovered during the 1991 expedition of the same name, consists of several discrete vent areas distributed over a $1.5 \mathrm{~km}$ section of Pual Ridge (Fig. 1b, Binns and Scott, 1993). Pual Ridge is a 20 $\mathrm{km}$ long, Y-shaped neovolcanic edifice located $80 \mathrm{~km}$ from Rabaul Volcano on the New Britain Arc (Fig. 1b). With a ridge crest at $1600-1700 \mathrm{~m}$ depth, it is $1-1.5 \mathrm{~km}$ in width and stands $\sim 500 \mathrm{~m}$ above the sedimented basaltic to andesitic seafloor of the EMVZ (Binns et al., 2007). Erupted lavas consist of highly vesicular and blocky dacite/ rhyodacite with some rhyolite and the ridge itself is constructed of stacked, subhorizontal flows up to $30 \mathrm{~m}$ thick with negligible to minor sediment cover (Binns and Scott, 1993; Paulick et al., 2004; Yang and Scott, 2005). Based on the composition of erupted lavas, Yang and Scott (2002) proposed that the entire ridge represents a single calc-alkaline trend that may have been generated by fractional crystallization of a single volatile-rich mafic magma 
Table 1

Measured compositions of vent fluid samples from the Vienna Woods, PACMANUS and NE Pual vent fields, Manus Basin.

\begin{tabular}{|c|c|c|c|c|c|c|c|c|c|c|c|c|c|c|}
\hline $\begin{array}{l}\text { Vent field } \\
\text { Area: } \operatorname{VENT}^{\mathrm{a}}\left(T_{\max }\right)\end{array}$ & Sample $^{\mathrm{b}}$ & $\begin{array}{l}\mathrm{Mg} \\
(\mathrm{mm})\end{array}$ & $\begin{array}{l}\mathrm{pH} \\
\left(25^{\circ} \mathrm{C}\right)\end{array}$ & $\begin{array}{l}\mathrm{Na} \\
(\mathrm{mm})\end{array}$ & $\begin{array}{l}\mathrm{Cl} \\
(\mathrm{mm})\end{array}$ & $\begin{array}{l}\mathrm{Ca} \\
(\mathrm{mm})\end{array}$ & $\begin{array}{l}\mathrm{K} \\
(\mathrm{mm})\end{array}$ & $\begin{array}{l}\mathrm{SiO}_{2} \\
(\mathrm{~mm})\end{array}$ & $\begin{array}{l}\mathrm{SO}_{4}{ }^{2-} \\
(\mathrm{mm})\end{array}$ & $\begin{array}{l}\mathrm{Br} \\
(\mathrm{mm})\end{array}$ & $\begin{array}{l}\mathrm{F} \\
(\mathrm{mm})\end{array}$ & $\begin{array}{l}\mathrm{Fe} \\
(\mathrm{mm})\end{array}$ & $\begin{array}{l}\mathrm{Mn} \\
(\mathrm{mm})\end{array}$ & $\begin{array}{l}\mathrm{Li} \\
(\mathrm{mm}) \\
\end{array}$ \\
\hline \multicolumn{15}{|l|}{ Vienna Woods } \\
\hline \multirow{2}{*}{ VW1 $\left(282^{\circ} \mathrm{C}\right)$} & J2-207-IGT7 & 3.36 & 4.8 & 520 & 694 & 76.6 & 20.6 & 14.3 & 1.88 & 1.03 & 0.023 & 0.148 & 0.328 & 1.02 \\
\hline & $\mathrm{J} 2-207-\mathrm{M} 2$ & 1.44 & 4.9 & 506 & 677 & 77.3 & 20.7 & - & - & 1.05 & 0.022 & 0.141 & 0.341 & 1.03 \\
\hline VW2 $\left(273^{\circ} \mathrm{C}\right)$ & J2-207-IGT4 & 1.02 & 4.2 & 509 & 687 & 79.5 & 21.0 & 14.7 & 0.72 & 1.05 & 0.021 & 0.162 & 0.358 & 1.14 \\
\hline \multirow[t]{2}{*}{ VW3 $\left(285^{\circ} \mathrm{C}\right)$} & J2-207-IGT8 & 1.11 & 4.7 & 504 & 663 & 69.5 & 20.0 & 14.4 & 0.87 & 1.01 & 0.019 & 0.127 & 0.207 & 1.06 \\
\hline & $\mathrm{J}^{2-207-\mathrm{IGT}^{+}}{ }^{+}$ & 14.9 & 5.4 & 494 & 644 & 53.5 & 17.2 & 10.4 & 7.83 & 0.971 & 0.034 & 0.082 & 0.151 & 0.759 \\
\hline \multicolumn{15}{|l|}{ PACMANUS } \\
\hline \multicolumn{15}{|l|}{ Roman Ruins } \\
\hline \multirow[t]{3}{*}{$\operatorname{RMR} 1\left(314^{\circ} \mathrm{C}\right)$} & J2-208-IGT8 & 7.26 & 2.3 & 470 & 617 & 18.4 & 71.8 & 13.7 & 0.47 & 0.924 & 0.120 & 5.56 & 3.40 & 0.986 \\
\hline & J2-208-IGT5 & 7.59 & 2.4 & 485 & 619 & 18.6 & 71.3 & 13.4 & 0.64 & 0.923 & 0.120 & 5.62 & 3.28 & 0.957 \\
\hline & $\mathrm{J} 2-208-\mathrm{M} 4$ & 8.19 & 2.4 & 472 & 621 & 18.3 & 70.4 & - & - & 0.932 & 0.134 & 5.53 & 3.49 & 0.968 \\
\hline \multirow[t]{3}{*}{$\operatorname{RMR} 2\left(272{ }^{\circ} \mathrm{C}\right)$} & J2-208-IGT2 & 15.9 & 2.3 & 434 & 549 & 10.6 & 50.6 & 16.6 & 2.61 & 0.808 & 0.097 & - & 2.26 & 0.620 \\
\hline & J2-208-IGT1 & 16.0 & 2.4 & 435 & 543 & 10.3 & 50.5 & 16.7 & 2.54 & 0.812 & 0.096 & 0.991 & 2.27 & 0.639 \\
\hline & J2-208-M2 & 27.0 & 2.7 & 443 & 551 & 10.5 & 38.5 & - & - & 0.784 & 0.091 & 0.681 & 1.70 & 0.453 \\
\hline \multirow[t]{2}{*}{$\operatorname{RMR} 3\left(278^{\circ} \mathrm{C}\right)$} & $\mathrm{J} 2-213-\mathrm{IGT}^{+}$ & 22.7 & 3.2 & 508 & 648 & 18.8 & 58.8 & 11.6 & 10.6 & 0.993 & 0.117 & 4.32 & 2.58 & 0.778 \\
\hline & J2-213-M4 & 6.39 & 2.5 & 534 & 708 & 23.8 & 86.4 & - & - & 1.09 & 0.157 & 6.85 & 4.28 & 1.16 \\
\hline & $\mathrm{J} 2-222-\mathrm{M} 4$ & 4.71 & 2.6 & 495 & 647 & 21.8 & 75.5 & 17.3 & - & 1.04 & 0.125 & 6.17 & 2.73 & 0.948 \\
\hline Roger's Ruins & & & & & & & & & & & & & & \\
\hline $\operatorname{RGR} 1\left(320^{\circ} \mathrm{C}\right)$ & J2-213-IGT3 & 5.09 & 2.7 & 484 & 635 & 25.7 & 74.5 & 16.98 & 1.11 & 0.975 & 0.143 & 4.09 & 2.41 & 0.788 \\
\hline & J2-213-IGT4 & 7.61 & 2.7 & 487 & 634 & 24.2 & 70.1 & 16.15 & 2.59 & 0.968 & 0.146 & 3.89 & 2.30 & 0.765 \\
\hline & $\mathrm{J} 2-213-\mathrm{M} 2$ & 4.24 & 2.7 & 489 & 641 & 25.9 & 75.6 & - & - & 0.991 & 0.155 & 4.43 & 2.68 & 0.832 \\
\hline $\operatorname{RGR} 2\left(274^{\circ} \mathrm{C}\right)$ & $\mathrm{J}_{2-222-\mathrm{IGT}_{4}}{ }^{+}$ & 22.3 & 3.0 & 479 & 606 & 18.3 & 49.9 & 11.0 & 9.58 & 0.919 & 0.113 & 2.130 & 1.45 & 0.498 \\
\hline & J2-222-IGT3 & 8.96 & 2.6 & 481 & 631 & 22.4 & 68.6 & 15.8 & 1.50 & 0.969 & 0.128 & 3.173 & 2.15 & 0.753 \\
\hline & $\mathrm{J} 2-222-\mathrm{M} 2$ & 8.61 & 2.6 & 484 & 631 & 22.4 & 68.8 & 15.8 & - & 0.975 & 0.140 & 3.355 & 2.17 & 0.775 \\
\hline Satanic Mills & & & & & & & & & & & & & & \\
\hline $\mathrm{SM} 1\left(295^{\circ} \mathrm{C}\right)$ & J2-209-IGT6 & 9.84 & 2.7 & 411 & 523 & 12.5 & 58.2 & 11.8 & 2.69 & 0.805 & 0.160 & 2.74 & 2.05 & 0.641 \\
\hline & J2-209-IGT7 & 8.95 & 2.7 & 409 & 521 & 12.5 & 59.3 & 12.0 & 2.18 & 0.799 & 0.162 & 2.79 & 2.14 & 0.638 \\
\hline & $\mathrm{J} 2-209-\mathrm{M} 4$ & 8.16 & 2.6 & 407 & 519 & 12.3 & 60.4 & - & - & 0.797 & 0.175 & 2.97 & 2.34 & 0.646 \\
\hline $\mathrm{SM} 2\left(241^{\circ} \mathrm{C}\right)$ & J2-209-IGT4 ${ }^{+}$ & 26.6 & 2.7 & 400 & 478 & 7.07 & 31.0 & 9.40 & 12.1 & 0.715 & 0.215 & 0.705 & 1.11 & 0.311 \\
\hline & $\mathrm{J} 2-209-\mathrm{M} 2$ & 16.9 & 2.4 & 374 & 455 & 5.87 & 38.6 & - & - & 0.691 & 0.287 & 1.12 & 1.68 & 0.441 \\
\hline SM3 $\left(288^{\circ} \mathrm{C}\right)$ & J2-214-IGT8 & 9.73 & 2.5 & 403 & 510 & 13.1 & 58.1 & 12.3 & 2.49 & 0.763 & 0.197 & 0.982 & 1.82 & 0.601 \\
\hline & J2-214-IGT5 & 9.81 & 2.5 & 402 & 510 & 13.1 & 56.4 & 12.2 & 2.35 & 0.772 & 0.203 & 0.958 & 1.82 & 0.587 \\
\hline & J2-214-M4 & 9.72 & - & 403 & 511 & 13.1 & 57.0 & - & - & 0.787 & 0.207 & 1.04 & 1.99 & 0.600 \\
\hline & $\mathrm{J}_{2}-210-\mathrm{IGT}^{+}$ & 48.5 & 5.0 & 450 & 532 & 9.71 & 12.9 & 1.69 & 24.1 & 0.809 & 0.078 & - & 0.212 & 0.089 \\
\hline & $\mathrm{J} 2-210-\mathrm{M} 2$ & 31.5 & 4.7 & 420 & 501 & 6.57 & 24.8 & - & - & 0.749 & 0.126 & 0.032 & 1.07 & 0.313 \\
\hline $\mathrm{SC} 2\left(180^{\circ} \mathrm{C}\right)$ & J2-211-IGT4 & 24.2 & 3.4 & 440 & 532 & 6.80 & 34.7 & 9.45 & 5.18 & 0.816 & 0.170 & 0.141 & 1.63 & 0.486 \\
\hline & J2-211-IGT3 & 24.8 & 3.7 & 437 & 536 & 6.79 & 34.0 & 9.28 & 5.73 & 0.825 & 0.160 & 0.169 & 1.55 & 0.476 \\
\hline & $\mathrm{J} 2-211-\mathrm{M} 4$ & 24.5 & 3.4 & 435 & 530 & 6.59 & 34.4 & - & - & 0.820 & 0.173 & 0.129 & 1.64 & 0.503 \\
\hline Tsukushi & & & & & & & & & & & & & & \\
\hline $\operatorname{TK} 1\left(62^{\circ} \mathrm{C}\right)$ & J2-211-IGT7 & 44.4 & 5.9 & 477 & 572 & 12.5 & 20.7 & 3.55 & 18.2 & 0.883 & 0.077 & 0.124 & 0.570 & 0.219 \\
\hline & J2-214-IGT2 & 45.2 & 5.8 & 477 & 570 & 12.3 & 19.8 & 3.24 & 22.6 & 0.869 & 0.077 & - & 0.558 & 0.209 \\
\hline & $\mathrm{J} 2-214-\mathrm{M} 2$ & 44.8 & 5.7 & 473 & 570 & 12.5 & 20.0 & - & - & 0.874 & 0.077 & 0.117 & 0.574 & 0.219 \\
\hline Fenway & & & & & & & & & & & & & & \\
\hline $\mathrm{F} 1\left(329^{\circ} \mathrm{C}\right)$ & J2-210-IGT1 & 5.97 & 2.5 & 347 & 463 & 14.3 & 53.8 & 12.7 & 0.93 & 0.717 & 0.279 & 7.37 & 2.31 & 0.637 \\
\hline & J2-210-M4 & 5.84 & 2.6 & 340 & 465 & 14.3 & 53.8 & - & - & 0.714 & 0.291 & 7.56 & 2.56 & 0.654 \\
\hline & $\mathrm{J}_{2-214-\mathrm{IGT1}^{+}}$ & 39.8 & 4.5 & 422 & 520 & 11.3 & 21.2 & 3.69 & 20.3 & 0.796 & 0.121 & 2.03 & 0.658 & 0.198 \\
\hline $\mathrm{F} 2\left(343^{\circ} \mathrm{C}\right)$ & J2-212-IGT8 & 4.90 & 2.7 & 485 & 683 & 25.2 & 86.4 & 13.8 & 0.55 & 1.08 & 0.168 & 13.3 & 4.22 & 1.03 \\
\hline & J2-212-IGT5 & 5.26 & 2.7 & 485 & 685 & 25.2 & 85.8 & 13.8 & 0.74 & 1.07 & 0.169 & 13.1 & 4.16 & 1.03 \\
\hline & $\mathrm{J} 2-212-\mathrm{M} 4$ & 4.66 & 2.7 & 483 & 685 & 25.7 & 86.8 & - & - & 1.08 & 0.173 & 13.4 & 4.54 & 1.07 \\
\hline $\mathrm{F}^{*}{ }^{*}\left(358^{\circ} \mathrm{C}\right)$ & J2-212-IGT2 & 4.52 & 2.7 & 417 & 589 & 22.2 & 73.9 & 11.9 & 0.97 & 0.919 & 0.165 & 11.5 & 3.60 & 0.904 \\
\hline & J2-212-IGT1 & 4.74 & 2.8 & 377 & 517 & 20.3 & 64.9 & 10.4 & 2.45 & 0.796 & 0.154 & 9.83 & 3.09 & 0.748 \\
\hline & $\mathrm{J} 2-212-\mathrm{M} 2$ & 8.89 & 2.8 & 425 & 573 & 20.4 & 66.8 & - & - & 0.910 & 0.160 & 9.97 & 3.42 & 0.793 \\
\hline $\mathrm{F} 4\left(284^{\circ} \mathrm{C}\right)$ & J2-216-IGT7 & 8.95 & 2.6 & 395 & 527 & 17.7 & 60.2 & 10.9 & 2.46 & 0.826 & 0.158 & 6.85 & 2.95 & 0.713 \\
\hline & J2-216-IGT6 & 8.69 & 2.5 & 392 & 524 & 17.7 & 60.7 & 11.3 & 2.17 & 0.834 & 0.155 & 6.65 & 2.94 & 0.685 \\
\hline & $\mathrm{J} 2-216-\mathrm{M} 2$ & 10.2 & 2.4 & 394 & 527 & 17.4 & 58.2 & - & - & 0.816 & 0.158 & 6.88 & 3.05 & 0.688 \\
\hline $\mathrm{F} 5\left(80^{\circ} \mathrm{C}\right)$ & J2-216-IGT4 & 45.0 & 5.0 & 437 & 517 & 13.3 & 14.1 & 1.72 & 27.6 & 0.792 & 0.082 & 0.868 & 0.325 & 0.109 \\
\hline & J2-216-IGT3 & 44.0 & 4.9 & 436 & 517 & 14.1 & 15.3 & 1.90 & 27.4 & 0.797 & 0.082 & 0.572 & 0.368 & 0.119 \\
\hline & $\mathrm{J} 2-216-\mathrm{M} 4$ & 48.8 & 5.8 & 453 & 535 & 11.8 & 11.7 & - & - & 0.822 & 0.069 & 0.172 & 0.157 & 0.065 \\
\hline NE Pual & & & & & & & & & & & & & & \\
\hline $\mathrm{NP} 1\left(35^{\circ} \mathrm{C}\right)$ & J2-218-IGT3 & 50.6 & 6.9 & 466 & 536 & 12.9 & 10.5 & 0.926 & 30.0 & 0.807 & 0.071 & 0.105 & 0.199 & 0.044 \\
\hline & J2-218-IGT4 & 49.9 & 6.9 & 461 & 535 & 14.1 & 10.8 & 1.19 & 29.5 & 0.795 & 0.071 & 0.062 & 0.135 & 0.046 \\
\hline & J2-218-M4 & 50.3 & 6.9 & 454 & 535 & 13.5 & 10.7 & - & - & 0.797 & 0.069 & 0.174 & 0.210 & 0.049 \\
\hline Bottom SW $\left(3^{\circ} \mathrm{C}\right)$ & & 52.4 & 7.9 & 471 & 540 & 10.5 & 9.87 & $0.13^{\mathrm{c}}$ & 28.2 & 0.808 & 0.064 & 0.0 & 0.0 & 0.028 \\
\hline
\end{tabular}


Table 1 (continued)

\begin{tabular}{|c|c|c|c|c|c|c|c|c|c|c|c|c|c|c|c|c|c|}
\hline $\begin{array}{l}\text { Vent field } \\
\text { Area: } \operatorname{VENT}^{\mathrm{a}}\left(T_{\max }\right)\end{array}$ & $\begin{array}{l}\text { B } \\
(\mathrm{mm})\end{array}$ & $\begin{array}{l}\mathrm{Sr} \\
(\mu \mathrm{m})\end{array}$ & $\begin{array}{l}\mathrm{Rb} \\
(\mu \mathrm{m})\end{array}$ & $\begin{array}{l}\mathrm{Cs} \\
(\mu \mathrm{m})\end{array}$ & $\begin{array}{l}\mathrm{Al} \\
(\mu \mathrm{m})\end{array}$ & $\begin{array}{l}\Sigma \mathrm{H}_{2} \mathrm{~S} \\
(\mathrm{mM}) \\
\end{array}$ & $\begin{array}{l}\mathrm{H}_{2} \\
(\mu \mathrm{M}) \\
\end{array}$ & $\begin{array}{l}\mathrm{CH}_{4} \\
(\mu \mathrm{M}) \\
\end{array}$ & $\begin{array}{l}\mathrm{CO} \\
(\mu \mathrm{M}) \\
\end{array}$ & $\begin{array}{l}\Sigma \mathrm{CO}_{2} \\
(\mathrm{~mm})\end{array}$ & $\begin{array}{l}\delta^{13} \mathrm{C}_{\mathrm{CO}_{2}} \\
(\%)\end{array}$ & $\begin{array}{l}\delta^{13} \mathrm{C}_{\mathrm{CH}_{4}} \\
(\% \mathrm{\%}) \\
\end{array}$ & $\begin{array}{l}\delta \mathrm{D}_{\mathrm{H}_{2} \mathrm{O}} \\
(\%)\end{array}$ & $\begin{array}{l}\delta^{18} \mathrm{O}_{\mathrm{H}_{2} \mathrm{O}} \\
(\%)\end{array}$ & $\begin{array}{l}\delta^{34} \mathrm{~S}_{\mathrm{SO}_{4}} \\
(\%)\end{array}$ & $\begin{array}{l}\delta^{34} \mathrm{~S}_{\mathrm{H}_{2} \mathrm{~S}} \\
(\%)\end{array}$ & ${ }^{87} \mathrm{Sr} /{ }^{86} \mathrm{Sr}$ \\
\hline \multicolumn{18}{|l|}{ Vienna Woods } \\
\hline \multirow[t]{3}{*}{$\mathrm{VW} 1\left(282^{\circ} \mathrm{C}\right)$} & 0.240 & 232 & 15.8 & 0.267 & 5.5 & 1.3 & 42 & 65 & - & 4.36 & -5.7 & -20.8 & 2.1 & 0.50 & - & - & - \\
\hline & 0.250 & 240 & 17.5 & 0.283 & 6.2 & 1.5 & 39 & 61 & - & 4.21 & -4.8 & -20.7 & 2.6 & 0.55 & - & - & 0.70440 \\
\hline & - & 236 & 19.4 & 0.288 & 7.2 & - & - & - & - & - & - & - & - & - & - & - & - \\
\hline VW2 $\left(273^{\circ} \mathrm{C}\right)$ & 0.250 & 244 & 18.1 & 0.281 & 7.3 & 1.6 & 55 & 70 & - & 4.39 & -5.1 & -20.7 & 2.5 & - & - & - & - \\
\hline \multirow[t]{2}{*}{ VW3 $\left(285^{\circ} \mathrm{C}\right)$} & 0.240 & 224 & 16.6 & 0.256 & 6.7 & 1.5 & 43 & 62 & - & 4.47 & -5.6 & -20.8 & 0.28 & 0.40 & - & - & - \\
\hline & 0.185 & 183 & 13.0 & 0.188 & 5.1 & 1.0 & 32 & 46 & - & 3.80 & - & - & 2.3 & 0.41 & 20.6 & - & - \\
\hline \multicolumn{18}{|l|}{ PACMANUS } \\
\hline \multicolumn{18}{|l|}{ Roman Ruins } \\
\hline \multirow[t]{3}{*}{$\operatorname{RMR} 1\left(314{ }^{\circ} \mathrm{C}\right)$} & 1.85 & 78.4 & 63.8 & 2.23 & 8.9 & 6.4 & 65 & 27 & 0.043 & 15.3 & -3.3 & -13.4 & - & - & - & 0.87 & - \\
\hline & 1.82 & 80.1 & 62.6 & 2.24 & 7.1 & 6.5 & 66 & 27 & 0.047 & 15.3 & - & - & -0.38 & 1.0 & - & 1.9 & - \\
\hline & - & 76.9 & 67.2 & 2.42 & - & - & - & - & - & - & - & - & - & - & - & - & - \\
\hline $\operatorname{RMR} 2\left(272{ }^{\circ} \mathrm{C}\right)$ & 1.34 & 62.0 & 42.3 & 1.57 & 5.6 & 2.7 & 29 & 36 & - & 19.1 & -3.0 & -13.3 & -3.1 & 0.94 & 20.6 & - & - \\
\hline & 1.34 & 61.0 & 41.2 & 1.50 & 4.7 & 2.9 & 29 & 35 & 0.023 & 19.2 & - & - & -1.5 & 1.1 & 20.6 & 2.8 & - \\
\hline & - & 71.3 & 33.9 & 1.16 & 4.1 & - & - & - & - & - & - & - & - & - & - & - & - \\
\hline $\operatorname{RMR} 3\left(278^{\circ} \mathrm{C}\right)$ & 1.42 & 85.1 & 48.8 & 1.69 & 4.6 & 2.5 & 72 & 8.2 & 0.023 & 6.72 & - & - & -2.6 & 0.82 & 20.7 & 2.1 & - \\
\hline & - & 85.7 & 80.9 & 2.85 & 15 & - & - & - & - & - & - & - & - & - & - & - & - \\
\hline RMR4 $\left(341^{\circ} \mathrm{C}\right)$ & 1.62 & 88.0 & 74.5 & 2.23 & 6.5 & 6.3 & 53 & 22 & - & 9.54 & -4.0 & - & -2.5 & 1.0 & - & 0.0 & 0.70460 \\
\hline & 1.57 & 86.5 & 71.5 & 2.26 & 5.1 & - & - & - & - & - & - & - & - & - & - & - & - \\
\hline Roger's Ruins & & & & & & & & & & & & & & & & & \\
\hline RGR1 & 1.20 & 111 & 68.6 & 1.93 & 6.1 & 3.3 & 18 & 30 & - & 7.03 & - & - & - & - & 21.3 & 4.7 & 0.70468 \\
\hline & 1.15 & 107 & 65.2 & 1.79 & 5.3 & 3.1 & 17 & 27 & 0.0050 & 6.36 & - & - & -2.7 & 0.74 & - & 4.1 & - \\
\hline & - & 111 & 73.8 & 2.04 & - & - & - & - & - & - & - & - & - & - & - & - & - \\
\hline $\operatorname{RGR} 2\left(274^{\circ} \mathrm{C}\right)$ & 0.814 & 91.8 & 42.3 & 1.19 & 3.4 & 1.5 & 26 & 16 & - & 4.80 & -3.1 & -12.8 & -1.2 & 0.70 & - & 1.7 & - \\
\hline & 1.12 & 102 & 66.7 & 1.71 & 5.1 & 2.5 & 42 & 22 & - & 6.37 & -3.7 & -13.0 & -2.0 & 0.77 & - & 4.2 & - \\
\hline & 1.13 & 98.9 & 65.5 & 1.88 & - & - & - & - & - & - & - & - & - & - & - & - & - \\
\hline Satanic Mills & & & & & & & & & & & & & & & & & \\
\hline SM1 $\left(295^{\circ} \mathrm{C}\right)$ & 1.14 & 62.6 & 57.9 & 1.77 & 9.5 & 7.4 & 23 & 14 & - & 168 & -3.1 & -9.1 & -0.2 & 0.90 & - & -2.7 & - \\
\hline & 1.17 & 61.7 & 57.2 & 1.80 & 7.0 & 8.1 & 26 & 15 & 0.098 & 181 & - & - & -3.0 & 0.63 & 20.9 & - & - \\
\hline & - & 62.6 & 61.0 & 1.93 & - & - & - & - & - & - & - & - & - & - & - & - & 0.70497 \\
\hline SM2 $\left(241^{\circ} \mathrm{C}\right)$ & 0.768 & 48.6 & 24.8 & 0.844 & 4.5 & 3.3 & 4.3 & 15 & 0.0042 & 79.6 & - & - & -0.27 & 0.55 & 21.4 & -1.3 & - \\
\hline & - & 34.5 & 36.3 & 1.23 & - & - & - & - & - & - & - & - & - & - & - & - & - \\
\hline SM3 $\left(288^{\circ} \mathrm{C}\right)$ & 1.01 & 69.7 & 56.0 & 1.71 & 5.2 & 8.3 & 6.7 & 26 & 0.034 & 216 & -2.4 & -7.4 & -2.2 & 1.2 & 21.5 & -0.48 & - \\
\hline & 0.990 & 70.4 & 56.2 & 1.72 & 5.9 & 8.3 & 7.0 & 28 & 0.030 & 230 & - & - & -1.8 & 0.83 & 21.8 & -0.52 & 0.70512 \\
\hline & - & 71.1 & 57.9 & 1.81 & - & - & - & - & - & - & - & - & - & - & - & - & - \\
\hline Snowcap & & & & & & & & & & & & & & & & & \\
\hline $\mathrm{SC} 1\left(152^{\circ} \mathrm{C}\right)$ & 0.592 & 43.6 & 18.2 & 0.654 & 0.91 & 2.9 & 7.7 & 35 & 0.033 & 112 & -3.1 & -14.4 & -1.1 & 0.36 & 20.1 & -1.8 & - \\
\hline & 0.222 & 82.3 & 6.02 & 0.141 & 0.15 & 0.54 & 6.5 & 6.1 & - & - & - & - & -2.1 & 0.16 & - & - & - \\
\hline & - & 45.6 & 19.0 & 0.683 & - & - & - & - & - & - & - & - & - & - & - & - & - \\
\hline $\mathrm{SC} 2\left(180^{\circ} \mathrm{C}\right)$ & 0.851 & 55.6 & 27.4 & 1.10 & 1.7 & - & 18 & 36 & 0.045 & 102 & -2.9 & -15.2 & -4.2 & 0.63 & 20.6 & - & 0.70635 \\
\hline & 0.823 & 55.9 & 27.2 & 1.09 & 2.4 & 1.0 & 17 & 34 & - & - & - & - & -2.3 & 1.1 & 20.5 & - & - \\
\hline & - & 55.8 & 28.9 & 1.16 & 2.3 & - & - & - & - & - & - & - & - & - & - & - & - \\
\hline Tsukushi & & & & & & & & & & & & & & & & & \\
\hline TK1 $\left(62{ }^{\circ} \mathrm{C}\right)$ & 0.370 & 93.0 & 12.2 & 0.422 & - & - & 0.16 & 7.1 & 0.040 & 5.74 & - & - & -1.2 & 0.40 & 21.0 & - & - \\
\hline & 0.351 & 93.0 & 11.3 & 0.401 & - & - & 0.57 & 6.5 & 0.0012 & 5.13 & - & - & -1.2 & 0.24 & 21.0 & - & - \\
\hline & - & 92.7 & 12.8 & 0.422 & - & - & - & - & - & - & - & - & - & - & - & - & - \\
\hline Fenway & & & & & & & & & & & & & & & & & \\
\hline $\mathrm{F} 1\left(329^{\circ} \mathrm{C}\right)$ & 1.36 & 95.3 & 53.2 & 1.85 & 7.9 & 18.5 & 24 & 29 & 0.033 & 61.3 & -2.7 & -10.2 & -4.3 & 1.2 & 20.8 & -0.73 & - \\
\hline & - & 95.6 & 55.9 & 1.96 & 6.4 & - & - & - & - & - & - & - & - & - & - & - & - \\
\hline & 0.453 & 90.9 & 15.5 & 0.484 & 1.9 & 4.6 & 6.4 & 7.0 & 0.0031 & 17.7 & 0.0 & - & -2.4 & 0.43 & - & -0.71 & - \\
\hline $\mathrm{F} 2\left(343^{\circ} \mathrm{C}\right)$ & 1.83 & 121 & 87.2 & 2.92 & 8.2 & 9.2 & 95 & 13 & 0.054 & 23.6 & -3.5 & -10.6 & -0.9 & 1.4 & - & 1.2 & - \\
\hline & 1.84 & 117 & 82.2 & 2.93 & 6.9 & 9.0 & 93 & 12 & 0.049 & 23.3 & -2.9 & -11.7 & -1.5 & 1.4 & 20.4 & -1.0 & - \\
\hline & - & 118 & 87.7 & 3.18 & - & - & - & - & - & - & - & - & - & - & - & - & - \\
\hline $\mathrm{F} 3^{*}\left(358^{\circ} \mathrm{C}\right)$ & 1.60 & 103 & 73.5 & 2.49 & 6.1 & 15.0 & 233 & 32 & 0.14 & 44.0 & - & - & -1.6 & 1.4 & 20.9 & -1.2 & 0.70428 \\
\hline & 1.42 & 89.7 & 60.0 & 2.17 & 5.8 & 19.3 & 325 & 44 & 0.16 & 58.6 & -2.6 & -8.6 & -0.3 & 1.1 & 20.8 & -0.20 & 0.70447 \\
\hline & - & 92.9 & 65.0 & 2.38 & - & - & - & - & - & - & - & - & - & - & - & - & 0.70482 \\
\hline $\mathrm{F} 4\left(284^{\circ} \mathrm{C}\right)$ & 1.31 & 86.8 & 57.5 & 2.07 & 7.5 & 11.6 & 25 & 39 & 0.036 & 51.8 & -3.1 & -8.8 & -1.2 & 1.1 & 21.7 & -0.17 & - \\
\hline & 1.32 & 85.8 & 57.3 & 2.08 & 8.4 & 11.6 & 26 & 38 & 0.037 & 54.7 & - & - & -4.0 & 1.4 & 21.5 & 5.4 & 0.70461 \\
\hline & - & 83.3 & 55.6 & 2.05 & - & - & - & - & - & - & - & - & - & - & - & - & - \\
\hline $\mathrm{F} 5\left(80^{\circ} \mathrm{C}\right)$ & 0.268 & 104 & 9.33 & 0.218 & 0.66 & 2.5 & 2.8 & 7.7 & - & 14.4 & - & - & - & - & - & - & - \\
\hline & 0.287 & 104 & 9.35 & 0.256 & 1.2 & 2.7 & 2.7 & 11 & - & 15.5 & - & - & -2.5 & 0.39 & 21.1 & -0.28 & - \\
\hline & - & 97.0 & 3.64 & 0.108 & - & - & - & - & - & - & - & - & - & - & - & - & - \\
\hline NE Pt & & & & & & & & & & & & & & & & & \\
\hline $\mathrm{NP} 1\left(35^{\circ} \mathrm{C}\right)$ & 0.166 & 98.6 & 2.49 & 0.051 & 3.4 & - & 0.18 & 1.0 & - & 3.04 & - & - & -0.13 & 0.38 & 20.9 & - & - \\
\hline & 0.176 & 105 & 2.34 & 0.075 & 2.6 & - & 0.21 & 1.7 & - & 2.51 & - & - & -2.4 & 0.31 & 20.8 & - & - \\
\hline & - & 100 & 2.53 & 0.066 & - & - & - & - & - & - & - & - & - & - & - & - & - \\
\hline Bottom SW $\left(3^{\circ} \mathrm{C}\right)$ & 0.426 & 91.0 & $1.3^{\mathrm{d}}$ & $0.0023^{\mathrm{d}}$ & 0.0 & 0.0 & 0.0 & 0.0 & 0.0 & 2.3 & $0.3^{\mathrm{e}}$ & - & $-0.14^{\mathrm{f}}$ & $-0.17^{\mathrm{g}}$ & $20.99^{\mathrm{h}}$ & - & 0.70916 \\
\hline
\end{tabular}

$\mathrm{mM}, \mathrm{mmol} / \mathrm{L}$ fluid; mm, mmol $/ \mathrm{kg}$ fluid; $\mu \mathrm{m}, \mu \mathrm{mol} / \mathrm{kg}$ fluid; $\mu \mathrm{M}, \mu \mathrm{mol} / \mathrm{L}$ fluid. "—”, not determined; $\mathrm{SW}$, seawater.

Vigorous 2-phase venting.

+ Accidental SW entrainment suspected during sampling (based on temperature monitoring).

a Each vent represents an individual orifice from which multiple samples were taken ( $T_{\max }$, max. observed vent temperature).

b Samples named by Jason (J2) dive number and gas-tight (-IGT) or major (-M) sampler number.

- Sarmiento and Gruber (2006).

d Spencer et al. (1970).

e Craig (1970).

${ }^{f}$ Redfield and Friedman (1965).

Craig and Gordon (1965).

${ }^{h}$ Rees et al. (1978). 
source. While conclusive evidence for magma bodies beneath Pual Ridge is currently lacking, a faint and discontinuous seismic reflector was observed at $\sim 2 \mathrm{~km}$ depth in 2002 (Lee, 2003; Binns et al., 2007). Based on the $\mathrm{Cl}$ and $\mathrm{H}_{2} \mathrm{O}$ contents of volcanic glasses from Pual Ridge and solubility constraints, Sun et al. (2007) also suggested that a magma chamber might be located near this depth. In contrast to Vienna Woods, meter-scale fissures are noticeably absent on the surface of Pual Ridge.

Five main areas of hydrothermal activity were previously documented at PACMANUS, including Roman Ruins, Roger's Ruins, Satanic Mills, Snowcap and Tsukushi (Binns et al., 2007). Compositions of fluids collected at PACMANUS between 1995 and 2000 have previously been reported (Gamo et al., 1996a,b; Ishibashi et al., 1996; Douville et al., 1999a,b; Fourre et al., 2006). The five areas are distributed at depths ranging from $1640 \mathrm{~m}$ to $1710 \mathrm{~m}$ (Fig. 2b and 2c). To the north, hydrothermal activity at the Roman Ruins and smaller Roger's Ruins areas in 2006 (Fig. 2b) consisted of focused black or gray smoker fluids venting from multi-spired, sulfide chimney complexes up to $10 \mathrm{~m}$ tall. Areas of hydrothermal activity to the south encircle the Snowcap Dome (Fig. 2c). Similar styles of venting through smaller sulfide structures were evident at Satanic Mills and diffuse fluid also appeared to be flowing from a nearby depression tentatively identified as the drill hole of ODP Leg 193 Site 1191A (Fig. 2c). A $5.3{ }^{\circ} \mathrm{C}$ temperature anomaly (above ambient) was measured $\sim 15 \mathrm{~cm}$ beneath the surface of the drilling mud/bore-hole cuttings, which were covered by a white microbial mat (Tivey et al., 2006). Sulfide structures at Tsukushi were found to be largely inactive in 2006 and only a single low temperature fluid $\left(62^{\circ} \mathrm{C}\right)$ exiting from an oxide mound fissure was sampled. The Snowcap vent area is a broad knoll of mostly diffuse venting with a small area of moderate temperature $\left(\leqslant 180^{\circ} \mathrm{C}\right.$ ) focused venting confined to the western flank (Fig. 2c). In contrast to the Roman/Roger's Ruins, Satanic Mills and Tsukushi areas, where sulfide structures are located atop rugged surficial lava flows, the Snowcap area is heavily sedimented with hydrothermal precipitate/volcaniclastic debris and lava outcrops are rare. Several outcrops of heavily bleached rocks cemented with native sulfur were observed near active vents in 2006, presumably reflecting previous advanced argillic alteration by acid-sulfate type fluids (Brimhall and Ghiorso, 1983; Gena et al., 2001; Binns et al., 2007). However, no 'white smoker' activity similar to that observed at the DESMOS caldera site (Gamo et al., 1997, 2006) was evident anywhere on Pual Ridge. A new site, Fenway, was discovered $200 \mathrm{~m}$ south of Satanic Mills at $1710 \mathrm{~m}$ depth during this expedition (Fig. 2c). The core area of the Fenway site is a $40 \mathrm{~m}$ diameter two-tiered mound composed of chimney debris, massive anhydrite-sulfide breccia and coarse anhydrite sand. At its summit (1710 m depth), a large black smoker chimney complex was found to be vigorously venting the highest temperature fluids $\left(358^{\circ} \mathrm{C}\right)$ observed at the PACMANUS field to date. Several areas of diffuse venting, including some emanating from anhydrite sand/talus, and occasional gray/black smoker fluids were observed on the flanks of the mound.
Another discrete area of hydrothermal activity was also discovered $\sim 8 \mathrm{~km}$ northeast of PACMANUS on Pual Ridge during this expedition and named Northeast (NE) Pual (Fig. 1b). Fluids venting at NE Pual were predominantly low temperature/diffuse in nature in 2006 and only a single fluid with a maximum temperature of $35^{\circ} \mathrm{C}$ was sampled. The presence of extensive biological activity (snails, shrimp, mussel beds and microbial mats), numerous inactive sulfide chimneys and lack of higher temperature venting suggests hydrothermal activity in this area is waning.

\section{METHODS}

\subsection{Sample collection}

All hydrothermal fluid samples were collected during the July-August 2006 MGLN06MV expedition to the Manus Basin aboard the R/V Melville. Fluids were collected using $150 \mathrm{~mL}$ titanium isobaric gas-tight (IGT) fluid samplers (Seewald et al., 2002) and $755 \mathrm{~mL}$ titanium syringe-style 'major' samplers (Von Damm et al., 1985) deployed from the ROV Jason II. Two to three fluid samples were taken per discrete vent at all sites visited (typically two IGT samplers and one 'major' sampler) resulting in a total of 57 samples from 21 discrete vents at Vienna Woods and Pual Ridge (Table 1). In most cases, fluids were sampled immediately after removing sulfide chimney structures. The temperatures of fluids collected with IGT samplers were monitored in real-time during collection using thermocouple temperature probes mounted adjacent to sampler snorkel tips. Only maximum temperatures for a given vent fluid are reported (uncertainty $\pm 2{ }^{\circ} \mathrm{C}$ ) and temperatures were not measured in real time during deployment of the 'major' samplers.

After recovery of the ROV, fluid samples were processed on board the ship as soon as possible (typically within $12 \mathrm{~h}$ ). Fluids from IGT samplers were used for the analysis of both volatile $\left(\mathrm{H}_{2}, \mathrm{CH}_{4}, \mathrm{CO}, \mathrm{CO}_{2}, \mathrm{H}_{2} \mathrm{~S}\right)$ and dissolved inorganic constituents, whereas only the latter were analyzed from the 'major' samplers as they are not gas-tight. Fluid aliquots for major element $(\mathrm{Na}, \mathrm{Cl}$, $\left.\mathrm{Ca}, \mathrm{K}, \mathrm{SiO}_{2}, \mathrm{SO}_{4}, \mathrm{Br}, \mathrm{F}\right)$ and trace metal (Fe, Mn, Li, $\mathrm{B}, \mathrm{Sr}, \mathrm{Rb}, \mathrm{Cs}$ ) determination were transferred to acidcleaned high-density polyethylene (HDPE) Nalgene ${ }^{\mathrm{TM}}$ bottles and analyzed onshore. Aliquots for trace metal analysis were acidified with analytical-grade Optima ${ }^{\circledR} \mathrm{HCl}$ prior to storage. Subsamples of acidified aliquots were diluted 100 -fold onboard ship and stored for shore-based measurement of aqueous silica $\left(\mathrm{SiO}_{2}\right)$. Prior to storage, separate fluid aliquots were sparged with $\mathrm{N}_{2}$ to remove all dissolved $\mathrm{H}_{2} \mathrm{~S}$ for analysis of $\mathrm{SO}_{4}$ concentration and $\mathrm{S}$ isotopic composition $\left(\delta^{34} \mathrm{~S}_{\mathrm{SO}_{4}}\right)$. Fluid aliquots for the onshore determination of dissolved inorganic carbon $\left(\Sigma \mathrm{CO}_{2}\right.$, hereafter abbreviated as $\left.\mathrm{CO}_{2}\right)$ and the stable carbon isotope composition of $\mathrm{CO}_{2}\left(\delta^{13} \mathrm{C}_{\mathrm{CO}_{2}}\right)$ and $\mathrm{CH}_{4}\left(\delta^{13} \mathrm{C}_{\mathrm{CH}_{4}}\right)$ were stored in evacuated $25 \mathrm{~mL}$ serum vials sealed with butyl rubber stoppers. Fluid aliquots were also flame-sealed in glass ampoules for stable hydrogen $\left(\delta \mathrm{D}_{\mathrm{H}_{2} \mathrm{O}}\right)$ and oxygen $\left(\delta^{18} \mathrm{O}_{\mathrm{H}_{2} \mathrm{O}}\right)$ isotope analysis. 


\subsection{Analytical methods}

Aqueous $\mathrm{H}_{2}, \mathrm{CH}_{4}$ and $\mathrm{CO}$ concentrations were determined onboard ship by molecular sieve gas chromatography (GC) with thermal conductivity detection (for $\mathrm{H}_{2}$ and $\mathrm{CH}_{4}$ ) and helium ionization detection (for $\mathrm{CO}$ ) following a syringe headspace extraction. $\mathrm{pH}$ (at $25^{\circ} \mathrm{C}, 1 \mathrm{~atm}$ ) was measured potentiometrically onboard ship using a $\mathrm{Ag} /$ $\mathrm{AgCl}$ combination reference electrode. Concentrations of total dissolved sulfide $\left(\Sigma \mathrm{H}_{2} \mathrm{~S}\right.$, hereafter abbreviated as $\mathrm{H}_{2} \mathrm{~S}$ ) were determined gravimetrically at WHOI following shipboard precipitation as $\mathrm{Ag}_{2} \mathrm{~S}$ in a $5 \mathrm{wt} \% \mathrm{AgNO}_{3}$ solution. $\mathrm{Ag}_{2} \mathrm{~S}$ precipitates were stored in $\mathrm{AgNO}_{3}$ solution for $\delta^{34} \mathrm{~S}$ analysis of $\mathrm{H}_{2} \mathrm{~S}\left(\delta^{34} \mathrm{~S}_{\mathrm{H}_{2} \mathrm{~S}}\right) . \mathrm{CO}_{2}$ concentrations were determined onshore after acidification of fluids with $25 \mathrm{wt} \%$ phosphoric acid by injecting aliquots of headspace gas directly onto a GC with a Porapak ${ }^{\mathrm{TM}} \mathrm{Q}$ packed column and a thermal conductivity detector. These data were corrected to account for $\mathrm{CO}_{2}$ partitioning between the headspace and fluid phases within each individual serum vial. Dissolved gas concentrations are expressed in concentration units of either mmol/L fluid $\left(\mathrm{H}_{2} \mathrm{~S}, \mathrm{H}_{2}, \mathrm{CO}\right.$ and $\left.\mathrm{CH}_{4}\right)$ for gases analyzed at sea or mmol/kg fluid $\left(\mathrm{CO}_{2}\right)$ for species analyzed in shore-based laboratories. The analytical uncertainty (2s) is $\pm 10 \%$ for $\mathrm{H}_{2}, \mathrm{CH}_{4}, \mathrm{CO}$ and $\mathrm{H}_{2} \mathrm{~S}$ concentrations, $\pm 5 \%$ for $\mathrm{CO}_{2}$ concentrations and \pm 0.02 for $\mathrm{pH}$ $\left(25^{\circ} \mathrm{C}\right)$ measurements.

The concentrations of the major elements were determined by ion chromatography. Concentrations of $\mathrm{Sr}, \mathrm{Li}$, $\mathrm{Rb}, \mathrm{Cs}, \mathrm{Fe}, \mathrm{Mn}$ and $\mathrm{Al}$ were determined by inductively coupled plasma-mass spectrometry (ICP-MS) at WHOI (see Craddock (2008) for details). To correct for the effects of sulfide precipitate formation within the fluid samplers, reported Fe data represent the 'total' concentrations obtained by summation of the dissolved and precipitated $\mathrm{Fe}$ fractions from a given sampler (Trefry et al., 1994; Craddock, 2008). Dissolved $\mathrm{SiO}_{2}$ and $\mathrm{B}$ concentrations were determined by inductively coupled plasma-optical emission spectrometry (ICP-OES) at the University of South Florida. The analytical uncertainty (2s) is $\pm 5 \%$ for $\mathrm{Na}, \mathrm{Cl}, \mathrm{Ca}, \mathrm{K}$, $\mathrm{SO}_{4}, \mathrm{Br}$, and $\mathrm{F}$ concentrations, $\pm 10 \%$ for $\mathrm{Sr}, \mathrm{Li}, \mathrm{Rb}, \mathrm{Cs}$, $\mathrm{Fe}, \mathrm{Mn}$ and $\mathrm{Al}$ concentrations and $\pm 2 \%$ for $\mathrm{SiO}_{2}$ and $\mathrm{B}$ concentrations.

$\delta^{13} \mathrm{C}_{\mathrm{CO}_{2}}$ and $\delta^{13} \mathrm{C}_{\mathrm{CH}_{4}}$ values were determined at WHOI on a subset of samples by isotope ratio monitoring-gas chromatography mass spectrometry (irm-GC/MS) using a Finnigan Delta ${ }^{\text {Plus }} \mathrm{XL}$ mass spectrometer interfaced to an Agilent 6890 gas chromatograph through a GCCIII interface (combustion furnace was held at $950{ }^{\circ} \mathrm{C}$ for carbon isotope analysis). The pooled standard deviation (1s) is $0.3 \%$ for both $\delta^{13} \mathrm{C}_{\mathrm{CO}_{2}}$ and $\delta^{13} \mathrm{C}_{\mathrm{CH}_{4}}$ datasets. $\delta^{34} \mathrm{~S}_{\mathrm{H}_{2} \mathrm{~S}}$ measurements were conducted on $\mathrm{Ag}_{2} \mathrm{~S}$ precipitates with an automated elemental analyzer interfaced with an isotope ratio mass spectrometer at the USGS, Denver. $\mathrm{SO}_{4}$ in selected fluid samples was precipitated as $\mathrm{BaSO}_{4}$ prior to $\delta^{34} \mathrm{~S}_{\mathrm{SO}_{4}}$ determination by the same method. Analytical uncertainty for all $\delta^{34} \mathrm{~S}$ data is $\pm 0.3 \%$ o $(2 \mathrm{~s})$. Oxygen isotope compositions of vent fluid $\mathrm{H}_{2} \mathrm{O}\left(\delta^{18} \mathrm{O}_{\mathrm{H}_{2} \mathrm{O}}\right)$ were analyzed using an automated $\mathrm{CO}_{2}$ equilibration device on a VG Optima mass spectrometer at the USGS, Denver. Hydrogen isotope compositions $\left(\delta \mathrm{D}_{\mathrm{H}_{2} \mathrm{O}}\right)$ of vent fluid $\mathrm{H}_{2} \mathrm{O}$ were analyzed as $\mathrm{H}_{2}$ on a Finnigan MAT 252 mass spectrometer at the USGS, Denver. $\mathrm{H}_{2}$ was prepared by the $\mathrm{Zn}$ reduction technique (Kendall and Coplen, 1985) following salt removal by vacuum distillation. Analytical uncertainties (1s) for $\delta^{18} \mathrm{O}_{\mathrm{H}_{2} \mathrm{O}}$ and $\delta \mathrm{D}_{\mathrm{H}_{2} \mathrm{O}}$ values are estimated to be $0.1 \%$ and $1.5 \%$, respectively.

Strontium isotope analyses $\left({ }^{87} \mathrm{Sr} /{ }^{86} \mathrm{Sr}\right)$ of fluids were conducted on a Finnigan MAT 261 thermal ionization mass spectrometer at the Freie Universität Berlin by static multi-collection (for further details, see Eickmann et al. (2009)). External reproducibility of ${ }^{87} \mathrm{Sr} /{ }^{86} \mathrm{Sr}$ data is estimated to be on the order of 0.00007 (2s) based on three individually processed aliquots of IAPSO reference seawater $\left({ }^{87} \mathrm{Sr} /{ }^{86} \mathrm{Sr}\right.$ of $\left.0.709134 \pm 0.000066,2 \mathrm{~s}, n=3\right)$. Both this and the value for ambient bottom seawater in the Manus Basin (Table 1) are within error of the published value for seawater (0.70916, Banner, 2004). With the exception of ${ }^{87} \mathrm{Sr} /{ }^{86} \mathrm{Sr}$, all stable isotope data are reported using standard delta notation. For the isotope of interest, $A, \delta A$ is defined by the following expression:

$\delta A(\%)=\left[\frac{R_{S}-R_{S T D}}{R_{S T D}}\right] \times 1000$

Where $R_{S}$ and $R_{S T D}$ are the isotope ratios of the sample and standard, respectively. $\delta^{13} \mathrm{C}_{\mathrm{CO}_{2}}$ values are expressed relative to the $\mathrm{V}$-PDB scale, while all $\delta^{34} \mathrm{~S}$ data are and V-CDT scales. $\delta^{18} \mathrm{O}_{\mathrm{H}_{2} \mathrm{O}}$ and $\delta \mathrm{D}_{\mathrm{H}_{2} \mathrm{O}}$ values are both expressed relative to $\mathrm{V}-\mathrm{SMOW}$, with $\delta^{18} \mathrm{O}_{\mathrm{H}_{2} \mathrm{O}}$ values representing isotope activity ratios and $\delta \mathrm{D}_{\mathrm{H}_{2} \mathrm{O}}$ values representing concentration ratios as per convention (Shanks et al., 1995; Shanks, 2001).

\subsection{Calculation of endmember compositions}

The fluid samplers used in this study have finite snorkel and valve dead volumes that were filled with bottom seawater prior to deployment. Vent fluids can mix with seawater prior to venting at the seafloor either within vent structures or elsewhere in the subseafloor plumbing system and/or accidentally during the sampling process. Hence, the composition of collected fluids invariably reflects two-component mixing of seawater and a hydrothermal fluid 'endmember'. The endmember is conventionally assumed to be devoid of $\mathrm{Mg}$ for all practical purposes, reflecting the composition of pure hydrothermal fluids prior to any seawater admixing. This assumption is based on experimental evidence for near-quantitative removal of $\mathrm{Mg}$ from seawater during hydrothermal interactions with basalt, andesite, and rhyolite at reaction zone conditions typical of seafloor hydrothermal systems (Bischoff and Dickson, 1975; Mottl and Holland, 1978; Seyfried and Bischoff, 1981; Hajash and Chandler, 1982; Shiraki et al., 1987; Ogawa et al., 2005). In most cases, absolute Mg concentrations in typical MOR vent fluids considered to be endmembers are not resolvable from inherent sampler dead volume contributions.

It has been suggested that the highly acidic nature of many back-arc basin fluids may reverse $\mathrm{Mg}$ removal reactions, thereby invalidating the assumption that a near-zero 
Table 2

Summary of vent fluid compositions extrapolated to zero Mg concentration from the Vienna Woods, PACMANUS and NE Pual vent fields, Manus Basin.

\begin{tabular}{|c|c|c|c|c|c|c|c|c|c|c|c|c|c|c|}
\hline $\begin{array}{l}\text { Vent Field } \\
\text { Area: VENT }\end{array}$ & $\begin{array}{l}T_{\max } \\
\left({ }^{\circ} \mathrm{C}\right)\end{array}$ & $\begin{array}{l}\mathrm{Mg}_{\min } \\
(\mathrm{mm})\end{array}$ & $\begin{array}{l}\mathrm{pH}_{\min } \\
\left(25^{\circ} \mathrm{C}\right)\end{array}$ & $\begin{array}{l}\mathrm{Na} \\
(\mathrm{mm})\end{array}$ & $\begin{array}{l}\mathrm{Cl} \\
(\mathrm{mm})\end{array}$ & $\begin{array}{l}\mathrm{Ca} \\
(\mathrm{mm})\end{array}$ & $\begin{array}{l}\mathrm{K} \\
(\mathrm{mm})\end{array}$ & $\begin{array}{l}\mathrm{SiO}_{2} \\
(\mathrm{~mm})\end{array}$ & $\begin{array}{l}\mathrm{Br} \\
(\mathrm{mm})\end{array}$ & $\begin{array}{l}\mathrm{F} \\
(\mathrm{mm})\end{array}$ & $\begin{array}{l}\mathrm{Fe} \\
(\mathrm{mm})\end{array}$ & $\begin{array}{l}\mathrm{Mn} \\
(\mathrm{mm})\end{array}$ & $\begin{array}{l}\mathrm{Li} \\
(\mathrm{mm})\end{array}$ & $\begin{array}{l}\mathrm{B} \\
(\mathrm{mm})\end{array}$ \\
\hline \multicolumn{15}{|l|}{ Vienna Woods } \\
\hline VW1 & 282 & 1.44 & 4.4 & 513 & 691 & 80.1 & 21.2 & 15.3 & 1.06 & 0.019 & 0.15 & 0.351 & 1.08 & 0.236 \\
\hline VW2 & 273 & 1.02 & 4.2 & 509 & 690 & 80.9 & 21.2 & 15.0 & 1.06 & 0.021 & 0.17 & 0.365 & 1.16 & 0.246 \\
\hline VW3 & 285 & 1.11 & 4.7 & 504 & 672 & 70.7 & 20.1 & 14.6 & 1.02 & 0.019 & 0.12 & 0.211 & 1.07 & 0.186 \\
\hline \multicolumn{15}{|l|}{ PACMANUS } \\
\hline \multicolumn{15}{|l|}{ Roman Ruins } \\
\hline RMR1 & 314 & 7.26 & 2.3 & 477 & 632 & 19.8 & 81.7 & 15.7 & 0.947 & 0.135 & 6.52 & 3.97 & 1.13 & 2.07 \\
\hline RMR2 & 272 & 15.9 & 2.3 & 417 & 551 & 10.5 & 68.5 & 23.9 & 0.802 & 0.113 & 1.42 & 3.31 & 0.895 & 1.74 \\
\hline RMR3 & 278 & 6.39 & 2.5 & 541 & 731 & 25.5 & 96.8 & 20.5 & 1.13 & 0.167 & 7.75 & 4.79 & 1.32 & 2.17 \\
\hline RMR4 & 341 & 3.63 & 2.6 & 497 & 658 & 23.1 & 82.1 & 19.0 & 1.04 & 0.126 & 6.86 & 3.02 & 1.09 & 1.70 \\
\hline \multicolumn{15}{|l|}{ Roger's Ruins } \\
\hline RGR1 & 320 & 4.24 & 2.7 & 488 & 648 & 27.1 & 81.1 & 18.8 & 1.00 & 0.158 & 4.64 & 2.76 & 0.888 & 1.28 \\
\hline RGR2 & 274 & 8.61 & 2.6 & 485 & 650 & 24.7 & 80.4 & 19.0 & 1.00 & 0.148 & 3.88 & 2.58 & 0.901 & 1.23 \\
\hline \multicolumn{15}{|l|}{ Satanic Mills } \\
\hline SM1 & 295 & 8.16 & 2.6 & 397 & 517 & 12.8 & 69.6 & 14.5 & 0.799 & 0.187 & 3.42 & 2.63 & 0.769 & 1.31 \\
\hline SM2 & 241 & 16.9 & 2.4 & 328 & 414 & 3.59 & 52.4 & 19.0 & 0.630 & 0.386 & 1.58 & 2.41 & 0.627 & 1.12 \\
\hline SM3 & 288 & 9.72 & 2.5 & 387 & 503 & 13.7 & 68.0 & 15.1 & 0.766 & 0.234 & 1.22 & 2.31 & 0.726 & 1.13 \\
\hline \multicolumn{15}{|l|}{ Snowcap } \\
\hline $\mathrm{SCl}$ & 152 & 30.8 & 4.6 & 343 & 441 & 0.508 & 46.4 & 16.4 & 0.672 & 0.220 & 0.076 & 2.55 & 0.714 & 0.779 \\
\hline $\mathrm{SC} 2$ & 180 & 24.2 & 3.4 & 408 & 526 & 3.38 & 55.9 & 17.5 & 0.831 & 0.259 & 0.27 & 3.02 & 0.893 & 1.20 \\
\hline \multicolumn{15}{|l|}{ Tsukushi } \\
\hline TK1 & 62 & 44.4 & 5.7 & 505 & 749 & 23.7 & 81.3 & 22.8 & 1.28 & 0.154 & 0.81 & 3.92 & 1.33 & -0.021 \\
\hline \multicolumn{15}{|l|}{ Fenway } \\
\hline $\mathrm{F} 1$ & 329 & 5.84 & 2.6 & 326 & 454 & 14.8 & 59.3 & 14.3 & 0.705 & 0.313 & 8.42 & 2.74 & 0.724 & 1.42 \\
\hline $\mathrm{F} 2$ & 343 & 4.66 & 2.7 & 486 & 699 & 26.9 & 94.3 & 15.2 & 1.10 & 0.181 & 14.6 & 4.75 & 1.15 & 1.99 \\
\hline F3 & 358 & 4.52 & 2.7 & 397 & 562 & 22.3 & 76.1 & 12.2 & 0.882 & 0.172 & 11.8 & 3.80 & 0.917 & 1.61 \\
\hline $\mathrm{F} 4$ & 284 & 8.69 & 2.5 & 377 & 523 & 19.1 & 70.5 & 13.3 & 0.829 & 0.177 & 8.26 & 3.62 & 0.839 & 1.50 \\
\hline F5 & 80 & 44.0 & 4.9 & 240 & 388 & 31.8 & 42.1 & 11.3 & 0.738 & 0.181 & 4.57 & 2.31 & 0.599 & -0.55 \\
\hline \multicolumn{15}{|l|}{ NE Pual } \\
\hline NP1 & 35 & 49.9 & 6.9 & 205 & 410 & 84.8 & 29.6 & 22.8 & 0.586 & 0.220 & 2.62 & 4.23 & 0.475 & -5.6 \\
\hline Bottom SW & 3 & 52.4 & 7.9 & 471 & 540 & 10.5 & 9.9 & $0.13^{\mathrm{a}}$ & 0.808 & 0.064 & 0.0 & 0.0 & 0.028 & 0.426 \\
\hline
\end{tabular}

Mg composition exists in the subsurface (Gamo et al., 1997; Douville et al., 1999a; Butterfield et al., 2003). As presented below, however, hotter fluids within each Pual Ridge vent area invariably have lower $\mathrm{Mg}$ concentrations, and the hottest fluids sampled overall have $<10 \%$ of the seawater $\mathrm{Mg}$ value (Table 1). These trends are consistent with twocomponent mixing between seawater and a hydrothermal endmember depleted in $\mathrm{Mg}$. For the purposes of our interpretations, we therefore assume that $\mathrm{Mg}$ in our samples is predominantly derived from either subsurface or sampling-related seawater entrainment and our endmember compositions are arbitrarily assumed to contain zero $\mathrm{Mg}$. The possibility that some small fraction of the observed $\mathrm{Mg}$ concentrations may not be seawater-derived is discussed later, but our interpretations would not change significantly if all our endmember compositions were calculated at the lowest $\mathrm{Mg}$ concentration in each vent fluid (as proposed by Douville et al. (1999a)). While such an approach more accurately reflects compositions venting at the seafloor, it is equally arbitrary, only minimizes the effect of sampling-related entrainment and is therefore equivocal as to the origin of high $\mathrm{Mg}$ concentrations. Because subsurface seawater entrainment invariably results in dilution or concentration effects, use of endmember compositions calculated at differing $\mathrm{Mg}$ concentrations would complicate interpretation of species that behave conservatively during this process. By consistently using zero $\mathrm{Mg}$ compositions, the abundances of conservative species prior to seawater admixing are more accurately represented. In addition, trends in anomalous calculated endmember values with $\mathrm{Mg}$ concentrations are useful in indicating where and how subsurface seawater entrainment has modified the original endmember compositions of non-conservative species through associated reactions, even if calculated endmembers for such species may not represent real compositions.

All endmember values referred to hereafter are calculated by extrapolating measured concentrations of individual species in multiple fluid samples from a given vent orifice to zero $\mathrm{Mg}$ concentration using a linear least squares regression weighted to pass through ambient bottom seawater concentrations (Tables 1 and 2, Von Damm et al., 1985). Endmember $\delta^{18} \mathrm{O}_{\mathrm{H}_{2} \mathrm{O}}$ and $\delta \mathrm{D}_{\mathrm{H}_{2} \mathrm{O}}$ values are calculated by extrapolation to zero $\mathrm{Mg}$ as per species concentrations. Measured $\delta^{13} \mathrm{C}_{\mathrm{CO}_{2}}$ values for each sample are corrected to endmember values assuming $2.3 \mathrm{mmol} / \mathrm{kg}$ $\mathrm{CO}_{2}$ in entrained seawater (see Cruse and Seewald, 2006). In cases where multiple samples from a given vent orifice were analyzed, endmember $\delta^{13} \mathrm{C}_{\mathrm{CO}_{2}}, \delta^{13} \mathrm{C}_{\mathrm{CH}_{4}}$ and $\delta^{34} \mathrm{~S}_{\mathrm{H}_{2} \mathrm{~S}}$ values are averaged. Endmember ${ }^{87} \mathrm{Sr} /{ }^{86} \mathrm{Sr}$ ratios are calculated by extrapolating measured molar $\mathrm{Mg} / \mathrm{Sr}$ ratios to zero according to the method of Albarède et al. (1981). Where the effects of subsurface seawater entrainment obscure com- 
Table 2 (continued)

\begin{tabular}{|c|c|c|c|c|c|c|c|c|c|c|c|c|c|c|}
\hline $\begin{array}{l}\mathrm{Sr} \\
(\mu \mathrm{m})\end{array}$ & $\begin{array}{l}\mathrm{Rb} \\
(\mu \mathrm{m})\end{array}$ & $\begin{array}{l}\mathrm{Cs} \\
(\mu \mathrm{m})\end{array}$ & $\begin{array}{l}\mathrm{Al} \\
(\mu \mathrm{m})\end{array}$ & $\begin{array}{l}\Sigma \mathrm{H}_{2} \mathrm{~S} \\
(\mathrm{mM})\end{array}$ & $\begin{array}{l}\mathrm{H}_{2} \\
(\mu \mathrm{M})\end{array}$ & $\begin{array}{l}\mathrm{CH}_{4} \\
(\mu \mathrm{M})\end{array}$ & $\begin{array}{l}\mathrm{CO} \\
(\mu \mathrm{M})\end{array}$ & $\begin{array}{l}\Sigma \mathrm{CO}_{2} \\
(\mathrm{~mm})\end{array}$ & $\begin{array}{l}\delta^{13} \mathrm{C}_{\mathrm{CO}_{2}} \\
(\%)\end{array}$ & $\begin{array}{l}\delta^{13} \mathrm{C}_{\mathrm{CH}_{4}} \\
(\% \%)\end{array}$ & $\begin{array}{l}\delta \mathrm{D}_{\mathrm{H}_{2} \mathrm{O}} \\
(\% \circ)\end{array}$ & $\begin{array}{l}\delta^{18} \mathrm{O}_{\mathrm{H}_{2} \mathrm{O}} \\
(\% \%)\end{array}$ & $\begin{array}{l}\delta^{34} \mathrm{~S}_{\mathrm{H}_{2} \mathrm{~S}} \\
(\% \mathrm{oo})\end{array}$ & ${ }^{87} \mathrm{Sr} /{ }^{86} \mathrm{Sr}$ \\
\hline 242 & 18.3 & 0.291 & 6.6 & 1.4 & 43 & 66 & - & 4.38 & -5.4 & -20.7 & 2.4 & 0.56 & - & 0.70435 \\
\hline 247 & 18.4 & 0.286 & 7.5 & 1.6 & 56 & 71 & - & 4.43 & -5.2 & -20.7 & 2.6 & & - & - \\
\hline 225 & 17.2 & 0.261 & 7.0 & 1.5 & 44 & 64 & - & 4.48 & -5.7 & -20.8 & 1.3 & 0.49 & - & - \\
\hline 76.3 & 75.4 & 2.69 & 9.3 & 7.5 & 76 & 31 & 0.052 & 17.5 & -3.4 & -13.4 & -0.42 & 1.2 & 1.4 & - \\
\hline 48.9 & 61.2 & 2.24 & 7.6 & 4.0 & 41 & 51 & 0.033 & 26.5 & -3.1 & -13.3 & -3.2 & 1.6 & 2.8 & - \\
\hline 83.7 & 90.0 & 3.17 & 14.6 & 4.4 & 127 & 14 & 0.041 & 10.1 & - & - & -4.5 & 1.6 & 2.1 & - \\
\hline 86.9 & 79.2 & 2.44 & 6.3 & 6.8 & 57 & 23 & - & 10.1 & -4.1 & - & -2.7 & 1.1 & 0.0 & 0.70425 \\
\hline 112 & 77.4 & 2.15 & 6.5 & 3.6 & 20 & 32 & 0.006 & 7.31 & - & - & -3.1 & 0.90 & 4.4 & 0.70429 \\
\hline 101 & 78.0 & 2.14 & 6.1 & 2.8 & 49 & 27 & - & 7.04 & -3.9 & -12.9 & -2.3 & 1.1 & 2.9 & - \\
\hline 56.4 & 70.6 & 2.21 & 10.1 & 9.4 & 30 & 17 & 0.12 & 212 & -3.1 & -9.1 & -2.0 & 0.97 & -2.7 & 0.70374 \\
\hline 6.68 & 51.6 & 1.78 & 9.2 & 6.8 & 8.7 & 31 & 0.009 & 160 & - & - & -0.40 & 1.3 & -1.3 & - \\
\hline 65.7 & 69.4 & 2.15 & 6.8 & 10.2 & 8.4 & 33 & 0.039 & 274 & -2.3 & -7.4 & -2.4 & 1.3 & -0.50 & 0.70383 \\
\hline-23.4 & 44.0 & 1.65 & 2.2 & 7.0 & 20 & 85 & 0.079 & 268 & -3.3 & -14.4 & -2.8 & 1.2 & -1.8 & - \\
\hline 24.9 & 51.1 & 2.10 & 3.9 & 1.9 & 32 & 66 & 0.084 & 187 & -3.0 & -15.2 & -6.0 & 1.8 & - & 0.69768 \\
\hline 104 & 75.9 & 2.86 & $\mathrm{n} / \mathrm{d}$ & - & 2.4 & 47 & 0.15 & 24.1 & - & - & & & - & - \\
\hline 95.8 & 61.3 & 2.14 & 8.1 & 20.8 & 27 & 32 & 0.036 & 68.7 & -2.7 & -10.2 & -5.2 & 1.4 & -0.72 & - \\
\hline 122 & 94.5 & 3.32 & 8.4 & 10.1 & 104 & 14 & 0.057 & 25.7 & -3.3 & -11.1 & -1.4 & 1.6 & 0.10 & - \\
\hline 95.9 & 74.6 & 2.65 & 6.5 & 18.8 & 306 & 42 & 0.17 & 56.1 & -3.0 & -8.6 & -1.0 & 1.4 & -0.72 & 0.70394 \\
\hline 84.2 & 68.7 & 2.51 & 9.6 & 14.0 & 31 & 46 & 0.044 & 63.6 & -3.0 & -8.8 & -3.1 & 1.5 & 2.6 & 0.70364 \\
\hline 176 & 53.6 & 1.57 & 6.3 & 17.2 & 18 & 62 & - & 86.4 & - & - & - & - & -0.28 & - \\
\hline 352 & 28.8 & 1.55 & 69 & - & 4.7 & 35 & - & 12.0 & - & - & - & - & - & - \\
\hline $91.0 \mathrm{o}$ & $1.3^{\mathrm{b}}$ & 0.0023 & 0.0 & 0.0 & 0.0 & 0.0 & 0.0 & 2.3 & $0.3^{\mathrm{c}}$ & - & $-0.14^{\mathrm{d}}$ & $-0.17^{\mathrm{e}}$ & - & 0.70916 \\
\hline
\end{tabular}

$\mathrm{mM}, \mathrm{mmol} / \mathrm{L}$ fluid; $\mathrm{mm}, \mathrm{mmol} / \mathrm{kg}$ fluid; $\mu \mathrm{m}, \mu \mathrm{mol} / \mathrm{kg}$ fluid; $\mu \mathrm{M}, \mu \mathrm{mol} / \mathrm{L}$ fluid; $T_{\max }$, max. observed temperature at vent; SW, seawater; $\mathrm{Mg}_{\min }$, lowest $\mathrm{Mg}$ concentration for vent fluid; $\mathrm{pH}_{\text {min }}$, lowest $\left(25^{\circ} \mathrm{C}\right) \mathrm{pH}$ for vent fluid; “- “, not determined.

a Sarmiento and Gruber (2006).

b Spencer et al. (1970).

c Craig (1970).

d Redfield and Friedman (1965).

e Craig and Gordon (1965).

parisons of true endmember concentrations, we only discuss zero $\mathrm{Mg}$ endmembers calculated from fluids which have the lowest $\mathrm{Mg}$ concentrations in a given vent field on the assumption that these fluids most closely resemble true endmembers prior to entrainment-related modification. However, where it assists in deconvolving the effects on endmember compositions of processes solely related to subsurface seawater entrainment, species concentrations calculated at the lowest $\mathrm{Mg}$ concentration measured for a fluid (referred to as 'minimum $\mathrm{Mg}$ ') are sometimes used in addition to the zero $\mathrm{Mg}$ endmembers.

\section{RESULTS}

\subsection{Temperature}

Focused high-temperature fluids with near zero measured $\mathrm{Mg}$ concentrations were sampled from each of the three main structures at Vienna Woods (Fig. 2a and Table 1). The three fluids exhibited a narrow range of temperatures $\left(273-285^{\circ} \mathrm{C}\right.$ ) and endmember compositions (Tables 1 and 2) despite being located 100-150 m apart, suggesting that the Vienna Woods field is fed by a common source fluid. Though $\mathrm{pH}\left(25^{\circ} \mathrm{C}\right)$ and endmember fluid compositions have remained relatively constant since previous expeditions, slightly hotter maximum temperatures (302 and $292^{\circ} \mathrm{C}$ ) were measured in 1995 and 2000, respectively (Lisitsyn et al., 1993; Auzende et al., 1996; Gamo et al., 1997; Douville et al., 1999a; Fourre et al., 2006). In general, almost all aspects of the chemistry of fluids venting at Vienna Woods are similar to observations from basalt-hosted hydrothermal systems in MOR settings (Von Damm, 1995; German and Von Damm, 2003).

At Pual Ridge, focused fluids were sampled from 17 discrete orifices at PACMANUS (Fig. 2b and 2c) and one diffusely venting structure at NE Pual (Fig. 1b). Vent fluids sampled at Pual Ridge in 2006 show a wider range of temperatures than were observed at Vienna Woods (Tables 1 and 2). The hottest fluids were observed at the summit of the Fenway mound, where samples taken at F2 and F3 vents had maximum temperatures of 343 and $358^{\circ} \mathrm{C}$, respectively (Table 1 ). Fluids at F3 vent exhibited a 'flashing' phenomenon whereby exiting fluid was highly reflective under ROV lighting, but changed to smoke-like precipitate 
a few $\mathrm{cm}$ above the vent orifice. The phenomenon can be attributed to vigorous 2-phase fluid venting (Massoth et al., 1989; Hannington et al., 2001; Stoffers et al., 2006). At a depth of $1710 \mathrm{~m}(\sim 171$ bar pressure $)$ the fluid at F3 lies on the 2-phase boundary for a $3.2 \mathrm{wt} \% \mathrm{NaCl}$ solution (Bischoff and Rosenbauer, 1985), consistent with subcritical boiling (Fig. 3). Measured temperatures at other vent areas on Pual Ridge were considerably lower than this, ranging from 35 to $343{ }^{\circ} \mathrm{C}$.

\section{2. $\mathrm{Mg}$ and $\mathrm{SO}_{4}$}

For most IGT samples taken at Vienna Woods, Mg concentrations are less than $1.6 \mathrm{mmol} / \mathrm{kg}$ (the estimated maximum contribution of 'dead volume' seawater $\mathrm{Mg}$ for the sampler type $(<4 \mathrm{~mL}$, Seewald et al., 2002) $)$ and are therefore consistent with venting of near zero $\mathrm{Mg}$ fluids at the seafloor. Measured $\mathrm{Mg}$ concentrations from all IGT samples collected at Pual Ridge (3.63-50.6 mmol $/ \mathrm{kg})$, however, are greater than the dead volume contribution (Table 1), suggesting entrainment of seawater. Many fluids sampled with both IGT and 'major' samplers have three near-identical measured $\mathrm{Mg}$ concentrations for different sampler types (RMR1, SM3, SC2, TK1, F2 and NP1 in Table 1). Sample sets from other vent fluids have two similar Mg values with a third (often suspected of accidental seawater entrainment during sampling) having much higher $\mathrm{Mg}$ (RMR2, RGR2, SC1, F1, F3, F4 and F5). It is unlikely that such consistently high $\mathrm{Mg}$ concentrations in repeat samples of a given vent fluid (with different sampler types) could be the result of accidental entrainment of near-identical amounts of seawater during each sampling event. Therefore, these observations indicate that most, it not all, fluids exiting at the seafloor at Pual Ridge contain high concentrations of $\mathrm{Mg}$ relative to Vienna Woods fluids where $\mathrm{Mg}$ is near zero. Fluid samples taken at PACMANUS in 1995 also contained high $\mathrm{Mg}$ concentrations (Gamo et al., 1996a; Douville et al., 1999a; Fourre et al., 2006) and do not suggest the presence of a near zero $\mathrm{Mg}$ fluid venting at the seafloor at that time either. The hottest fluids in any given vent area at Pual Ridge invariably have the lowest $\mathrm{Mg}$ concentrations and samples containing less than $10 \%$ of seawater $\mathrm{Mg}$ were taken from vents with temperatures greater than $300^{\circ} \mathrm{C}$ (Table 1$)$.

For all Vienna Woods samples, both measured $\mathrm{Mg}$ and $\mathrm{SO}_{4}$ concentrations decrease linearly to near zero (Fig. 4). In contrast, $\mathrm{SO}_{4}$ abundances in Pual Ridge vent fluids deviate from this behavior toward both positive and negative apparent endmember $\mathrm{SO}_{4}$ concentrations. $\delta^{34} \mathrm{~S}_{\mathrm{SO}_{4}}$ values for all Pual Ridge fluids (Table 1) lie within a narrow range $(+20.1 \%$ to $+21.8 \%$ o $)$ indicative of seawater-derived $\mathrm{SO}_{4}$ $\left(+20.99 \%\right.$, Rees et al., 1978). As all $\mathrm{SO}_{4}$ is likely seawater-derived, endmember $\mathrm{SO}_{4}$ concentrations are not explicitly calculated. Combined with high measured $\mathrm{Mg}$ concentrations, the predominance of seawater $\mathrm{SO}_{4}$ suggests that many, if not all, fluids venting as focused flow at the seafloor at Pual Ridge entrained seawater prior to exiting. Low temperature fluids at Fenway $\left(\mathrm{F} 5,80^{\circ} \mathrm{C}\right)$ and NE Pual $\left(\mathrm{NP} 1,35^{\circ} \mathrm{C}\right.$ ) have $\mathrm{SO}_{4}$ concentrations that are similar to or slightly greater than ambient seawater, but $\mathrm{Mg}$ concentra- tions that are lower (Table 1 and Fig. 4). Samples from both fluids therefore display positive deviations from the trends observed at Vienna Woods and Pual Ridge.

\section{3. $\mathrm{pH}$}

Endmember $\mathrm{pH}$ values were not calculated because of the numerous reactions that modify $\mathrm{pH}$ during subsurface and/ or sampling-related seawater entrainment. The pH's (measured at $25^{\circ} \mathrm{C}$ ) in low $\mathrm{Mg}(<5 \mathrm{mmol} / \mathrm{kg})$ samples from Vienna Woods are mildly acidic (4.2-4.9) and are within the range of values previously measured in 1995 and 2000 (Gamo et al., 1997; Fourre et al., 2006). In contrast, the pH of all PACMANUS fluid samples ranges from 2.3 to 5.9 (Table 1) and all high temperature $\left(>250{ }^{\circ} \mathrm{C}\right)$ samples (excluding those suspected of entrainment during sampling) fall within a narrow range of 2.3-3.0. This range overlaps the lowest $\mathrm{pH}$ measured at PACMANUS in 1995 (2.63 for a $268{ }^{\circ} \mathrm{C}$ fluid, Fourre et al., 2006) and is comparable to values previously reported for other arc/back-arc hydrothermal systems (Fouquet et al., 1991a, 1993; Gamo et al., 1997; Nakagawa et al., 2006; Takai et al., 2008). The low temperature NE Pual fluid (NP1) had relatively high pH (6.9).

\section{4. $\mathrm{H}_{2}, \mathrm{H}_{2} \mathrm{~S}, \mathrm{CH}_{4}, \mathrm{CO}$ and $\mathrm{CO}_{2}$}

In general, endmember concentrations of $\mathrm{H}_{2}, \mathrm{H}_{2} \mathrm{~S}, \mathrm{CH}_{4}$ and $\mathrm{CO}_{2}$ in Vienna Woods fluids are uniform and relatively low compared to the known range of MOR fluid compositions (Von Damm, 1995; German and Von Damm, 2003). At Pual Ridge, however, significant variability is evident in endmember $\mathrm{H}_{2}, \mathrm{H}_{2} \mathrm{~S}, \mathrm{CH}_{4}$ and $\mathrm{CO}_{2}$ both between vent areas and within each area (Table 2). With the exception of the high value at $\mathrm{F} 3$ vent $(306 \mu \mathrm{M})$, all endmember $\mathrm{H}_{2}$ concentrations are below $104 \mu \mathrm{M}$. Endmember $\mathrm{H}_{2}$ is generally lower in fluids with lower measured exit temperatures (such as the Satanic Mills, Snowcap, and F5 fluids) and lower endmember $\mathrm{Cl}$ (Table 2 and Fig. 5a). Endmember $\mathrm{H}_{2} \mathrm{~S}$ ranges from $1.9 \mathrm{mM}$ at Snowcap to $20.8 \mathrm{mM}$ at Fenway and is highest in fluids with lower endmember $\mathrm{Cl}$ (Fig. 5b). $\delta^{34} \mathrm{~S}_{\mathrm{H}_{2} \mathrm{~S}}$ values at PACMANUS are highly variable, with positive values $(0.0$ to $+4.4 \%$ ) at Roman and Roger's Ruins but lower values $(-2.7 \%$ to $+2.6 \%$ ) at Satanic Mills, Snowcap and Fenway. These lower values are below the published range for unsedimented hydrothermal systems $(+1.4 \%$ to $+8.6 \%$, Shanks, 2001).

Endmember $\mathrm{CO}_{2}$ values range from 4.38 to $4.48 \mathrm{mmol} /$ $\mathrm{kg}$ at Vienna Woods and are comparable to the previously reported value for the site $(6 \mathrm{mM}$, Ishibashi et al., 1996). $\delta^{13} \mathrm{C}_{\mathrm{CO}_{2}}$ values range from $-5.2 \%$ to $-5.7 \%$ and are within the range of basaltic $\mathrm{CO}_{2} \delta^{13} \mathrm{C}$ values reported near Vienna Woods $(-4.3 \%$ to $-11.3 \%$, Shaw et al., 2004). With the exception of NE Pual, all fluids at Pual Ridge have substantially higher endmember $\mathrm{CO}_{2}$ concentrations, ranging from $7.04 \mathrm{mmol} / \mathrm{kg}$ at Roger's Ruins to $274 \mathrm{mmol} / \mathrm{kg}$ at Satanic Mills (Table 2). Ishibashi et al. (1996) previously reported values of $20-40 \mathrm{mM}$ for the PACMANUS area but these data are likely minimum estimates because the samples were not acquired with gas-tight samplers. The higher $\mathrm{CO}_{2}$ concentrations found in the lower $\mathrm{Cl}$ fluids at Snowcap 


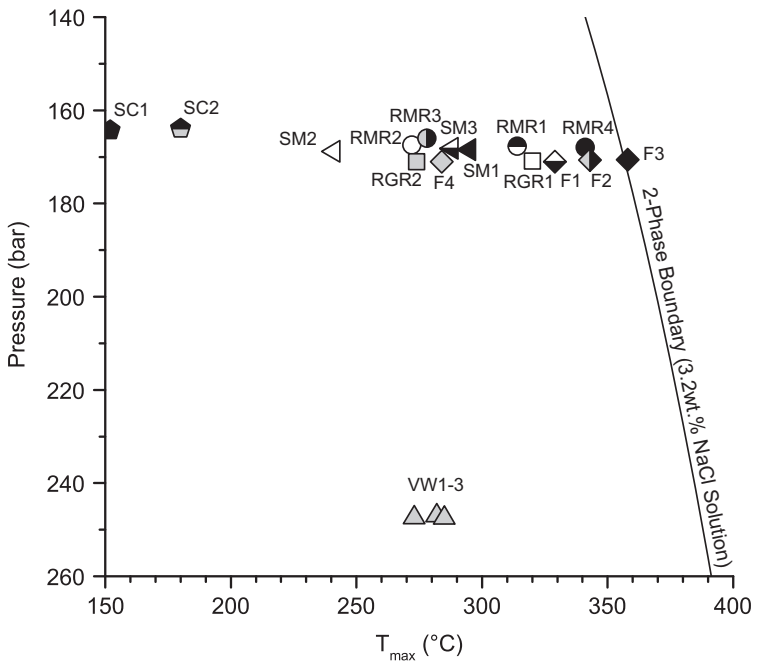

Fig. 3. Plot of vent pressures and maximum temperatures $\left(T_{\max }\right)$ for all moderate- to high-temperature fluids sampled at Vienna Woods (one symbol, VW1-3) and PACMANUS. The black line represents the two-phase boundary for a $3.2 \mathrm{wt} \% \mathrm{NaCl}$ solution (from Bischoff and Rosenbauer, 1985). Cl contents were highly variable $(517-589 \mathrm{mmol} / \mathrm{kg}$ ) between samples with similar $\mathrm{Mg}$ at F3 vent due to the vigorously boiling nature of the fluid. However, using the endmember $\mathrm{Cl}$ value $(562 \mathrm{mmol} / \mathrm{kg})$, the fluid approximates a $\sim 3.3 \mathrm{wt} \% \mathrm{NaCl}$ equivalent solution.

and Satanic Mills (Fig. 5c and Table 2) are among the highest reported to date for vent fluids (Karl et al., 1988; Butterfield et al., 1990; Sakai et al., 1990a,b; Von Damm, 1995; German and Von Damm, 2003; Lupton et al., 2006) and are comparable to those observed in black smoker fluids at the back-arc JADE site, Okinawa Trough (Sakai et al., 1990b). In addition to the higher concentrations relative to Vienna Woods, $\mathrm{CO}_{2}$ is more ${ }^{13} \mathrm{C}$-enriched at PACMANUS compared to Vienna Woods and MORB values, with endmember $\delta^{13} \mathrm{C}_{\mathrm{CO}_{2}}$ values varying from $-4.1 \%$ to $-2.3 \%$ (Table 2).

Endmember $\mathrm{CH}_{4}$ concentrations at Vienna Woods and Pual Ridge are at the lower end of known compositions from MOR systems (German and Von Damm, 2003) but are highly variable at PACMANUS, ranging from $14 \mu \mathrm{M}$ to a maximum of $85 \mu \mathrm{M}$. Higher endmember $\mathrm{CH}_{4}$ concentrations there are also associated with lower $\mathrm{Cl}$ contents (Fig. 5d). $\delta^{13} \mathrm{C}_{\mathrm{CH}_{4}}$ values (Table 2) at Pual Ridge (-7.4\% to $-15.2 \%$ ) are higher than Vienna Woods $(-20.7 \%$ to $-20.8 \%$ ), but values from both areas overlap the range observed for other unsedimented MOR hydrothermal fluids $(-8.0 \%$ to $-20.8 \%$, McCollom and Seewald, 2007). CO concentrations are also variable at PACMANUS (highest endmember $(0.15 \mu \mathrm{M})$ at $\mathrm{F} 3$ vent) but $\mathrm{CO}$ was not detected in Vienna Woods fluids (Table 2).

\section{5. $\mathrm{Cl}, \mathrm{Br}$ and $\mathrm{F}$}

While endmember $\mathrm{Cl}$ concentrations are uniformly 25-30\% higher than ambient seawater at Vienna Woods, much greater variability is evident at Pual Ridge (Table 2). Fluids at Roger's and Roman Ruins are all enriched in $\mathrm{Cl}$ relative to seawater, with endmember concentrations of $551-731 \mathrm{mmol} / \mathrm{kg}$, whereas the other vent areas are both enriched and depleted relative to seawater, reaching a minimum value of $388 \mathrm{mmol} / \mathrm{kg}$ (Table 2). Endmember $\mathrm{Br}$ and $\mathrm{Cl}$ values at both Vienna Woods and Pual Ridge correlate well with each other and the majority of fluids have $\mathrm{Br} / \mathrm{Cl}$ ratios close to that of ambient seawater (1.5, Table 3 ). In contrast to Vienna Woods fluids, which are uniformly depleted in fluoride $(\mathrm{F})$, all Pual Ridge fluids are variably enriched relative to seawater (Table 2). Endmember $F$ values at PACMANUS (up to $0.386 \mathrm{mmol} / \mathrm{kg}$ ) are the highest reported to date for seafloor hydrothermal systems (Von Damm, 1995; German and Von Damm, 2003). Fluids with higher endmember $\mathrm{F}$ at Pual Ridge also have higher
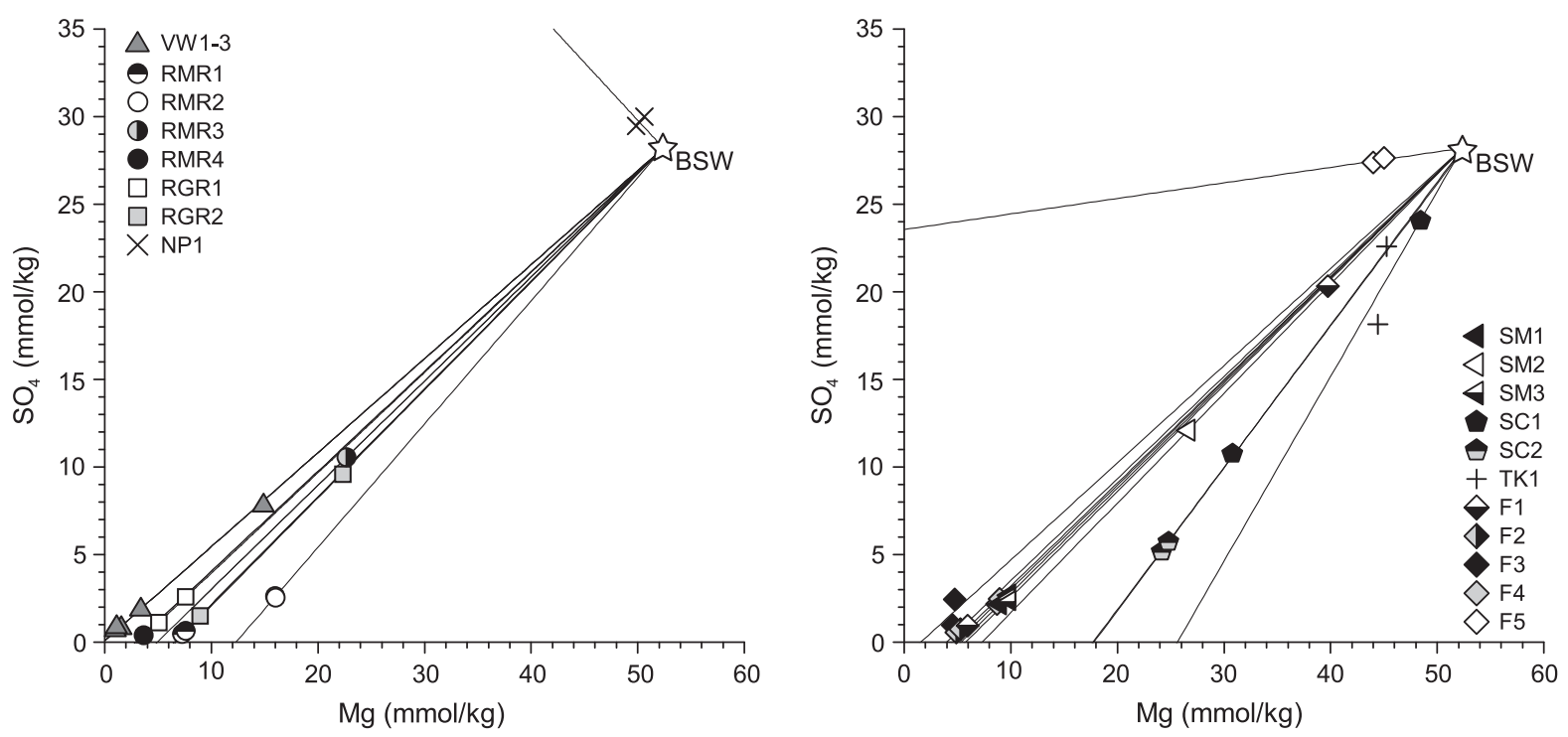

Fig. 4. Measured $\mathrm{Mg}$ vs. measured $\mathrm{SO}_{4}$ concentrations for all vent fluid samples from the Vienna Woods, PACMANUS and NE Pual vent fields. BSW is bottom seawater (denoted by star). 

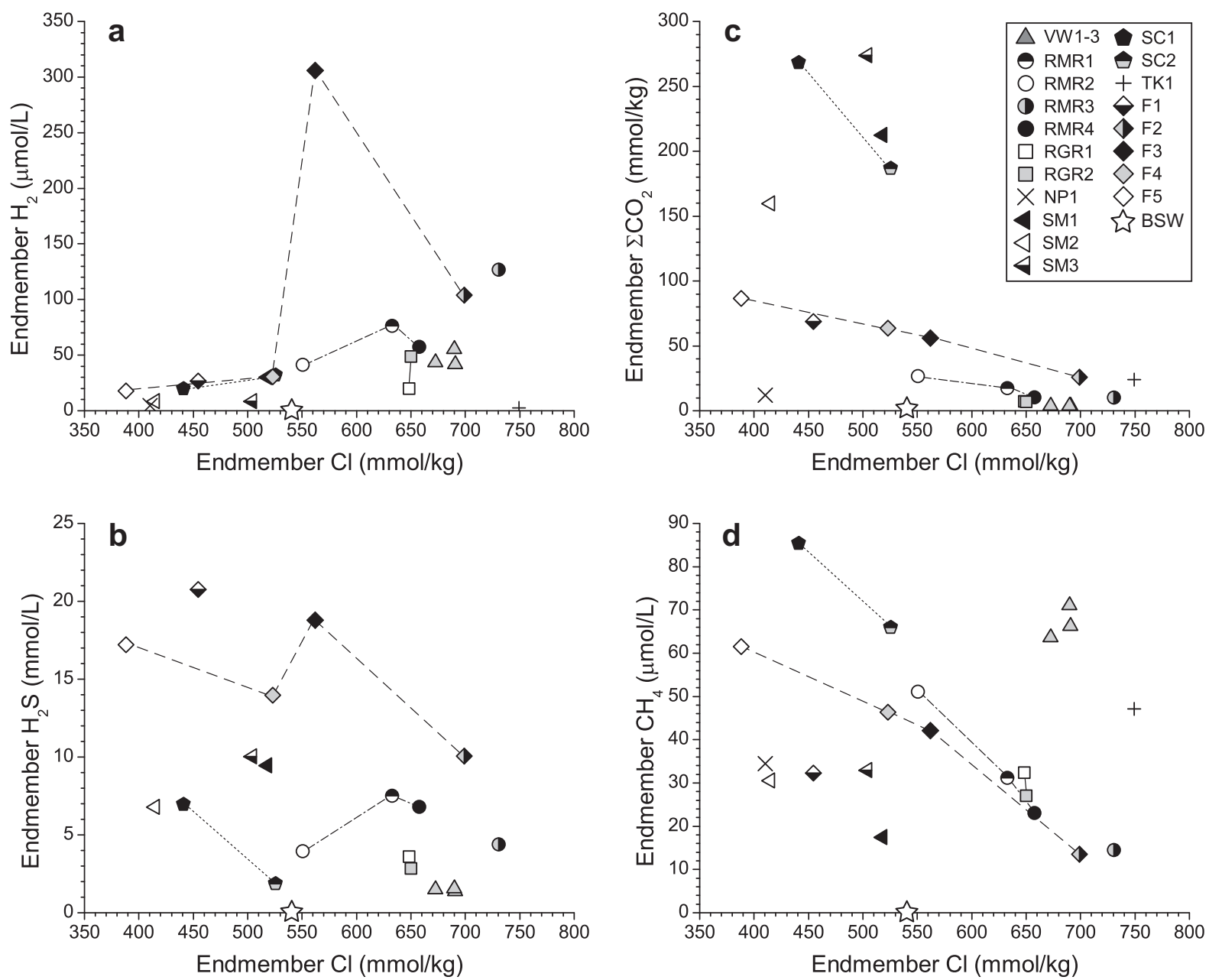

Fig. 5. Endmember $\mathrm{Cl}$ concentrations vs. endmember (a) $\mathrm{H}_{2}$, (b) $\mathrm{H}_{2} \mathrm{~S}$, (c) $\Sigma \mathrm{CO}_{2}$ and (d) $\mathrm{CH}_{4}$ concentrations for all PACMANUS, NE Pual and Vienna Woods fluids. Dashed, dot-dashed, dotted and solid lines are drawn between closely co-located vents at Fenway, Roman Ruins, Snowcap and Roger's Ruins (cf. Fig. 2). BSW, bottom seawater.

endmember $\mathrm{CO}_{2}$, with the highest concentrations of both at Snowcap, Satanic Mills and Fenway (Fig. 6).

\section{6. $\delta^{18} \mathrm{O}_{\mathrm{H}_{2} \mathrm{O}}$ and $\delta \mathrm{D}_{\mathrm{H}_{2} \mathrm{O}}$}

All vent waters at Vienna Woods have positive endmember $\delta \mathrm{D}_{\mathrm{H}_{2} \mathrm{O}}$ and $\delta^{18} \mathrm{O}_{\mathrm{H}_{2} \mathrm{O}}$ values (Table 2), resembling observations from MOR hydrothermal systems (Shanks et al., 1995; Shanks, 2001). In contrast, though all PACMANUS fluids have endmember $\delta^{18} \mathrm{O}_{\mathrm{H}_{2} \mathrm{O}}$ values greater than those of Vienna Woods, the majority of $\delta \mathrm{D}_{\mathrm{H}_{2} \mathrm{O}}$ values there are substantially lower than seawater and among the most negative found to date in seafloor hydrothermal fluids (de Ronde, 1995; Shanks et al., 1995; Gamo et al., 1997; Shanks, 2001).

\subsection{Alkalis, alkaline earths and B}

Because $\mathrm{Na}$ and other ionic species tend to co-vary with $\mathrm{Cl}$ due to charge balance constraints, concentrations are typically normalized to $\mathrm{Cl}$ to eliminate this variability (Von Damm, 1995). All fluids from both Pual Ridge and Vienna Woods have lower endmember $\mathrm{Na} / \mathrm{Cl}$ ratios than seawater (0.87), ranging from $0.50-0.79$ at Pual Ridge and $0.74-0.75$ at Vienna Woods (Table 3 ).

Both absolute and $\mathrm{Cl}$-normalized endmember $\mathrm{K}, \mathrm{Rb}$ and Cs concentrations are much higher in Pual Ridge fluids relative to Vienna Woods (Tables 2 and 3), consistent with the higher abundances of these elements in EMVZ crustal rock relative to the MSC (Sinton et al., 2003). The maximum endmember $\mathrm{K}$ concentration at Pual Ridge (96.8 mmol/kg, vs. $21.2 \mathrm{mmol} / \mathrm{kg}$ at Vienna Woods) is one the highest reported to date and consistent with previously reported endmember values at PACMANUS (80-90 mmol/ $\mathrm{kg}$, Gamo et al., 1996a). Pual Ridge fluids have a broader range of endmember $\mathrm{Li}$ concentrations $(0.475-1.33 \mathrm{mmol} /$ $\mathrm{kg})$ than Vienna Woods $(1.07-1.16 \mathrm{mmol} / \mathrm{kg})$ but endmember $\mathrm{Li} / \mathrm{Cl}$ ratios from both areas overlap (Table 3 ).

With the exception of NE Pual, which has an endmember $\mathrm{Ca}$ concentration of $84.8 \mathrm{mmol} / \mathrm{kg}$, Pual Ridge fluids have much lower Ca contents $(0.508-31.8 \mathrm{mmol} / \mathrm{kg}) \mathrm{com}-$ pared to Vienna Woods $(70.7-80.9 \mathrm{mmol} / \mathrm{kg})$ and this is also apparent on a Cl-normalized basis (Table 3). This disparity was evident in the compositions of samples taken in 1995 , where endmembers of $\sim 18$ and $\sim 80 \mathrm{mmol} / \mathrm{kg}$ were 
Table 3

Selected elemental ratios at zero Mg concentration from the Vienna Woods, PACMANUS and NE Pual vent fields, Manus Basin.

\begin{tabular}{|c|c|c|c|c|c|c|c|c|c|c|c|c|c|c|c|}
\hline $\begin{array}{l}\text { Vent field } \\
\text { Area: Vent }\end{array}$ & $\begin{array}{l}T_{\max } \\
\left({ }^{\circ} \mathrm{C}\right)\end{array}$ & $\begin{array}{l}\mathrm{Mg}_{\text {min }} \\
(\mathrm{mm})\end{array}$ & $\begin{array}{l}\mathrm{pH}_{\min } \\
\left(25^{\circ} \mathrm{C}\right)\end{array}$ & $\mathrm{Na} / \mathrm{Cl}$ & $\mathrm{Ca} / \mathrm{Cl}$ & $\mathrm{K} / \mathrm{Cl}$ & $\begin{array}{l}\mathrm{Sr} / \mathrm{Cl} \\
\left(\times 10^{-3}\right)\end{array}$ & $\begin{array}{l}\mathrm{Li} / \mathrm{Cl} \\
\left(\times 10^{-3}\right)\end{array}$ & $\begin{array}{l}\mathrm{Rb} / \mathrm{Cl} \\
\left(\times 10^{-3}\right)\end{array}$ & $\begin{array}{l}\mathrm{Cs} / \mathrm{Cl} \\
\left(\times 10^{-6}\right)\end{array}$ & $\begin{array}{l}\mathrm{Br} / \mathrm{Cl} \\
\left(\times 10^{-3}\right)\end{array}$ & $\begin{array}{l}\mathrm{B} / \mathrm{Cl} \\
\left(\times 10^{-3}\right)\end{array}$ & $\begin{array}{l}\mathrm{Fe} / \mathrm{Cl} \\
\left(\times 10^{-3}\right)\end{array}$ & $\begin{array}{l}\mathrm{Mn} / \mathrm{Cl} \\
\left(\times 10^{-3}\right)\end{array}$ & $\mathrm{Fe} / \mathrm{Mn}$ \\
\hline \multicolumn{16}{|c|}{ Vienna Woods } \\
\hline VW1 & 282 & 1.44 & 4.4 & 0.74 & 0.12 & 0.031 & 0.35 & 1.6 & 0.026 & 0.42 & 1.5 & 0.34 & 0.22 & 0.51 & 0.44 \\
\hline VW2 & 273 & 1.02 & 4.2 & 0.74 & 0.12 & 0.031 & 0.36 & 1.7 & 0.027 & 0.41 & 1.5 & 0.36 & 0.24 & 0.53 & 0.45 \\
\hline VW3 & 285 & 1.11 & 4.7 & 0.75 & 0.11 & 0.030 & 0.33 & 1.6 & 0.026 & 0.39 & 1.5 & 0.28 & 0.19 & 0.31 & 0.59 \\
\hline \multicolumn{16}{|c|}{ PACMANUS } \\
\hline \multicolumn{16}{|c|}{ Roman Ruins } \\
\hline RMR1 & 314 & 7.26 & 2.3 & 0.75 & 0.031 & 0.13 & 0.12 & 1.8 & 0.12 & 4.3 & 1.5 & 3.3 & 10 & 6.3 & 1.6 \\
\hline RMR2 & 272 & 15.9 & 2.3 & 0.76 & 0.019 & 0.12 & 0.089 & 1.6 & 0.11 & 4.1 & 1.5 & 3.2 & 2.6 & 6.0 & 0.43 \\
\hline RMR3 & 278 & 6.39 & 2.5 & 0.74 & 0.035 & 0.13 & 0.11 & 1.8 & 0.12 & 4.3 & 1.5 & 3.0 & 11 & 6.5 & 1.6 \\
\hline RMR4 & 341 & 3.63 & 2.6 & 0.76 & 0.035 & 0.12 & 0.13 & 1.7 & 0.12 & 3.7 & 1.6 & 2.6 & 10 & 4.6 & 2.3 \\
\hline \multicolumn{16}{|c|}{ Roger's Ruins } \\
\hline RGR1 & 320 & 4.24 & 2.7 & 0.75 & 0.042 & 0.13 & 0.17 & 1.4 & 0.12 & 3.3 & 1.5 & 2.0 & 7.2 & 4.3 & 1.7 \\
\hline RGR2 & 274 & 8.61 & 2.6 & 0.75 & 0.038 & 0.12 & 0.15 & 1.4 & 0.12 & 3.3 & 1.5 & 1.9 & 6.0 & 4.0 & 1.505 \\
\hline \multicolumn{16}{|l|}{ Satanic Mills } \\
\hline SM1 & 295 & 8.16 & 2.6 & 0.77 & 0.025 & 0.13 & 0.11 & 1.5 & 0.14 & 4.3 & 1.5 & 2.5 & 6.6 & 5.1 & 1.3 \\
\hline SM2 & 241 & 16.9 & 2.4 & 0.79 & 0.0087 & 0.13 & 0.016 & 1.5 & 0.12 & 4.3 & 1.5 & 2.7 & 3.8 & 5.8 & 0.66 \\
\hline SM3 & 288 & 9.72 & 2.5 & 0.77 & 0.027 & 0.14 & 0.13 & 1.4 & 0.14 & 4.3 & 1.5 & 2.2 & 2.4 & 4.6 & 0.53 \\
\hline \multicolumn{16}{|l|}{ Snowcap } \\
\hline $\mathrm{SC} 1$ & 152 & 30.8 & 4.6 & 0.78 & 0.0012 & 0.11 & -0.053 & 1.6 & 0.10 & 3.7 & 1.5 & 1.8 & 0.17 & 5.8 & 0.030 \\
\hline $\mathrm{SC} 2$ & 180 & 24.2 & 3.4 & 0.78 & 0.0064 & 0.11 & 0.047 & 1.7 & 0.097 & 4.0 & 1.6 & 2.3 & 0.52 & 5.7 & 0.091 \\
\hline \multicolumn{16}{|l|}{ Tsukushi } \\
\hline TK1 & 62 & 44.4 & 5.7 & 0.67 & 0.032 & 0.11 & 0.14 & 1.8 & 0.10 & 3.8 & 1.7 & -0.028 & 1.1 & 5.2 & 0.21 \\
\hline \multicolumn{16}{|l|}{ Fenway } \\
\hline F1 & 329 & 5.84 & 2.6 & 0.72 & 0.032 & 0.13 & 0.21 & 1.6 & 0.13 & 4.7 & 1.6 & 3.1 & 19 & 6.0 & 3.1 \\
\hline F2 & 343 & 4.66 & 2.7 & 0.69 & 0.039 & 0.13 & 0.17 & 1.6 & 0.14 & 4.8 & 1.6 & 2.8 & 21 & 6.8 & 3.1 \\
\hline F3 & 358 & 4.52 & 2.7 & 0.71 & 0.040 & 0.14 & 0.17 & 1.6 & 0.13 & 4.7 & 1.6 & 2.9 & 21 & 6.8 & 3.1 \\
\hline F4 & 284 & 8.69 & 2.5 & 0.72 & 0.037 & 0.13 & 0.16 & 1.6 & 0.13 & 4.8 & 1.6 & 2.9 & 16 & 6.9 & 2.3 \\
\hline F5 & 80 & 44.0 & 4.9 & 0.62 & 0.082 & 0.11 & 0.45 & 1.5 & 0.14 & 4.0 & 1.9 & -1.4 & 12 & 6.0 & 2.0 \\
\hline \multicolumn{16}{|l|}{ NE Pual } \\
\hline NP1 & 35 & 49.9 & 6.9 & 0.50 & 0.21 & 0.072 & 0.86 & 1.2 & 0.070 & 3.8 & 1.4 & -14 & 6.4 & 10 & 0.62 \\
\hline Bottom SW & 3 & 52.4 & 7.9 & 0.87 & 0.019 & 0.018 & 0.17 & 0.052 & 0.0024 & 0.0043 & 1.5 & 0.79 & $<0.001$ & $<0.001$ & - \\
\hline
\end{tabular}

All ratios are on a molar basis. $T_{\max }$, max. observed temperature at vent; $\mathrm{SW}$, seawater; $\mathrm{Mg}_{\min }$, lowest $\mathrm{Mg}$ concentration for vent fluid; $\mathrm{pH}_{\text {min }}$, lowest $\left(25^{\circ} \mathrm{C}\right) \mathrm{pH}$ for vent fluid.

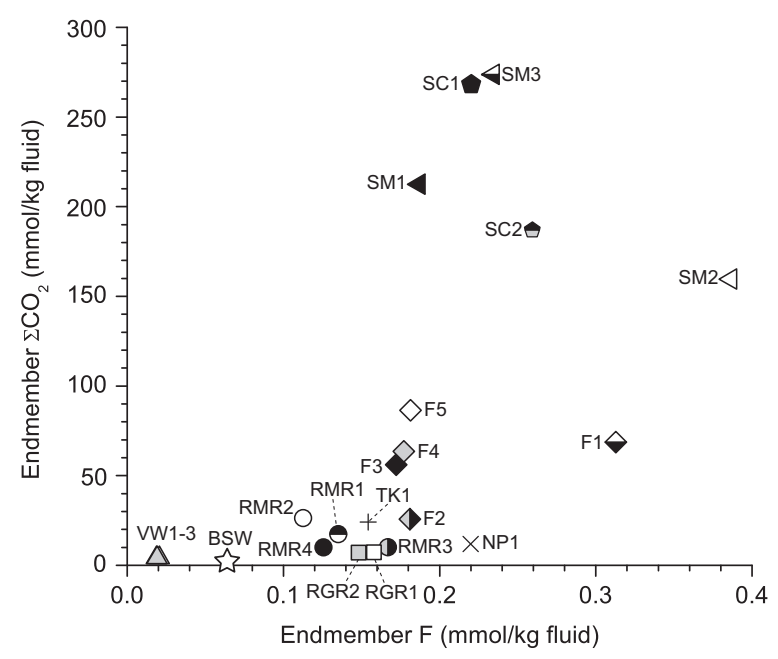

Fig. 6. Endmember F vs. endmember $\Sigma \mathrm{CO}_{2}$ concentrations for all PACMANUS, NE Pual and Vienna Woods fluids. BSW, bottom seawater.

reported for PACMANUS and Vienna Woods, respectively (Gamo et al., 1996a). There is substantial inter- and intra-field variability at PACMANUS with some fluids even having lower endmember $\mathrm{Ca} / \mathrm{Cl}$ ratios than seawater (Table 3). The highest endmember $\mathrm{Ca}$ concentrations and $\mathrm{Ca} / \mathrm{Cl}$ ratios at Pual Ridge are from the low temperature F5 and NP1 fluids (Tables 2 and 3).

Endmember Sr concentrations are also much lower at PACMANUS compared to Vienna Woods (Tables 2 and 3), with NE Pual having anomalously high Sr. Sr exhibits similar variability to $\mathrm{Ca}$ in Pual Ridge fluids and the elements tend to co-vary on a Cl-normalized basis (Table 3 ). At Snowcap, measured $\mathrm{Sr}$ values extrapolate to an apparent negative endmember of $-23.4 \mu \mathrm{mol} / \mathrm{kg}$. This indicates substantial non-conservative behavior as $\mathrm{Sr}$ concentrations are depleted below that expected for mixing of a fluid devoid of $\mathrm{Sr}$ and Sr-replete seawater. As with $\mathrm{Ca}$, the highest endmember $\mathrm{Sr}$ concentrations and $\mathrm{Sr} / \mathrm{Cl}$ ratios at Pual Ridge are also at F5 and NP1 vents (Tables 2 and 3). Endmember ${ }^{87} \mathrm{Sr} /{ }^{86} \mathrm{Sr}$ ratios for PACMANUS fluids (Table 2 and Fig. 7) range from 0.69768 to 0.70429 and are lower than the Vienna Woods endmember (0.70435). A calculated endmember ratio of 0.69768 is below that possible for terrestrial materials (Banner, 2004), and therefore cannot reflect an existing composition. This is likely due to modification of the $\mathrm{Mg} / \mathrm{Sr}$ ratio by the $\mathrm{Sr}$ loss noted above. 


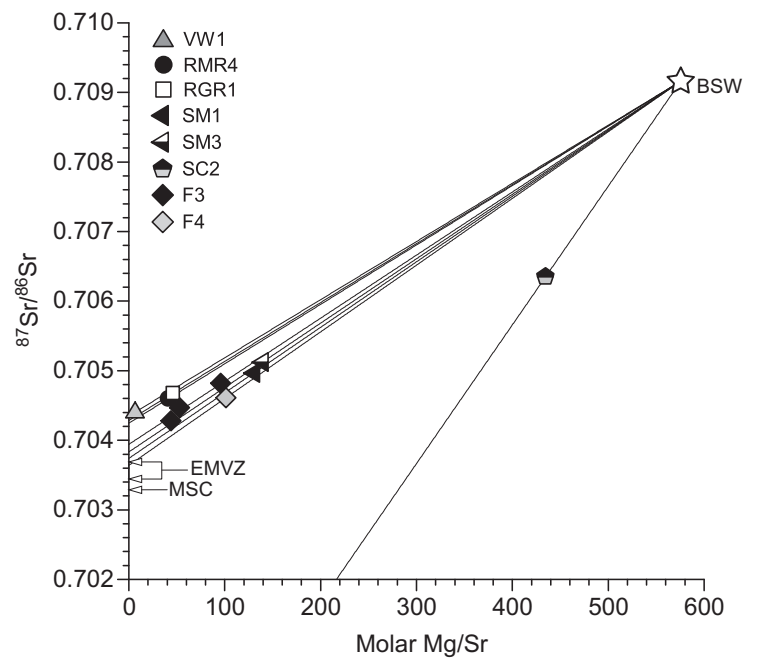

Fig. 7. Measured ${ }^{87} \mathrm{Sr} /{ }^{86} \mathrm{Sr}$ ratios vs. measured $\mathrm{Mg} / \mathrm{Sr}$ ratios for select Vienna Woods and PACMANUS fluids. Lines of extrapolation from bottom seawater (BSW) to zero $\mathrm{Mg} / \mathrm{Sr}$ endmember ratios are shown (Albarède et al., 1981). The range of ${ }^{87} \mathrm{Sr} /{ }^{86} \mathrm{Sr}$ ratios for Pual Ridge/EMVZ lavas (0.703446-0.703690, Kamenetsky et al., 2001; Marty et al., 2001) are shown by arrows, with Manus Spreading Center (MSC) basalt $(0.703275$, Sinton et al., 2003) lying just below this range. The SC1 vent fluid extrapolates to a ratio below that possible for modern terrestrial materials (Banner, 2004) — an artifact of the high measured $\mathrm{Mg} / \mathrm{Sr}$ ratio. $\mathrm{Sr}$ loss due to co-precipitation in anhydrite is non-fractionating (Michard et al., 1984), and would increase measured $\mathrm{Mg} / \mathrm{Sr}$ without changing measured ${ }^{87} \mathrm{Sr} /{ }^{86} \mathrm{Sr}$ ratios.

As shown in Tables 2 and 3, B is uniformly depleted relative to seawater $(0.426 \mathrm{mmol} / \mathrm{kg})$ in Vienna Woods fluids but highly enriched in high temperature fluids at Pual Ridge (up to $2.17 \mathrm{mmol} / \mathrm{kg}$ ). These upper values are high relative to MOR hydrothermal fluids (German and Von Damm, 2003), but within the range observed in other back-arc vent fluids (Ishibashi and Urabe, 1995). All low temperature fluids at Pual Ridge (F5, TK1 and NP1) are depleted in B below the level expected for conservative mixing of a fluid devoid of $\mathrm{B}$ with B-replete seawater. These compositions therefore yield apparent negative endmember B concentrations, which, like $\mathrm{Sr}$, indicates substantial removal of $\mathrm{B}$ prior to venting (Table 2).

\section{8. $\mathrm{Fe}, \mathrm{Mn}, \mathrm{Al}$ and $\mathrm{SiO}_{2}$}

Vienna Woods fluids were either clear or gray in color in 2006, which is consistent with the uniformly low endmember Fe (0.12-0.17 mmol/kg, Table 2). Endmember Fe contents of Pual Ridge vent fluids are generally much higher and range from $0.076 \mathrm{mmol} / \mathrm{kg}$ at Snowcap to $14.6 \mathrm{mmol} /$ $\mathrm{kg}$ at Fenway. This upper value is high compared to most MOR vent fluids to date (Butterfield and Massoth, 1994; Von Damm, 1995; Charlou et al., 2002; Gallant and Von Damm, 2006). Fluids with the highest endmember Fe contents (F2 and F3 at Fenway) also have the highest measured temperatures but $\mathrm{Cl}$ values $<30 \%$ higher than seawater (Tables 1 and 2). There is also substantial variability between and within vent areas at Pual Ridge, with higher $\mathrm{Mg}$ fluids typically yielding lower endmember Fe values on a $\mathrm{Cl}$-normalized basis (Table 3 ).

All Pual Ridge fluids are greatly enriched in Mn relative to Vienna Woods (Table 2), with endmembers ranging from 2.3 to $4.8 \mathrm{mmol} / \mathrm{kg}$. Similar to Fe, such $\mathrm{Mn}$ values are also among the highest reported for vent fluids to date and similar to values reported in other back-arc systems (Ishibashi and Urabe, 1995; Von Damm, 1995; German and Von Damm, 2003; Takai et al., 2008). In contrast to Fe, however, there is less variability in Mn between vent areas or within them. While endmember $\mathrm{Al}$ contents at Vienna Woods are relatively uniform $(6.6-7.5 \mu \mathrm{mol} / \mathrm{kg})$, there is a much greater range in high temperature Pual Ridge fluids $(2.2-14.6 \mu \mathrm{mol} / \mathrm{kg})$. Samples from NP1 had similar Al enrichments to hotter Pual Ridge fluids and yielded an endmember concentration of $69 \mu \mathrm{mol} / \mathrm{kg}$. Endmember $\mathrm{SiO}_{2}$ concentrations are also variable at Pual Ridge (11.3$23.9 \mathrm{mmol} / \mathrm{kg}$ ) compared to Vienna Woods (14.6$15.3 \mathrm{mmol} / \mathrm{kg}$ ), (Table 2). Previous samples taken at Vienna Woods and PACMANUS in 1995 indicated endmember values of $\sim 15 \mathrm{mM}$ and $\sim 16 \mathrm{mM}$, respectively (Gamo et al., 1996a).

\section{DISCUSSION}

Models that describe convective hydrothermal systems driven by magmatic heat sources share several basic features and processes regardless of host rock (substrate) composition and tectonic setting. Seawater is typically assumed to enter the crust via a diffuse and poorly constrained 'recharge' zone and is subsequently heated to progressively higher temperatures. The hottest part of the hydrothermal flow path - the 'reaction' or 'root' zone - is most likely adjacent to or above the magmatic intrusion. When buoyancy forces are sufficient to expel high temperature fluids from the hydrothermal reservoir, fluids rise toward the seafloor through a 'discharge' or 'upflow' zone (Alt and Bach, 2003). Processes that can modify the composition of black smoker fluids during transit through such systems include water-rock (and/or sediment) interaction, phase separation, input of magmatic volatile species, conductive cooling and subsurface mixing with seawater within the crustal aquifer (Alt, 1995; Von Damm, 1995; German and Von Damm, 2003).

Given the similarity of hydrothermal interactions between seawater and basalt, andesite and rhyolite under experimental conditions (Bischoff and Dickson, 1975; Mottl and Holland, 1978; Seyfried and Bischoff, 1981; Hajash and Chandler, 1982; Shiraki et al., 1987; Ogawa et al., 2005), processes of $\mathrm{Mg}$ fixation and anhydrite precipitation are expected to control $\mathrm{Mg}, \mathrm{Ca}$ and $\mathrm{SO}_{4}$ abundance during recharge of seawater into the crust at both the Pual Ridge and Vienna Woods vent fields. Similarly, the abundances of major elements $(\mathrm{Na}, \mathrm{Ca})$ are expected to be buffered by fluid-mineral equilibria under reaction zone conditions, albeit at potentially different abundances depending on the mineral compositions involved (Seyfried, 1987; Butterfield et al., 2003). In addition, phase separation should influence the abundances of elements if $P-T$ conditions within the 
hydrothermal reservoir reach the 2-phase boundary. Degassing of volatiles from a magma body and subsequent entrainment by circulating fluids most likely occurs near the reaction zone in close proximity to the magma. Because of the weak acid nature of MORB-derived volatiles (predominantly $\mathrm{CO}_{2}$ ), this process does not significantly alter the acidity of high temperature fluids in typical mid-ocean ridge (MOR) systems (Butterfield et al., 2003). However, felsic-hosted magmatic-hydrothermal systems are likely to differ substantially in this respect because degassed volatile phases containing $\mathrm{SO}_{2}$ and $\mathrm{HCl}$ can be far more acidic (Yang and Scott, 2006). Significant modification of high temperature fluids by subsurface seawater entrainment and mixing has been recognized in MOR sites, such as the TAG hydrothermal mound on the Mid-Atlantic Ridge (Edmond et al., 1995; Tivey et al., 1995; Gamo et al., 1996c), North Cleft on the Juan de Fuca Ridge (Butterfield and Massoth, 1994) and Kairei Field, Central Indian Ridge (Gallant and Von Damm, 2006) and depends on the hydrologic regime in the 'upflow' zone.

In the following discussion we present evidence for the above processes in Manus Basin hydrothermal fluids. Furthermore, we show that the compositions of fluids at Pual Ridge have a highly complex evolution involving most, if not all, of these processes occurring either sequentially or simultaneously. To illustrate this complexity, Fig. 8 shows the proposed evolution of a hypothetical $\sim 360{ }^{\circ} \mathrm{C}$ source fluid similar to that at the Fenway area of the PACMANUS vent field.

\subsection{Influence of water/rock reaction and substrate composition on fluid compositions}

\subsubsection{Fluid-mineral equilibria}

$\mathrm{Ca}$ and $\mathrm{Na}$, whose concentrations are controlled by temperature and pressure dependant equilibrium reactions involving plagioclase minerals (Berndt et al., 1989; Berndt and Seyfried, 1993), exhibit similar trends in Manus Basin fluids to MOR hydrothermal systems. While few experimental studies have examined felsic rock-seawater interactions under hydrothermal conditions, early experimental work has demonstrated that seawater interactions with more silicic rock compositions (rhyolite and andesite) broadly resemble those with basalt for many of these 'solubility-controlled' species (Hajash and Chandler, 1982; Shiraki et al., 1987). Endmember $\mathrm{Na} / \mathrm{Cl}$ ratios from Pual Ridge fluids overlap those at Vienna Woods and all are lower than the seawater ratio, consistent with the removal of $\mathrm{Na}$ during albitization (Table 3). Though absolute $\mathrm{Ca}$ abundances in fluids from Pual Ridge have been variably modified by subsurface anhydrite deposition or dissolution (see below), endmember $\mathrm{Ca} / \mathrm{Cl}$ ratios calculated from fluids with low $\mathrm{Mg}(<5 \mathrm{mmol} / \mathrm{kg}$, Table 2$)$ are greater than seawater, which is consistent with $\mathrm{Ca}$ addition from the destruction of anorthite. Endmember $\mathrm{Ca} / \mathrm{Cl}$ and $\mathrm{Na} / \mathrm{Cl}$ ratios at Pual Ridge are within the range generally observed in unsedimented hydrothermal systems in MOR settings (Gallant and Von Damm, 2006), suggesting that the compositional differences between the host rock at Pual Ridge and MORB do not influence these elements substantially.

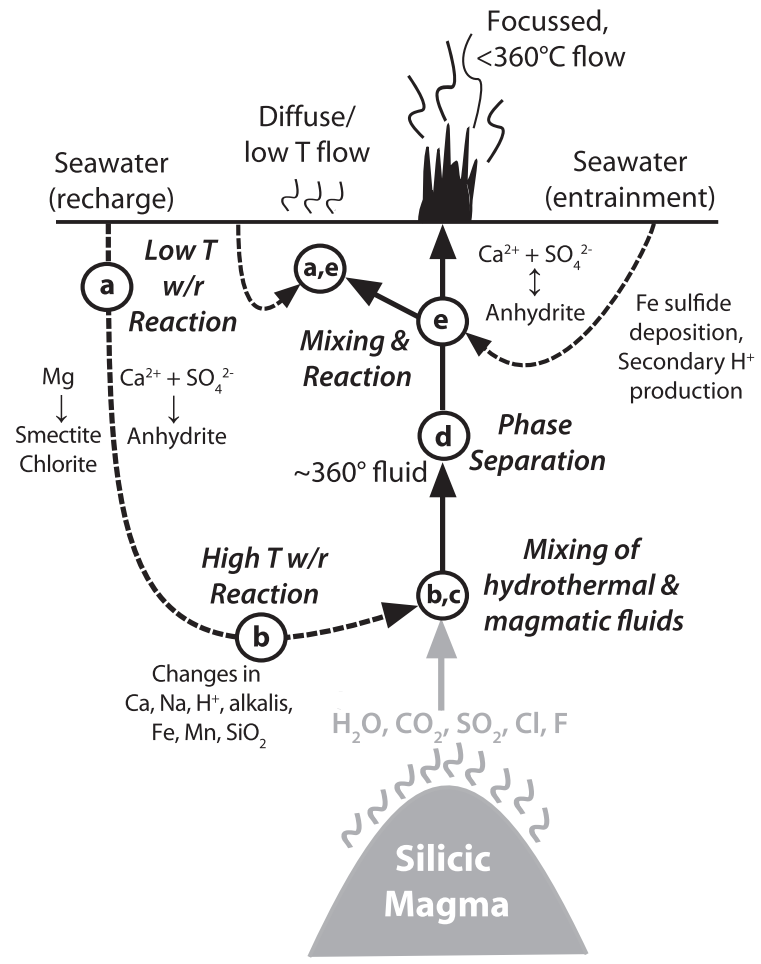

Fig. 8. Cartoon illustrating the formation and evolution of a hypothetical $\sim 360^{\circ} \mathrm{C}$ source fluid (similar to Fenway) at PACMANUS. Dashed black lines indicate solely seawater-derived fluids, solid gray lines denote magmatic fluid phases and solid black lines denote mixtures of both that rise to eventually exit on the seafloor as either focused or diffuse/low temperature venting. Cold seawater enters the crust via recharge zones and with progressive heating first undergoes low temperature $(T)$ water/rock $(w / r)$ reactions (denoted as (a)) such as fixation of $\mathrm{Mg}$, alkalis and $\mathrm{B}$, and anhydrite precipitation (Alt, 1995). Near the reaction or root zone of the hydrothermal reservoir, high temperature reactions (denoted as (b)) such as albitization, mobilization of alkalis, Fe and $\mathrm{Mn}$, and modification of fluid $\delta \mathrm{D}_{\mathrm{H}_{2} \mathrm{O}}$ and $\delta^{18} \mathrm{O}_{\mathrm{H}_{2} \mathrm{O}}$ values, occur regardless of the presence or absence of magmatic inputs. Input, mixing and reaction of an acidic magmatic fluid phase (c) likely occurs nearest the magma intrusion and is accompanied by subsequent high temperature reactions of the mixed fluid with the host rock (e.g. deposition of magma-derived $\mathrm{SO}_{4}$ as anhydrite, titration of acidity and further metal mobilization). Phase separation (d) and partial/ complete segregation of resulting high and low chlorinity phases either occurs by decompression during upflow, or anywhere else that the 2-phase boundary is intercepted within the hydrothermal reservoir. During upflow, the resulting $360{ }^{\circ} \mathrm{C}$ source fluid mixes with crustal seawater and is cooled to yield a lower temperature focused fluid. Reactions occurring during mixing (e) include deposition of admixed seawater $\mathrm{SO}_{4}$ as anhydrite (or in fluids below $\sim 150{ }^{\circ} \mathrm{C}$, dissolution of previously formed anhydrite deposits) and generation of secondary acidity by Fe sulfide deposition. In the case of diffuse/low temperature fluids, additional low temperature water/rock reactions, such as B fixation, may also occur prior to venting at the seafloor.

In addition to $\mathrm{Ca}$ and $\mathrm{Na}, \mathrm{Sr}$ abundance in hydrothermal fluids is also considered to be solubility-controlled (Berndt et al., 1988; Von Damm, 1988) and fluid compositions from the Manus Basin support control of dissolved $\mathrm{Sr}$ 
abundance by reactions involving plagioclase minerals. Despite higher crustal abundances of $\mathrm{Sr}$ in crustal rocks of the EMVZ (Sinton et al., 2003), endmember $\mathrm{Sr} / \mathrm{Cl}$ ratios (calculated from fluids with lowest $\mathrm{Mg}$ ) at Pual Ridge are lower than corresponding ratios at Vienna Woods. However, like $\mathrm{Ca} / \mathrm{Cl}$ and $\mathrm{Na} / \mathrm{Cl}$, endmember $\mathrm{Sr} / \mathrm{Cl}$ and $\mathrm{Sr} / \mathrm{Ca}$ ratios at Vienna Woods and in low Mg fluids at Pual Ridge are within the known range of MOR hydrothermal systems (Berndt et al., 1988; Gallant and Von Damm, 2006). As stated below, the variability in endmember ${ }^{87} \mathrm{Sr} /{ }^{86} \mathrm{Sr}$ ratios at PACMANUS (Fig. 7) is an artifact of the effect of Sr loss during seawater entrainment on the $\mathrm{Mg} / \mathrm{Sr}$ extrapolation method (see below). However, endmember ratios at Vienna Woods (0.70435) and in low Mg fluids at PACMANUS (0.70394-0.70428) are consistent with a predominantly rock-derived source of Sr. Crustal ${ }^{87} \mathrm{Sr} /{ }^{86} \mathrm{Sr}$ ratios from Pual Ridge and surrounding areas fall in a narrow range of $0.703446-0.703690$, while MSC basalts have a ratio of 0.703275 (Kamenetsky et al., 2001; Marty et al., 2001; Sinton et al., 2003). A possible explanation for the slightly higher ${ }^{87} \mathrm{Sr} /{ }^{86} \mathrm{Sr}$ ratios in fluids least affected by extrapolation/entrainment artifacts is that the $\mathrm{Sr}$ represents a mixture of seawater- and rock-derived Sr. Berndt et al. (1988) proposed a fluid reaction path model to explain the relationship between $\mathrm{Sr}$ abundance and ${ }^{87} \mathrm{Sr} /{ }^{86} \mathrm{Sr}$ ratios in MOR vent fluids whereby incomplete seawater $\mathrm{Sr}$ removal occurs during recharge (by anhydrite deposition), followed by subsequent addition of rock-derived $\mathrm{Sr}$ by dissolution of $\mathrm{Ca}-$ and Sr-bearing primary plagioclase minerals in high temperature reaction zones. Precipitation during recharge would remove $\mathrm{Sr}$ without changing its isotopic composition while subsequent addition of rock $\mathrm{Sr}$ from plagioclase dissolution would give rise to decreased ${ }^{87} \mathrm{Sr} /{ }^{86} \mathrm{Sr}$ ratios and increased $\mathrm{Sr}$ concentrations in endmember fluids.

Despite the high temperature of some fluids at PACMANUS (e.g. $358^{\circ} \mathrm{C}$ at F3), none of the sampled fluids are devoid of $\mathrm{Mg}$ as is typical at Vienna Woods and other MOR hydrothermal fluids. While we argue below (Section 5.4) that the majority of $\mathrm{Mg}$ in Pual Ridge fluids is added as a result of subsurface/sampling-related seawater entrainment, there may be a relatively minor component that reflects the true $\mathrm{Mg}$ composition of the endmember fluid. This is best exemplified by the hottest fluid (F3 vent) at Pual Ridge. Two of the three samples from F3 have consistent measured $\mathrm{Mg}$ (4.52 and $4.74 \mathrm{mmol} / \mathrm{kg}$, Table 1) and temperatures (358 and $356{ }^{\circ} \mathrm{C}$, respectively). It is unlikely that these concentrations reflect entrainment of identical amounts of seawater during sampling, and they are greater than can be attributed to the dead volume of the IGT samplers (which accounts for $<1.6 \mathrm{mmol} / \mathrm{kg} \mathrm{Mg}$ in any given IGT sample). This implies a $\mathrm{Mg}$ content of $\sim 3 \mathrm{mmol} / \mathrm{kg}$ as the F3 fluid exited the seafloor at a temperature that places it on the boiling curve at seafloor pressure. It is unreasonable to conclude that this $\mathrm{Mg}$ could be derived from seawater mixing prior to venting as the required $\sim 5 \%$ mix of seawater would cool the fluid by $\sim 20^{\circ} \mathrm{C}$ below the two-phase boundary. The possibility exists that admixing of small amounts of a hotter seawater-like fluid occurred deep in the system and boiling occurred in response to decompression during upflow, but it is hard to envision a scenario whereby Mg-replete seawater persists in the deep-seated reaction zone of such a hot and active system. An alternative explanation to account for this small, but significant concentration of $\mathrm{Mg}$, is that it reflects the enhanced solubility of $\mathrm{Mg}$-aluminosilicates at the exceedingly low $\mathrm{pH}$ of this fluid (2.7). Indeed, the solubility of $\mathrm{Mg}$ in hydrothermal systems in general, can be represented by the reaction:

$$
\begin{aligned}
& \mathrm{Mg}^{2+}+4 / 3 \mathrm{SiO}_{2(\mathrm{aq})}+4 / 3 \mathrm{H}_{2} \mathrm{O} \\
& =1 / 3 \mathrm{Mg}_{3} \mathrm{Si}_{4} \mathrm{O}_{10}(\mathrm{OH})_{2}+2 \mathrm{H}^{+}
\end{aligned}
$$

where talc $\left(\mathrm{Mg}_{3} \mathrm{Si}_{4} \mathrm{O}_{10}(\mathrm{OH})_{2}\right)$ is used to represent more compositionally complex phases (Seyfried, 1987). The stoichiometry of this reaction indicates that at equilibrium the activity of $\mathrm{Mg}^{2+}$ will vary inversely with the square of $\mathrm{H}^{+}$ activity. Accordingly, because vent fluids at PACMANUS are characterized by $\mathrm{pH}$ values within a range of 2-3 while $\mathrm{pH}$ typically varies from 3 to 4 in MOR systems (Von Damm, 1995; German and Von Damm, 2003), Mg activities at Pual Ridge according to Eq. (2) or similar reactions may be 2-4 orders of magnitude higher at a given temperature, pressure and silica activity (Seyfried, 1987). As such, they may approach the same order of magnitude as $\mathrm{Mg}$ contributions from sampler dead volume. Given the complex nature of $\mathrm{Mg}$ phases that may control $\mathrm{Mg}$ solubility (Seyfried, 1987) and limited thermodynamic data for these phases, however, further speculation is difficult. The observation of abundant chlorite phases throughout ODP cores taken at both Snowcap and Roman Ruins (Lackschewitz et al., 2004) suggests this group likely controls Mg solubility. Fixation of $\mathrm{Mg}$ into chlorite phases is thought to occur above $\sim 200{ }^{\circ} \mathrm{C}$ (Alt, 1995). Regardless of what the exact $\mathrm{Mg}$ content of pure endmember fluids is at Pual Ridge, the low $\mathrm{Mg}$ concentrations measured at vents like F3 suggest it is sufficiently close to the sampler dead volume contribution that the calculation of endmember compositions at the conventional zero $\mathrm{Mg}$ level is still justifiable.

\subsubsection{Alkalis and $B$}

The influence of compositional differences in host rocks between the MSC and EMVZ is most apparent in the abundances of elements that are considered highly 'mobile' during fluid-rock interactions. Field and laboratory data indicate that alkali elements are almost quantitatively partitioned into the fluid phase during high temperature fluid-rock interaction with basalt and more silicic rock compositions (Seyfried et al., 1984; Von Damm et al., 1985; Von Damm, 1990; Ogawa et al., 2005). Endmember abundances of the alkalis $\mathrm{K}, \mathrm{Rb}$ and $\mathrm{Cs}$ are highly elevated in Pual Ridge fluids relative to Vienna Woods (Tables 2 and 3) and basalt-hosted MOR systems (German and Von Damm, 2003). This is entirely consistent with the greater abundances of these incompatible elements in arc-like EMVZ crust relative to the more mafic crust of the MSC (Kamenetsky et al., 2001; Sinton et al., 2003; Paulick et al., 2004; Monecke et al., 2007). In contrast to the other mobile alkalis, large differences in endmember Li concentrations are not evident between Vienna Woods and Pual Ridge fluids (Table 2). However, limited data suggest that 
Li content of EMVZ crust ( $\sim 5-7 \mathrm{ppm})$ does not differ from that of the MSC basalt ( $\sim 5-8 \mathrm{ppm})$ to the same extent as K, $\mathrm{Rb}$ and $\mathrm{Cs}$ (Sinton et al., 2003). In addition to differences in absolute abundances, endmember molar ratios of alkalis in Pual Ridge and Vienna Woods fluids are in reasonable agreement with the alkali ratios of the host rock compositions at each location (Fig. 9). B is also greatly enriched in most Pual Ridge fluids relative to Vienna Woods, consistent with greater $\mathrm{B}$ enrichment in more silicic rock compositions and the increased influence of recycled slab material as the arc is approached (Spivack and Edmond, 1987; Ryan and Langmuir, 1993). Because of the strong affinity of B for fluids, however, we cannot exclude magmatic degassing as an additional source of B to hydrothermal fluids at Pual Ridge (Ryan and Langmuir, 1993; Arnorsson and Andresdottir, 1995; Audetat et al., 1998).

If it is assumed that the mobile alkali elements $\mathrm{Rb}$ and Cs are quantitatively leached during hydrothermal alteration and do not undergo significant secondary mineral formation, effective water/rock $(\mathrm{w} / \mathrm{r})$ ratios can be calculated if fluid and rock concentrations are known (Von Damm et al., 1985). Rb and Cs contents vary widely in the EMVZ and along the MSC, however, as a result of highly variable host rock compositions (Sinton et al., 2003). Using Rb (0.9 ppm) and Cs $(0.018 \mathrm{ppm})$ contents from dredged basalt to the south of Vienna Woods (Sinton et al., 2003), calculated $\mathrm{w} / \mathrm{r}$ ratios for fluids there vary from 0.5 to 0.6 . Using values of $\mathrm{Rb}(27 \mathrm{ppm})$ and $\mathrm{Cs}(0.8 \mathrm{ppm})$ reported for Satanic Mills lava flows (Monecke et al., 2007), higher $\mathrm{w} / \mathrm{r}$ ratios are calculated for high temperature $\left(>200^{\circ} \mathrm{C}\right)$ fluids at Pual Ridge, varying from 5 to 6 for $\mathrm{Rb}$ and 2 to 3 for Cs. Differences between these locations notwithstanding, the relatively low values combined with the alkali ratio patterns discussed above indicate hydrothermal fluids at both Pual Ridge and Vienna Woods have reacted with fresh crustal rocks under what may be considered rock-dominated conditions (Seyfried and Mottl, 1982).

\subsubsection{Quartz-fluid equilibrium and dissolved $\mathrm{SiO}_{2}$}

$\mathrm{SiO}_{2}$ contents in PACMANUS and NE Pual fluids, though highly variable, suggest considerable depths of hydrothermal circulation are possible beneath Pual Ridge. The solubility of quartz in hydrothermal solutions is a strong function of temperature, pressure and to a lesser extent, salinity. Based on the assumption of quartz-fluid equilibrium at depth, dissolved $\mathrm{SiO}_{2}$ is commonly used as an indicator of maximum $P-T$ conditions encountered by hydrothermal fluids (Fournier, 1983; Von Damm et al., 1991; Foustoukos and Seyfried, 2007a). Using extrapolated vent temperatures the quartz solubility data of Von Damm et al. (1991) and endmember $\mathrm{SiO}_{2}$ contents, RMR2 and RGR1 compositions suggest quartz-fluid equilibrium at pressure of 400-700 bar (Fig. 10). While the upper limit may be excessive, the lower limit suggests circulation depths in the vicinity of a possible magma body $\sim 2 \mathrm{~km}$ beneath the seafloor at Pual Ridge (Lee, 2003; Binns et al., 2007; Sun et al., 2007). There is a high degree of variability between co-located vents (e.g. RMR1 and RMR2), however, and shallower equilibration pressures $(<300$ bars $)$ are predicted
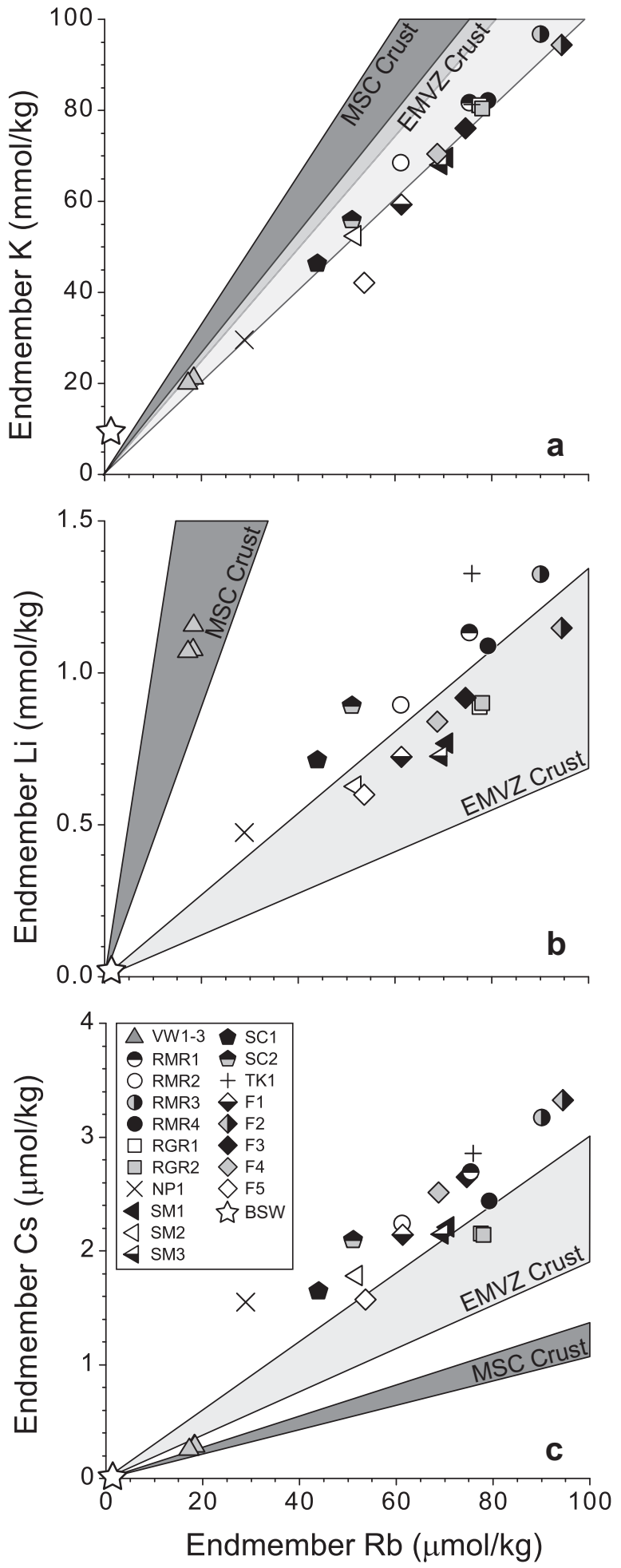

Fig. 9. Endmember K (a), Li (b) and Cs (c) concentrations vs. endmember $\mathrm{Rb}$ concentration for Vienna Woods, PACMANUS and NE Pual fluids. Light gray triangles refer to ranges of alkali/ $\mathrm{Rb}$ ratios found in Manus Spreading Center (MSC) lavas (basalts and basaltic andesites), (Sinton et al., 2003). Dark gray triangles represent corresponding ranges for EMVZ (Sinton et al., 2003) and Pual Ridge (Kamenetsky et al., 2001) lavas. 


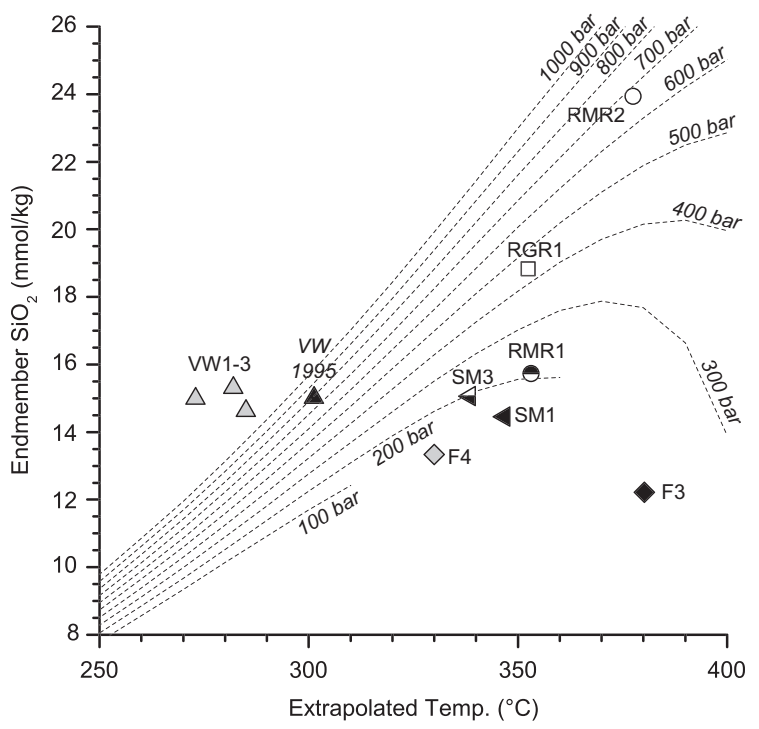

Fig. 10. Endmember $\mathrm{SiO}_{2}$ concentrations and extrapolated vent temperatures for Vienna Woods and PACMANUS fluids. The latter are calculated for vent fluids hotter than $\sim 270{ }^{\circ} \mathrm{C}$ where consistent temperatures (within $10^{\circ} \mathrm{C}$ as measured by IGT samplers) and $\mathrm{Mg}$ concentrations were obtained in repeat samples of a given vent fluid. Temperatures were extrapolated to the estimated sampler dead volume contribution by linear regression forced through bottom seawater temperature. These calculations assume no conductive cooling occurred during mixing with seawater and neglect changes in heat capacity over the temperature range of extrapolation. Quartz saturation curves from Von Damm et al. (1991) are shown for pressures of $100-1000$ bar as a function of temperature. The endmember $\mathrm{SiO}_{2}$ concentrations and maximum temperatures observed at Vienna Woods in 1995 (Gamo et al., 1997) are plotted for comparison.

for most other vents (Fig. 10). It has been suggested that the accuracy of the $\mathrm{SiO}_{2}$ geobarometer in felsic-hosted systems may be affected by re-equilibration of $\mathrm{SiO}_{2}$ with quartz-rich wall-rock during fluid upflow (Ishibashi and Urabe, 1995). Abundant subsurface quartz-bearing vesicles and veins observed in ODP drill-cores from postulated upflow zones suggest that some $\mathrm{SiO}_{2}$ deposition has occurred during ascent of fluids to the seafloor at PACMANUS (Binns et al., 2007). While this process may be responsible for lower apparent equilibrium pressures, it cannot, however, explain the extremely high silica observed at RMR2 and RGR1.

In contrast, predicted equilibrium pressures for all three vents at Vienna Woods (>1000 bar) imply an unreasonable depth of circulation there. A more plausible explanation is that extensive cooling of the Vienna Wood source fluid has occurred during upflow, as evidenced by low endmember Fe but high endmember Mn concentrations (see below, Table 2) and the high dissolved $\mathrm{SiO}_{2}$ contents are merely a relic of much higher temperatures than those venting at the seafloor. A comparison with the observations from 1995 (Fig. 10, Gamo et al., 1997) suggests that Vienna Woods fluids may be experiencing greater extents of conductive cooling with time, as maximum measured temperatures were $\sim 17^{\circ} \mathrm{C}$ hotter in 1995 but endmember $\mathrm{SiO}_{2}$ concentrations were essentially equivalent.

\subsection{4. $\mathrm{pH}$ and metal mobility}

The above observations suggest fluid-mineral buffering of major element abundances at depth. However, the $\mathrm{pH}$ of the lowest $\mathrm{Mg}$ samples at PACMANUS (2.6-2.7) is considerably more acidic than those observed during laboratory experiments that reacted seawater and rhyolite/dacite (3.5-4.5) at temperatures of $300-500^{\circ} \mathrm{C}$ (Hajash and Chandler, 1982; Shiraki et al., 1987). These experiments were conducted at 1 kbar pressure, however, which may be greater than reaction zone pressures encountered by fluids at PACMANUS where the seafloor pressure is $\sim 170$ bar. Owing to effects on fluid density and species dissociation equilibria, lower pressures tend to yield slightly lower measured $\mathrm{pH}$ values buffered by heterogeneous equilibrium reactions (Seyfried, 1987). However, uniformly low pH values, such as those at PACMANUS, are not common in basalt-hosted hydrothermal systems at similar depths (Butterfield et al., 2003). Such high acidity in black smoker fluids has only been observed in other arc and back-arc settings, such as the Vai Lili (Fouquet et al., 1991a,b, 1993) and Mariner fields (Seewald et al., 2005; Takai et al., 2008) in the Lau Basin. Low $\mathrm{pH}$ values (2.4-2.7) at Mariner are suggested to be the result of magmatic acid volatile $\left(\mathrm{SO}_{2}\right)$ degassing from underlying magmas (Seewald et al., 2005; Takai et al., 2008). As discussed below, we argue that this process contributes to the low $\mathrm{pH}$ values at PACMANUS also. In contrast, the much higher $\mathrm{pH}$ of Vienna Woods fluids (4.4 4.7 ) is more consistent with buffering by fluid-rock interactions alone.

The influence of acidity is apparent in the high $\mathrm{Fe}$ and Mn contents of PACMANUS fluids. Experiments have demonstrated that $\mathrm{Fe}$ and $\mathrm{Mn}$ solubility during hydrothermal alteration of basalt and more felsic rock compositions is a complex and sensitive function of in situ $\mathrm{pH}$, in addition to temperature, pressure and fluid composition (Mottl et al., 1979; Hajash and Chandler, 1982; Rosenbauer and Bischoff, 1983; Seyfried and Janecky, 1985; Seyfried, 1987; Seewald and Seyfried, 1990). At PACMANUS, endmember Fe concentrations calculated from low $\mathrm{Mg}(<5 \mathrm{mmol} / \mathrm{kg})$ fluids range from 6.86 to $14.6 \mathrm{mmol} / \mathrm{kg}$, with corresponding endmember $\mathrm{Mn}$ concentrations of 3.01 to $4.72 \mathrm{mmol} / \mathrm{kg}$. These are among the highest $\mathrm{Fe}$ and $\mathrm{Mn}$ contents reported to date for either arc or back-arc basin hydrothermal fluids (Ishibashi and Urabe, 1995; Takai et al., 2008) and are most likely the result of the highly acidic nature of these fluids.

An evaluation of the $\mathrm{Fe}$ and $\mathrm{Mn}$ contents of Vienna Woods fluids in the context of experimental observations of their mobility from crystalline basalt as a function of temperature supports the notion that fluids there have experienced cooling. The association of extremely low endmember $\mathrm{Fe}$ contents with vent temperatures below $300^{\circ}$ (Table 2) is consistent with experimental evidence that dissolved Fe is rapidly diminished below this temperature in the absence of any seawater admixing (Seewald and Seyfried, 1990). In contrast to Fe, however, Mn has sluggish kinetics of re-precipitation upon cooling of hydrothermal fluids, and therefore tends to record much hotter temperatures of mobilization. Based upon the experimental study of Seewald and Seyfried (1990), Mn concentrations in Vienna Woods fluids (Table 2) are more consistent with 
temperatures up to $\sim 350^{\circ} \mathrm{C}$. Such high temperatures in the reaction zone would reconcile the observations of high $\mathrm{SiO}_{2}$ for the temperatures of venting that yield unreasonable apparent depths of quartz-fluid equilibrium (Fig. 10).

\subsection{Phase separation and $\mathrm{Cl}$ variability}

Vienna Woods and Pual Ridge fluids exhibit variable enrichments or depletions in endmember $\mathrm{Cl}$ relative to seawater (Table 2). While we demonstrate below that much of this variability is due to phase separation, prior magmaticor rock-derived $\mathrm{Cl}$ inputs must first be considered in the case of Pual Ridge fluids. $\mathrm{Cl}$ variations in MOR hydrothermal fluids beyond that permissible by rock hydration effects are typically attributed to phase separation (Von Damm, 1990, 1995; German and Von Damm, 2003; Foustoukos and Seyfried, 2007b) and rock-derived $\mathrm{Cl}$ is typically not considered a significant source to mid-ocean ridge vent fluids due to the low $\mathrm{Cl}$ content of MORB (Michael and Schilling, 1989; Michael and Cornell, 1998). Silicic crustal rocks in back-arc environments, however, have higher $\mathrm{Cl}$ contents (Wallace, 2005; Aiuppa et al., 2009) and dredged dacites from the vicinity of Pual Ridge contain up to $0.84 \mathrm{wt} \% \mathrm{Cl}$ (Sun et al., 2007). Quantitative leaching of such dacite at the water/rock ratios calculated previously (2-6) would only increase vent fluid chlorinity by $<120 \mathrm{mmol} / \mathrm{kg}$. Inputs of $\mathrm{Cl}$ from magmatic degassing could also influence chloride contents of Pual Ridge vent fluids, given the $\mathrm{Cl}$-rich nature of Pual Ridge magmas (Sun et al., 2007), and the chlorinity of magmatic fluids may be substantially higher or lower than seawater. While we demonstrate below that phase separation influences species abundances at Pual Ridge, based on the above considerations, hydrothermal fluids undergoing phase separation there may have initial chlorinities that differ from seawater.

Conclusive evidence for subcritical phase separation at seafloor pressures was found at the Fenway site where the maximum measured temperature of $358^{\circ} \mathrm{C}$ at $\mathrm{F} 3$ vent places this fluid on the 2-phase boundary for a fluid of seawater salinity (Fig. 3) at a seafloor pressure of 171 bar (Bischoff and Rosenbauer, 1985). The observed flashing and variability in dissolved major element and gas concentrations between multiple fluid samples collected at F3 (Table 1) are consistent with active boiling and partial segregation of a two-phase emulsion of immiscible vapor/ brine during venting at the seafloor (Bischoff and Pitzer, 1985; Hannington et al., 2001; Stoffers et al., 2006). Measured exit temperatures (Fig. 3) for all other vent fluids at PACMANUS and Vienna Woods lie well below the seawater 2-phase boundary at seafloor pressures. If phase separation at depth has contributed to $\mathrm{Cl}$ variability, these fluids must have undergone substantial cooling prior to venting at the seafloor. Previous phase separation at depth is supported by the rock record at Sites 1188 and 1189. Vanko et al. (2004) demonstrated that the temperatures and extreme salinity variations recorded by fluid inclusions at depth beneath Snowcap are consistent with subseafloor boiling at temperatures in excess of $\sim 350^{\circ} \mathrm{C}$, despite much cooler temperatures of venting.
At Vienna Woods, the low measured Mg concentrations preclude seawater mixing as a heat loss mechanism and extensive conductive cooling $\left(>100^{\circ} \mathrm{C}\right)$ is required to explain the low observed temperatures relative to the 2-phase boundary there (Fig. 3). As stated previously, Mn abundances in Vienna Woods fluids only suggest temperatures near $350{ }^{\circ} \mathrm{C}$ and so it is possible that the high $\mathrm{Cl}$ endmembers do not reflect active phase separation at depth in 2006, but rather entrainment/depletion of residual brines formed during previous phase separation events (Shanks and Seyfried, 1987; Von Damm and Bischoff, 1987; Von Damm, 1988; Butterfield and Massoth, 1994; Butterfield et al., 1997; Schoofs and Hansen, 2000; Von Damm et al., 2005). Brine entrainment would be consistent with the chronic venting of Cl-rich fluids at Vienna Woods since 1990 (Lisitsyn et al., 1993; Gamo et al., 1997; Douville et al., 1999a; Fourre et al., 2006) and the apparent absence of any $\mathrm{Cl}$-depleted conjugate fluids.

Measured temperatures below the 2-phase boundary, notwithstanding, systematic compositional variability between fluids within several PACMANUS vent areas strongly suggests that fluids other than F3 are also influenced by phase separation and segregation. Endmember concentrations of soluble alkali elements $\mathrm{K}, \mathrm{Li}, \mathrm{Rb}$, and $\mathrm{Cs}$ in areas with co-located vent fluids show strong linear correlations with endmember $\mathrm{Cl}$ that extrapolate toward the origin (Fig. 11). Because these elements are readily mobilized from the crust during high temperature fluid-rock interaction (Seyfried et al., 1984; Von Damm et al., 1985; Von Damm, 1995) and do not preferentially partition into the vapor phase (except under extreme conditions near halite saturation), alkali/Cl ratios are unaffected by phase separation (Berndt and Seyfried, 1990; Foustoukos and Seyfried, 2007b,c). This behavior implies phase separation and partial segregation of high and low salinity phases (Butterfield et al., 1994). Systematic variations in the endmember abundances of aqueous gases with $\mathrm{Cl}$ are also consistent with ongoing phase separation at PACMANUS. Endmember $\mathrm{CO}_{2}$ and $\mathrm{CH}_{4}$ concentrations at Fenway and Roman Ruins increase systematically with decreasing $\mathrm{Cl}$ (Fig. 5c and $5 \mathrm{~d}$ ), consistent with enhanced partitioning of volatile species into the lower salinity phases during phase separation. $\mathrm{H}_{2}$ and $\mathrm{H}_{2} \mathrm{~S}$ are much more variable (Fig. 5a and 5b) but these species behave non-conservatively during seawater admixing in the subsurface (see below). Processes in addition to phase separation, however, must be invoked to explain the extreme enrichments in dissolved $\mathrm{CO}_{2}$ at Satanic Mills and Snowcap (Fig. 5c). Enrichments of this magnitude in seafloor hydrothermal fluids are unlikely to be solely the result of partitioning of rock-derived $\mathrm{CO}_{2}$ into vapor phases (Butterfield et al., 1990, 1994, 2003; Seewald et al., 2003) and a combination of substantial magmatic $\mathrm{CO}_{2}$ inputs (discussed below), possibly with some secondary enhancement by phase separation, is the most plausible explanation.

\subsection{Magmatic fluid input at Pual Ridge}

Numerous investigations have examined the compositions of magmatic volatiles at PACMANUS recorded in erupted 

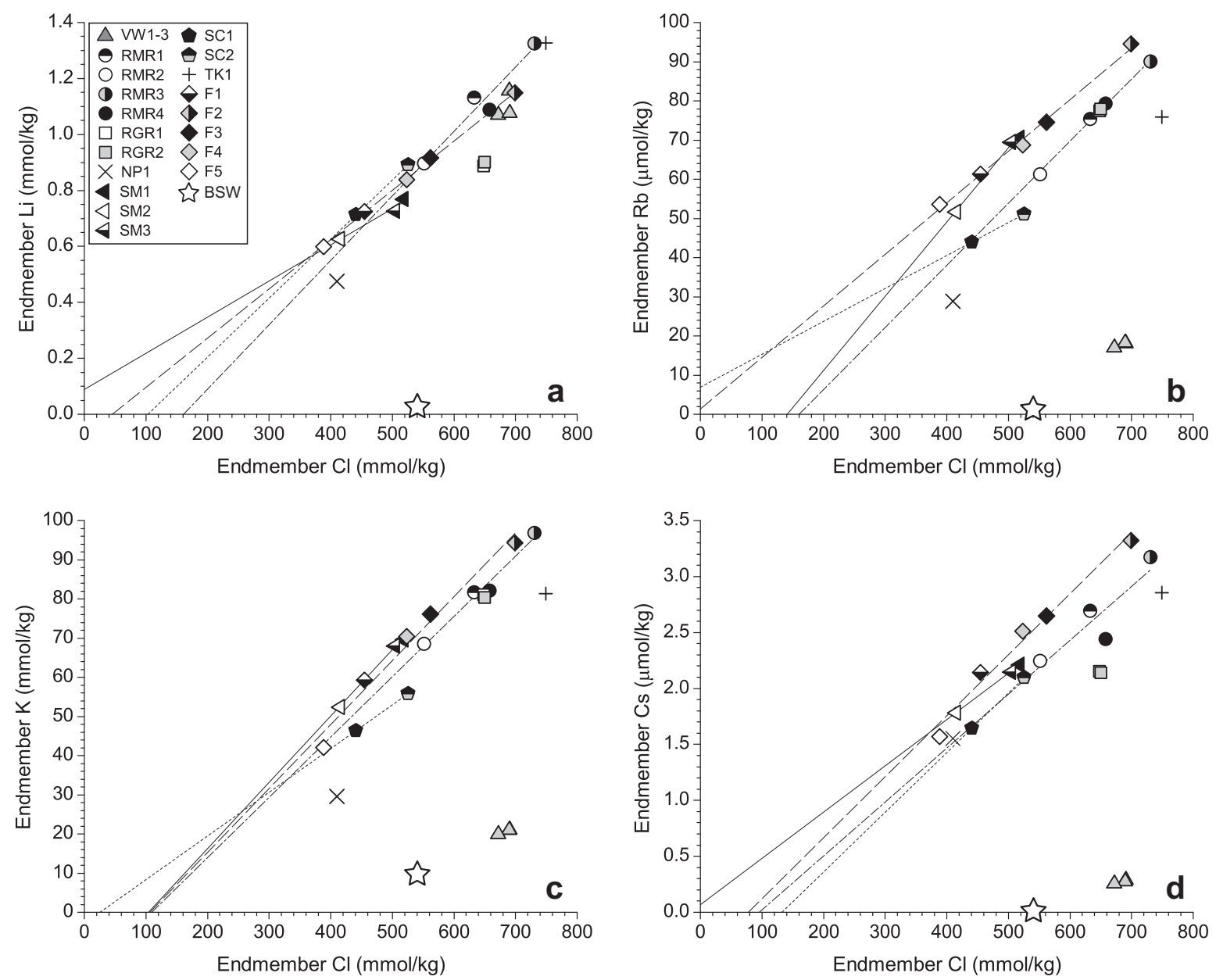

Fig. 11. Endmember $\mathrm{Li}(\mathrm{a}), \mathrm{Rb}(\mathrm{b}), \mathrm{K}$ (c) and $\mathrm{Cs}(\mathrm{d})$ concentrations vs. corresponding endmember $\mathrm{Cl}$ concentration for Vienna Woods, PACMANUS and NE Pual vent fluids. Solid (Satanic Mills), dashed (Fenway), dot-dashed (Roman Ruins) and dotted (Snowcap) lines represent unweighted linear least squared regressions of endmember fluid compositions within each respective vent area (limited to co-located vent fluids with largest degrees of intra-vent $\mathrm{Cl}$ variability). Co-located vent fluids (cf. Fig. 2) exhibit strong correlations with $\mathrm{Cl}$ which trend toward the origin, indicative of phase separation control and unmixing of high and low salinity fluid phases (Butterfield et al., 1994). BSW, bottom seawater.

lavas. Felsic lavas at Pual Ridge are highly vesicular (Binns and Scott, 1993; Marty et al., 2001; Paulick et al., 2004) and accompanying melt inclusions possess vapor bubbles containing $\mathrm{H}_{2} \mathrm{O}, \mathrm{CO}_{2}$ and sulfur precipitates (Yang and Scott, 1996, 2002; Kamenetsky et al., 2001, 2002). Yang and Scott (2005) suggested that fractional crystallization of magmas beneath Paul Ridge could sustain pre-eruptive degassing on timescales of several decades, comparable to the lifetimes of hydrothermal systems. Given that a magma body $2 \mathrm{~km}$ beneath the surface of Pual Ridge has been suggested (Lee, 2003; Binns et al., 2007; Sun et al., 2007) and apparent depths of quartz-fluid equilibrium for some Pual Ridge fluids discussed above are similar, it is reasonable to assume circulating hydrothermal fluids there may reach sufficient depths to entrain volatiles exsolved from degassing silicic magma (Fig. 8).

\subsubsection{Isotopic evidence for magmatic $\mathrm{H}_{2} \mathrm{O}$}

Addition of magmatic water to Pual Ridge vent fluids is evident in the stark contrast in $\mathrm{H}_{2} \mathrm{O}$ isotopic compositions there compared to fluids at Vienna Woods (Fig. 12). The stable isotopic composition of vent fluid $\mathrm{H}_{2} \mathrm{O}$ can record the integrated effects of three fundamental processes water/rock (and/or sediment) interaction, phase separation and any contributions from extraneous magmatic waters. Hydration reactions between circulating hydrothermal fluids and igneous crust at high temperatures invariably yield a trend of increasing $\delta^{18} \mathrm{O}_{\mathrm{H}_{2} \mathrm{O}}$ and $\delta \mathrm{D}_{\mathrm{H}_{2} \mathrm{O}}$ values (relative to unmodified seawater) with decreasing water/rock ratios (Bowers and Taylor, 1985; Bowers, 1989; Shanks et al., 1995; Shanks, 2001). $\delta^{18} \mathrm{O}_{\mathrm{H}_{2} \mathrm{O}}$ and $\delta \mathrm{D}_{\mathrm{H}_{2} \mathrm{O}}$ values from Vienna Woods are therefore generally consistent with water/ rock reaction as the dominant control of the isotopic composition of vent waters there. While the more positive endmember $\delta^{18} \mathrm{O}_{\mathrm{H}_{2} \mathrm{O}}$ values of PACMANUS fluids are consistent with water/rock reaction at higher temperatures and/or lower water/rock ratios than Vienna Woods, alternate mechanisms must be invoked to explain the ubiquitous negative endmember $\delta \mathrm{D}_{\mathrm{H}_{2} \mathrm{O}}$ values there (Fig. 12). 


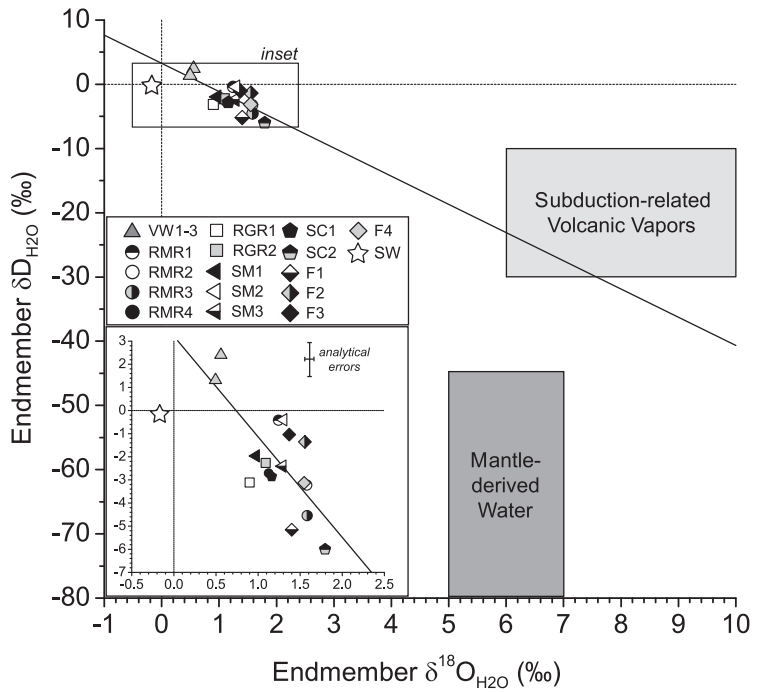

Fig. 12. Endmember $\delta \mathrm{D}_{\mathrm{H}_{2} \mathrm{O}}$ and $\delta^{18} \mathrm{O}_{\mathrm{H}_{2} \mathrm{O}}$ values from Vienna Woods and PACMANUS vent fields, with axes expanded to show postulated compositions of mantle-derived water (Taylor, 1979b; Ohmoto, 1986) and subduction-related volcanic vapors (Giggenbach, 1992; Hedenquist and Lowenstern, 1994). For clarity, the inset shows the data at a larger scale and 1s analytical errors. The isotopic composition of Pacific bottom seawater (SW) is shown by a star (Craig and Gordon, 1965; Redfield and Friedman, 1965). Low temperature fluids with near-SW Mg concentrations (F5, TK1 and NP1) are not plotted due to the large uncertainty associated with extrapolation of $\delta \mathrm{D}_{\mathrm{H}_{2} \mathrm{O}}$ and $\delta^{18} \mathrm{O}_{\mathrm{H}_{2} \mathrm{O}}$ values to zero $\mathrm{Mg}$. The solid black line represents a least squares regression of all PACMANUS and Vienna Woods isotopic compositions (excluding SW). This extrapolated trend strongly suggests PACMANUS compositions reflect mixing between subduction-related volcanic vapor compositions and an evolved SW-derived hydrothermal fluid (see text)

Although phase separation is occurring at Pual Ridge (as discussed previously), and experimental studies have shown that this process can affect the hydrogen and oxygen isotopic composition of vent waters (Horita et al., 1995; Berndt et al., 1996; Shmulovich et al., 1999; Foustoukos and Seyfried, 2007b), it cannot account for the hydrogen isotope composition of vent fluids there. Under most openor closed-system scenarios for phase separation, vapor phases are slightly enriched in D relative to the heavily D-depleted brine phases, while the reverse is true for oxygen isotope partitioning (Berndt et al., 1996; Foustoukos and Seyfried, 2007b). Examination of the PACMANUS fluids reveals no systematic variations in $\delta \mathrm{D}_{\mathrm{H}_{2} \mathrm{O}}$ or $\delta^{18} \mathrm{O}_{\mathrm{H}_{2} \mathrm{O}}$ with endmember $\mathrm{Cl}$ (Table 2). Furthermore, low chlorinity fluids have consistently negative $\delta \mathrm{D}_{\mathrm{H}_{2} \mathrm{O}}$ and positive $\delta^{18} \mathrm{O}_{\mathrm{H}_{2} \mathrm{O}}$, opposite to the trend expected for phase separation. While Berndt et al. (1996) propose that generation of a vapor phase with highly negative $\delta \mathrm{D}_{\mathrm{H}_{2} \mathrm{O}}$ and positive $\delta^{18} \mathrm{O}_{\mathrm{H}_{2} \mathrm{O}}$ values is conceivable under a scenario of combined water/rock reaction and open-system phase separation during isobaric heating (i.e. by subsurface dike emplacement), it requires segregation of a heavily distilled vapor (Foustoukos and Seyfried, 2007b). No such vapor-like fluids were observed at PACMANUS. Negative $\delta \mathrm{D}_{\mathrm{H}_{2} \mathrm{O}}$ values and positive $\delta^{18} \mathrm{O}_{\mathrm{H}_{2} \mathrm{O}}$ values can also be produced by extensive reaction of hydrothermal fluids with sedimentary overburden (Shanks et al., 1995; Von Damm et al., 2005). However, given the negligible sediment cover on the crest of Pual Ridge (Binns et al., 2007) and the lack of a thermogenic $\delta^{13} \mathrm{C}_{\mathrm{CH}_{4}}$ signature (Table 2, Welhan, 1988; Cruse and Seewald, 2006), there is no evidence to suggest that fluids there have interacted with sediments. Direct input of isotopically distinct magmatic water to seawater-derived hydrothermal fluids is therefore most plausible explanation the array of negative $\delta \mathrm{D}_{\mathrm{H}_{2} \mathrm{O}}$ and positive $\delta^{18} \mathrm{O}_{\mathrm{H}_{2} \mathrm{O}}$ values at Pual Ridge.

The isotopic signature of 'juvenile' or mantle-derived magmatic water is estimated to have a narrow range of $\delta \mathrm{D}_{\mathrm{H}_{2} \mathrm{O}}(-65 \pm 20 \%)$ and $\delta^{18} \mathrm{O}_{\mathrm{H}_{2} \mathrm{O}}(+6 \pm 1 \%$ ), (Taylor, 1979b; Ohmoto, 1986). In contrast, waters degassed from silicic arc magmas (subduction-related volcanic vapors, SRVV) may have much higher $\delta \mathrm{D}_{\mathrm{H}_{2} \mathrm{O}}(-10 \%$ to $-30 \%)$ and $\delta^{18} \mathrm{O}_{\mathrm{H}_{2} \mathrm{O}}(+6 \%$ to $+10 \%$ ) values (Giggenbach, 1992; Hedenquist and Lowenstern, 1994). Degassing-related fractionation and slab-derived seawater inputs can both increase the $\delta \mathrm{D}_{\mathrm{H}_{2} \mathrm{O}}$ value of magmatic waters at convergent margins (Taylor, 1986, 1997; Giggenbach, 1992; Pineau et al., 1998; Shaw et al., 2008). While it is impossible to accurately constrain the isotopic composition of magmatic water added, the array of PACMANUS isotopic compositions trends toward a D-depleted and highly ${ }^{18} \mathrm{O}$-enriched component similar to SRVV compositions (Fig. 12). The fluids do not lie within the trend expected for simple mixing of hydrothermal fluids with mantle-derived waters having $\delta \mathrm{D}_{\mathrm{H}_{2} \mathrm{O}}$ values of $-40 \%$ to $-80 \%$ (Fig. 12), as suggested for fluids from the nearby DESMOS hydrothermal system (Gamo et al., 1997). Although the isotopic compositions of PACMANUS vent waters could reflect the addition of SRVV compositions directly to seawater, it is hard to envision a scenario where seawater could reach high temperature environments in the vicinity of a degassing magma chamber without extensive isotopic modification by water/rock reaction. The most likely scenario is that SRVV-like compositions are mixing with seawater-derived hydrothermal fluids that have experienced high temperature fluid-rock interactions which increased $\delta \mathrm{D}_{\mathrm{H}_{2} \mathrm{O}}$ and $\delta^{18} \mathrm{O}_{\mathrm{H}_{2} \mathrm{O}}$ values (resembling the evolved compositions at Vienna Woods, Figs. 8 and 12).

A crude estimate of the minimum quantity of magmatic $\mathrm{H}_{2} \mathrm{O}$ added to circulating fluids can be constrained by simple hydrogen isotope mass balance. For this calculation we assume that the effects of phase separation on $\delta \mathrm{D}_{\mathrm{H}_{2} \mathrm{O}}$ are negligible, magmatic $\mathrm{H}_{2} \mathrm{O}$ at all PACMANUS areas has a uniform $\delta \mathrm{D}_{\mathrm{H}_{2} \mathrm{O}}$ value at the lower limit of SRVV compositions $(-30 \%$, Giggenbach, 1992; Hedenquist and Lowenstern, 1994) and the circulating fluids into which magmatic waters are entrained have $\delta \mathrm{D}_{\mathrm{H}_{2} \mathrm{O}}$ values similar to Vienna Woods fluids $(+2.4 \%$ ) due to prior water/rock reaction. With these assumptions in mind, a magmatic $\mathrm{H}_{2} \mathrm{O}$ fraction of $\sim 9 \mathrm{wt} \%$ is required to produce the composition observed in Roman Ruins fluid RMR1 (the highest $\delta \mathrm{D}_{\mathrm{H}_{2} \mathrm{O}}$ value in Fig. 12). Fluid at the Snowcap SC2 vent would require a magmatic $\mathrm{H}_{2} \mathrm{O}$ fraction of $\sim 25 \mathrm{wt} \%$, with the majority of fluids within these two extremes. While these estimates are speculative and highly variable, they 
do suggest substantial quantities of magmatic water are entrained by circulating hydrothermal fluids.

The isotopic compositions of PACMANUS fluids presented here also have implications for previous attempts to estimate subsurface alteration temperatures from drillcore clay minerals recovered at Sites 1188 and 1189. Lackschewitz et al. (2004) assumed that hydrothermal fluids at depth have near-seawater $\delta^{18} \mathrm{O}_{\mathrm{H}_{2} \mathrm{O}}$ values and calculated temperatures of clay mineral precipitation in the subsurface. This assumption is now shown to be unreasonable, given that both magmatic water input and water/rock interaction have substantially increased $\delta^{18} \mathrm{O}_{\mathrm{H}_{2} \mathrm{O}}$ values at PACMANUS.

\subsubsection{Magmatic $\mathrm{CO}_{2}, \mathrm{~F}$, and $\mathrm{Cl}$}

Elevated abundances of aqueous $\mathrm{CO}_{2}$ in PACMANUS vent fluids are also consistent with a direct contribution of magmatic volatiles because $\mathrm{CO}_{2}$ is invariably released from silicic magmas during cooling and crystallization (Carroll and Webster, 1994; Yang and Scott, 2006). Although some of the $\mathrm{CO}_{2}$ observed in PACMANUS fluids may be derived from rock leaching, unaltered subseafloor dacites recovered by ODP drilling at Snowcap, Roman Ruins and Satanic Mills contain less than 500 ppm residual $\mathrm{CO}_{2}$ (Paulick et al., 2004). Assuming quantitative mobilization, this limits the total amount of $\mathrm{CO}_{2}$ that can be derived by substrate leaching to $<6 \mathrm{mmol} / \mathrm{kg}$ for the range of water/ rock ratios (2-6) calculated using alkali abundances. Concentrations of aqueous $\mathrm{CO}_{2}$ in basalt-hosted mid-ocean ridge vent fluids that approach values observed at PACMANUS have also been attributed to active magmatic degassing (Butterfield et al., 2003; Lilley et al., 2003; Seewald et al., 2003). While primary $\mathrm{CO}_{2}$ contents of parental magmas at PACMANUS are poorly constrained (Marty et al., 2001), weight percent additions of magmatic $\mathrm{H}_{2} \mathrm{O}$ (estimated above) indicate that $\mathrm{CO}_{2}$ is far less abundant than $\mathrm{H}_{2} \mathrm{O}$ in the magmatic fluids being added. The exsolution of a water-dominated magmatic fluid suggests a relatively shallow (crustal) magma chamber (Yang and Scott, 2006), consistent with the speculation of a fractionating silicic magma body beneath Pual Ridge (Lee, 2003; Yang and Scott, 2005; Binns et al., 2007; Sun et al., 2007).

Examination of the carbon isotopic composition of vent fluid $\mathrm{CO}_{2}$ at PACMANUS $(-4.1 \%$ to $-2.3 \%$ ) reveals a more ${ }^{13} \mathrm{C}$ enriched $\mathrm{CO}_{2}$ source relative to Vienna Woods fluids $(-5.2 \%$ to $-5.7 \%$ o $)$, which likely reflects the closer proximity of Pual Ridge to the New Britain Arc $(80 \mathrm{~km}$ vs. $220 \mathrm{~km}$ ) and a larger contribution of more ${ }^{13} \mathrm{C}$-enriched slab-derived carbon. $\delta^{13} \mathrm{C}_{\mathrm{CO}_{2}}$ values in fluids from unsedimented hydrothermal systems measured to date range from $-3.15 \%$ to $-13.0 \%$ (Charlou et al., 1996, 2002; McCollom and Seewald, 2007) but the majority of typical basalthosted fluids range from $-4 \%$ to $-9 \%$ (Kelley et al., 2004), reflecting the composition of primitive mantle $\mathrm{CO}_{2}$ $(-5 \%$ to $-8 \%$, Pineau et al., 1976; Taylor, 1986; Cartigny et al., 2001; Coltice et al., 2004). Based on the few studies conducted to date, dissolved $\mathrm{CO}_{2}$ in back-arc hydrothermal fluids are typically more ${ }^{13} \mathrm{C}$-enriched, with $\delta^{13} \mathrm{C}_{\mathrm{CO}_{2}}$ values ranging from $+0.4 \%$ at Mariner (Lau Basin) to $-6.2 \%$ at White Lady (N. Fiji Basin), (Ishibashi et al., 1994; Takai et al., 2008). Vent fluid $\delta^{13} \mathrm{C}_{\mathrm{CO}_{2}}$ values higher than mantle carbon values can arise from two potential processes -

${ }^{13} \mathrm{C}$ enrichment in the source magma due to slab-derived carbonate inputs and/or degassing-related fractionation effects. In the case of the latter, the $\mathrm{CO}_{2}$ initially degassed from basaltic magmas can be enriched in ${ }^{13} \mathrm{C}$ by several per mil (i.e. $2.2-4.3 \%$ at $>1100{ }^{\circ} \mathrm{C}$ ) relative to the undegassed bulk $\mathrm{CO}_{2}$ reservoir (Javoy et al., 1978; Mattey, 1991). Such enrichments are only associated with the earliest stages of $\mathrm{CO}_{2}$ exsolution (Tsunogai et al., 1994), however, and the extremely low $\mathrm{CO}_{2}$ contents (Marty et al., 2001) and low $\delta^{13} \mathrm{C}_{\mathrm{CO}_{2}}$ values observed in EMVZ lavas (down to $-33.2 \%$, Shaw et al., 2004) suggest more extensive degassing of crustal magmas there. The ${ }^{13} \mathrm{C}$-enriched nature of aqueous $\mathrm{CO}_{2}$ at PACMANUS therefore may reflect the greater influence of slab-derived carbon on the magma source in this region of the basin. Subducted oceanic crust can contain sedimentary organic carbon/carbonate and carbonates formed during low temperature alteration of basaltic rocks (Alt and Teagle, 1999; Coltice et al., 2004), giving a bulk slab $\delta^{13} \mathrm{C}$ value of approximately $-1 \%$ (Coltice et al., 2004). Numerous geochemical proxies (e.g. higher $\mathrm{Ba} / \mathrm{Nb}$ and $\mathrm{Cl} / \mathrm{Nb}$ ratios in dredged lavas) indicate greater subduction-related inputs to magmas in the EMVZ (and Pual Ridge) relative to the MSC (Kamenetsky et al., 2001; Sinton et al., 2003; Sun et al., 2004; Pearce and Stern, 2006; Park et al., 2010) and inputs of slab-derived carbon have been suggested (Shaw et al., 2004). Trends of increasing $\delta^{13} \mathrm{C}_{\mathrm{CO}_{2}}$ with arc proximity have been observed in other back-arc vent fluids, such as the Lau Basin (Proskurowski et al., 2007) and the Okinawa Trough/Mariana Arc (cf. Sakai et al., 1990a; Lupton et al., 2006).

High concentrations of magmatic $\mathrm{CO}_{2}$ in PACMANUS vent fluids are also accompanied by elevated $\mathrm{F}$ abundances (Fig. 6), which may reflect inputs of $F$ to convecting hydrothermal fluids from magmatic degassing. Fluoride species are enriched in felsic magmas (Carroll and Webster, 1994) and are common constituents of exsolved magmatic gases in arc-type environments (Yang and Scott, 2006; Aiuppa et al., 2009). Magmatic F has been implicated in influencing REE distribution patterns in vent fluids and anhydrites from Manus Basin hydrothermal sites (Bach et al., 2003; Craddock et al., 2010). The F enrichments in Pual Ridge vent fluids are in stark contrast to Vienna Woods (Fig. 6) and MOR hydrothermal systems, where F is depleted relative to seawater (Edmond et al., 1979a; Maris et al., 1984; Von Damm et al., 1985; Seyfried and Ding, 1995a; German and Von Damm, 2003). While a magmatic origin is certainly likely given the other indications of volatile input, we cannot, however, completely discount rock-derived sources of $F$. The behavior of $F$ in seafloor hydrothermal systems is poorly understood (Seyfried and Ding, 1995a) and there is some experimental evidence to suggest both mineralogical sources and sinks of $\mathrm{F}$ are possible during hydrothermal alteration of silicic rock compositions (Galluccio et al., 2009). Rock leaching has also been proposed as a source of $\mathrm{F}$ to some felsic-hosted terrestrial geothermal systems (Arnorsson et al., 1978). The F contents of unaltered Pual Ridge dacites (360-530 ppm, Paulick et al., 2004) are not substantially different from MSC basalts 
( 200 ppm, Sinton et al., 2003) and typical MORB ( $\sim 500 \mathrm{ppm}$, Michael and Schilling, 1989) and incomplete leaching at calculated $\mathrm{w} / \mathrm{r}$ ratios $(\sim 0.5$ for Vienna Woods, 2-6 for Pual Ridge) could yield aqueous F concentrations several times that of seawater in either setting. Therefore, while the correlation of $\mathrm{F}$ with $\mathrm{CO}_{2}$ (Fig. 6) is suggestive of a magmatic origin, further constraints are needed on the mobility of $\mathrm{F}$ in hydrothermal systems before the excess abundances relative to typical MOR hydrothermal fluids can be attributed solely to magmatic degassing.

In addition to $\mathrm{CO}_{2}$ and $\mathrm{F}$, magmatic fluids at Pual Ridge could also contain varying amounts of $\mathrm{Cl}$ but we cannot constrain such inputs, however, owing to the high quantities of seawater $\mathrm{Cl}$ and variability arising from phase separation. Exsolved magmatic fluids may be characterized by chlorinities comparable to or much lower than seawater. At supercritical magmatic temperatures and shallow crustal pressures, Cl-bearing magmatic fluids can separate into low $\mathrm{Cl}$ vapor phases containing the bulk of $\mathrm{H}_{2} \mathrm{O}$ mass and small quantities of a Cl-rich brine condensate (Cline and Bodnar, 1991; Shinohara, 1994; Kelley and Früh-Green, 2000; Lowenstern, 2000; Webster, 2004). Additional lines of evidence, such as $\mathrm{Br} / \mathrm{Cl}$ ratios, would not be useful in identifying the addition of magmatic fluids because molar $\mathrm{Br} / \mathrm{Cl}$ ratios in high temperature $\left(>700^{\circ} \mathrm{C}\right)$ fumaroles from western Pacific arc volcanoes (0.6-1.4, Goff and McMurtry, 2000; Snyder et al., 2002) approach those of the seawater value of 1.5. Most Pual Ridge fluids do not deviate from the latter ratio (Table 3 ).

\subsubsection{Magmatic $\mathrm{SO}_{2}$ input and disproportionation}

There is some indirect evidence to suggest that magmatic fluids entrained by Pual Ridge vent fluids are accompanied by $\mathrm{S}$ species that generate substantial acidity. We conclude, however, that much of the primary signature of magmatic $S$ has likely been overprinted by secondary processes subsequent to magmatic degassing and prior to seafloor venting (Fig. 8). Exsolved $\mathrm{CO}_{2}$ and $\mathrm{H}_{2} \mathrm{O}$-rich vapor bubbles in melt inclusions from Pual Ridge contain a host of sulfate- and sulfide-bearing minerals, indicating that sulfurous species have partitioned from magmas into exsolved aqueous fluids there (Kamenetsky et al., 2001, 2002; Yang and Scott, 2006). In contrast to basaltic magmas, where it exists mostly as sulfide, total $\mathrm{S}$ in more oxidizing (higher $f_{\mathrm{O}_{2}}$ ) calc-alkaline magmas is predominantly in the forms $\mathrm{SO}_{2}$ and $\mathrm{SO}_{4}$ (Burnham, 1979; Carroll and Rutherford, 1988; Nilsson and Peach, 1993; Carroll and Webster, 1994). $\mathrm{SO}_{2}$ strongly partitions into exsolved aqueous fluids during magmatic degassing (Burnham, 1979; Scaillet and Pichavant, 2003 ) and, upon cooling below $\sim 400^{\circ} \mathrm{C}$, can undergo either of the following disproportionation reactions (Iwasaki and Ozawa, 1960; Holland, 1965; Drummond, 1981; Kusakabe et al., 2000):

$4 \mathrm{SO}_{2}+4 \mathrm{H}_{2} \mathrm{O} \rightarrow \mathrm{H}_{2} \mathrm{~S}+3 \mathrm{H}_{2} \mathrm{SO}_{4}$

$3 \mathrm{SO}_{2}+2 \mathrm{H}_{2} \mathrm{O} \rightarrow \mathrm{S}^{0}+2 \mathrm{H}_{2} \mathrm{SO}_{4}$

where $\mathrm{S}^{0}$ is zero-valent sulfur. According to Kusakabe et al. (2000), reaction (3) is more favored under higher temperatures and lower $\mathrm{SO}_{2}$ contents than reaction (4). Both reactions are rapid, produce sulfuric acid $\left(\mathrm{H}_{2} \mathrm{SO}_{4}\right.$, which

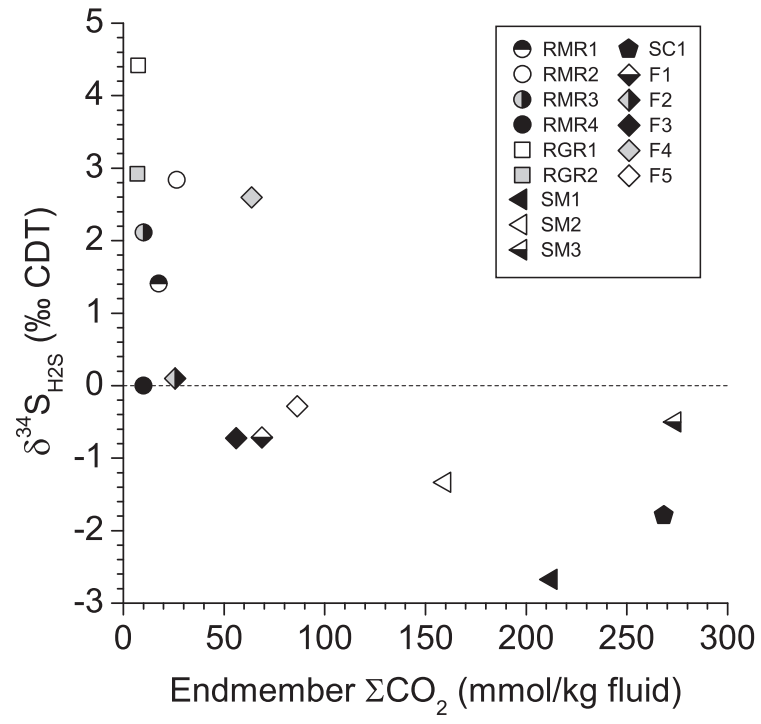

Fig. 13. $\delta^{34} \mathrm{~S}$ values for dissolved $\mathrm{H}_{2} \mathrm{~S}\left(\delta^{34} \mathrm{~S}_{\mathrm{H}_{2} \mathrm{~S}}\right)$ vs. endmember $\Sigma \mathrm{CO}_{2}$ concentrations. The range of $\delta^{34} \mathrm{~S}_{\mathrm{H}_{2} \mathrm{~S}}$ values for unsedimented hydrothermal systems in MOR settings is $+1.4 \%$ o to $+8.6 \%$ (Shanks, 2001). Values from Pual Ridge fluids below this range are associated with higher $\mathrm{CO}_{2}$ concentrations of magmatic origin.

generates acidity upon dissociation to $\mathrm{HSO}_{4}{ }^{-}$and $\mathrm{H}^{+}$) and are associated with significant sulfur isotope fractionations between reactant $\mathrm{SO}_{2}$ and the oxidized and reduced $\mathrm{S}$ products. $\mathrm{H}_{2} \mathrm{SO}_{4}$ is typically enriched in ${ }^{34} \mathrm{~S}$, while $\mathrm{H}_{2} \mathrm{~S}$ and $\mathrm{S}^{0}$ are depleted in ${ }^{34} \mathrm{~S}$ relative to precursor $\mathrm{SO}_{2}(\mathrm{Ohmoto}$ and Rye, 1979; Ohmoto and Goldhaber, 1997; Kusakabe et al., 2000). The $\mathrm{SO}_{4}$ produced invariably has a $\delta^{34} \mathrm{~S}_{\mathrm{SO}_{4}}$ value that is lower than seawater $(+20.99 \%$, Rees et al., 1978), while negative $\delta^{34} \mathrm{~S}_{\mathrm{H}_{2} \mathrm{~S}}$ values would be expected for $\mathrm{H}_{2} \mathrm{~S}$ assuming an initial magma $\delta^{34} \mathrm{~S}$ near $0 \%$ (Ohmoto and Goldhaber, 1997).

Negative $\delta^{34} \mathrm{~S}_{\mathrm{H}_{2} \mathrm{~S}}$ values are observed in fluids from some areas of PACMANUS (Satanic Mills and Snowcap) and are associated with extremely high levels of magmatic $\mathrm{CO}_{2}$ (Fig. 13). $\delta^{34} \mathrm{~S}_{\mathrm{H}_{2} \mathrm{~S}}$ values from unsedimented MOR hydrothermal systems range from $+1.4 \%$ to $+8.6 \%$, reflecting a mixture of both reduced seawater $\mathrm{SO}_{4}$ and basaltic $\mathrm{S}$ (Shanks, 2001, and references therein). The most negative $\delta^{34} \mathrm{~S}_{\mathrm{H}_{2} \mathrm{~S}}$ values (as low as $-5.7 \%$ ) measured to date were from fluids at the DESMOS Caldera site to the east of Pual Ridge in 1995 and were attributed to magmatic $\mathrm{SO}_{2}$ disproportionation (Gamo et al., 1997). As stated previously, there is no evidence to suggest fluids at Pual Ridge have interacted with sediments and the most plausible explanation for the above trend is that some of the $\mathrm{H}_{2} \mathrm{~S}$ in Satanic Mills and Snowcap fluids is derived either directly from magmatic $\mathrm{SO}_{2}$ disproportionation, or possibly by reduction of magmatic $\mathrm{SO}_{4}$ with low $\delta^{34} \mathrm{~S}_{\mathrm{SO}_{4}}$ values.

In contrast to $\delta^{34} \mathrm{~S}_{\mathrm{H}_{2} \mathrm{~S}}, \delta^{34} \mathrm{~S}_{\mathrm{SO}_{4}}$ values for all Pual Ridge fluids do not deviate substantially from that of seawaterderived $\mathrm{SO}_{4}$ (Table 1) and are therefore inconsistent with a magmatic origin for dissolved $\mathrm{SO}_{4}$. The general absence of anomalous $\delta^{34} \mathrm{~S}_{\mathrm{SO}_{4}}$ compositions that might be expected from addition and disproportionation of magmatic $\mathrm{SO}_{2}$, 
however, is not surprising considering the strong retrograde solubility of anhydrite as a function of temperature (Bischoff and Dickson, 1975; Bischoff and Seyfried, 1978; Mottl and Holland, 1978). If it is assumed that magmatic fluids are entrained (and therefore diluted) by circulating high temperature fluids at considerable depth in the hydrothermal reservoir (near the high temperature reaction zone, Fig. 8) any $\mathrm{SO}_{4}$ added could be quantitatively removed as anhydrite if a continuous supply of $\mathrm{Ca}$ is available from fluid-mineral equilibrium reactions. The widespread occurrence of anhydrite in the subsurface (Binns et al., 2007) and the extensive removal of seawater sulfate evident in presentday PACMANUS fluids (Fig. 4) is an indication of the ability the former mechanism to overwhelm a magmatic source of $\mathrm{SO}_{4}$.

These observations are consistent with evidence arising from ODP Leg 193 to suggest variable magmatic $\mathrm{SO}_{2}$ input, disproportionation and removal to anhydrite has previously occurred at depth beneath PACMANUS. Two independent investigations demonstrated $\delta^{34} \mathrm{~S}_{\mathrm{SO}_{4}}$ values as low as $+16.6 \%$ (Craddock and Bach, 2010) and $+18.1 \%$ (Roberts et al., 2003) in anhydrite deposited beneath Snowcap, with trends of decreasing $\delta^{34} \mathrm{~S}_{\mathrm{SO}_{4}}$ with increasing depth below the seafloor. These trends were interpreted to be the result of precipitation from fluids with variable mixtures of both seawater- and magmatic $\mathrm{SO}_{2}$-derived $\mathrm{SO}_{4}$, with the proportion of the latter increasing with depth beneath the Snowcap dome. Several inactive outcrops of bleached volcaniclastic material cemented with native sulfur $\left(\mathrm{S}^{0}\right)$ were also found in the vicinity of Snowcap (Tivey et al., 2006), suggesting that magmatic acid-sulfate fluids may have reached the seafloor in the past.

The extremely high Fe contents of many PACMANUS fluids suggests that magmatic-derived acidity has lead to extensive dissolution of $\mathrm{Fe}$ from silicate minerals in the subsurface, which could have consumed $\mathrm{H}^{+}$and raised in situ $\mathrm{pH}$. Measured $\mathrm{pH}$ values are still lower than experimental observations of equilibrium buffering by the andesite/dacite mineral assemblage (Hajash and Chandler, 1982; Shiraki et al., 1987), suggesting that titration of magmatic acidity may be incomplete. One possible explanation is that rocks in the upflow zones at Pual Ridge may be completely altered and characterized by mineral assemblages that are stable at low $\mathrm{pH}$, as suggested by ODP Leg 193 observations beneath Snowcap (Binns et al., 2007). The latter would likely be incapable of buffering $\mathrm{pH}$ values to the same extent as fresh andesite/dacite mineral assemblages. While dissolved alkali abundances and ratios (Fig. 9) clearly indicate interactions with fresh host rock at Pual Ridge, this may reflect water-rock interactions prior to magmatic fluid input (Fig. 8).

\subsubsection{Spatial variability of magmatic fluid inputs}

Our data are remarkably consistent with ODP Leg 193 observations which demonstrated apparent spatial variability of magmatic inputs within the PACMANUS vent field. Observations of anomalous subsurface anhydrite $\delta^{34} \mathrm{~S}_{\mathrm{SO}_{4}}$ values, rare-earth element patterns and 'acid-sulfate' (quartz-illite-pyrophyllite-anhydrite) alteration assemblages were limited to the Site 1188 (beneath the Snowcap
Dome) and were lacking at Site 1189 (Roman Ruins), (Bach et al., 2003; Roberts et al., 2003; Binns et al., 2007; Craddock and Bach, 2010). The data collected in 2006 demonstrates that vent fluids from Snowcap and the nearby Satanic Mills area clearly contain the strongest signatures of $\mathrm{H}_{2} \mathrm{O}, \mathrm{CO}_{2}, \mathrm{H}_{2} \mathrm{~S}$, and possibly $\mathrm{F}$ of magmatic origin. What is perplexing, however, is that while there is a notable absence of extremely high concentrations of $\mathrm{CO}_{2}$ and anomalous $\delta^{34} \mathrm{~S}_{\mathrm{H}_{2} \mathrm{~S}}$ values in Roman and Roger's Ruins vent fluids, $\delta \mathrm{D}_{\mathrm{H}_{2} \mathrm{O}}$ and $\mathrm{pH}$ values there resemble those of low Mg fluids from Satanic Mills and are consistent with magmatic inputs. Given the poor constraints on compositional variability of magmatic fluids in back-arc hydrothermal systems and the high degrees of dilution by circulating hydrothermal fluids, it may be that magmatic fluid compositions at Roman and Roger's Ruins contain lower amounts of $\mathrm{CO}_{2}$ and $\mathrm{SO}_{2}$. The resulting $\mathrm{SO}_{2}$-derived $\delta^{34} \mathrm{~S}_{\mathrm{H}_{2} \mathrm{~S}}$ anomalies may be relatively small and suffer from extensive overprinting. While we acknowledge it is also possible that Roman and Roger's Ruins fluids may not be entraining magmatic fluids at depth, this would require some unknown alteration assemblage capable of buffering both $\mathrm{pH}$ and $\delta \mathrm{D}_{\mathrm{H}_{2} \mathrm{O}}$ values to the same extent as the as Snowcap, Satanic Mills and Fenway fluids.

\subsection{Subsurface seawater entrainment}

The large number of sample sets taken from Pual Ridge vent fluids with consistently high measured $\mathrm{Mg}$ concentrations (Table 1) strongly suggests that fluids there have mixed with seawater to varying extents prior to exiting at the seafloor. Mixing of seawater and hydrothermal fluids prior to venting has been recognized ever since hydrothermal activity was first discovered in 1977 at the Galápagos Spreading Center (Corliss et al., 1979; Edmond et al., 1979a,b, 1995; Butterfield and Massoth, 1994; Tivey et al., 1995; Gamo et al., 1996c; Von Damm et al., 1998; Gallant and Von Damm, 2006). The hypothesis that extensive subsurface mixing provides much of the $\mathrm{Mg}$ in Pual Ridge fluids can be tested by examining the relationship between $\mathrm{Mg}$ abundance and temperature for co-located vents. Isenthalpic mixing lines depicting temperature and $\mathrm{Mg}$ during addition of $3{ }^{\circ} \mathrm{C}$ seawater to the hottest endmember fluids at Roman Ruins and Fenway are shown in Fig. 14. If other fluids in each vent area represent conservative mixtures of the hottest co-located fluid and cold seawater they should fall on these mixing lines. Only fluids where at least two samples with consistent vent temperature measurements and $\mathrm{Mg}$ concentrations are plotted to prevent ambiguity introduced by seawater entrainment during sampling. Examination of Fig. 14 reveals that the clustered vents RMR4, RMR1 and RMR2 (Fig. 2b) display a conservative trend. At Fenway, the diffuse F5 vent appears to be a conservative mixture of seawater and the nearby F3 black smoker vent fluid. Vents F2 and F4 fall below predicted temperatures, suggesting that in some cases conductive cooling may be occurring in addition to mixing. Temperature loss due to the former could explain the anomalously low apparent pressure of quartz-fluid equilibrium for F4 vent, and possibly other fluids also (Fig. 10). The agreement 


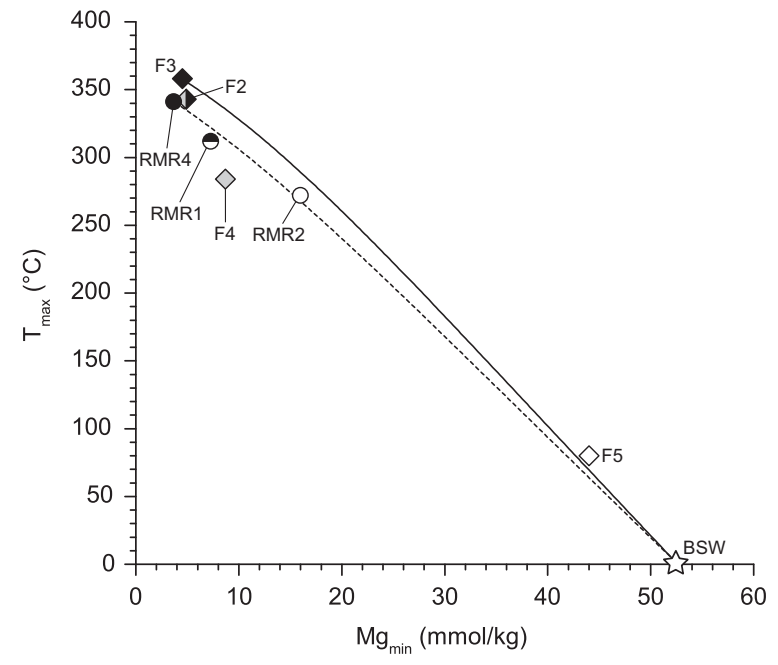

Fig. 14. Lowest $\mathrm{Mg}$ concentration $\left(\mathrm{Mg}_{\mathrm{min}}\right)$ at a given vent fluid vs. its vent temperature $\left(T_{\max }\right)$ for co-located vent fluids at Roman Ruins and Fenway. Only fluids where multiple samples yielded consistently high $\mathrm{Mg}$ concentrations and temperatures (within $10^{\circ} \mathrm{C}$ as measured by IGT samplers) are plotted (cf. Table 1). Mixing lines expected for conservative isenthalpic mixing between the vent fluids F3 (solid line) and seawater, and RMR4 (dashed line) and seawater are shown. Temperatures depicted by these mixing lines were calculated using the specific enthalpy data for a $3.2 \mathrm{wt} \% \mathrm{NaCl}$ solution at $200 \mathrm{bar}$ (Bischoff and Rosenbauer, 1985) and $\mathrm{Mg}$ concentrations are used as a conservative metric of mixing fraction between the hottest hydrothermal fluid and seawater compositions. The mixing lines assume a constant heat capacity for seawater below $200^{\circ} \mathrm{C}$ of $4.1 \mathrm{~J} / \mathrm{gK}$ (the actual change in heat capacity below $200{ }^{\circ} \mathrm{C}$ is $<5 \%$ ).

of measured temperatures and $\mathrm{Mg}$ concentrations with values predicted by the mixing model indicate a seawater source for the $\mathrm{Mg}$ in fluids. This strongly suggests that entrained seawater $\mathrm{Mg}$ behaves conservatively in many fluids during mixing even at relatively high upflow zone temperatures $\left(>250^{\circ} \mathrm{C}\right)$. Investigations of alteration assemblages recovered during ODP Leg 193 suggest that abundant chlorite formed in the subsurface is likely the result of $\mathrm{Mg}$ metasomatism during interactions of upwelling hydrothermal fluids with entrained seawater (Lackschewitz et al., 2004). While this contrasts with our finding that $\mathrm{Mg}$ may be largely conservative, the alteration assemblages likely reflect high cumulative water/rock ratios and we cannot exclude minor amounts of $\mathrm{Mg}$ fixation in upwelling fluids.

$\mathrm{SO}_{4}$ concentrations for the majority of Pual Ridge fluids are lower than predicted for conservative mixing of seawater and an endmember hydrothermal fluid devoid of $\mathrm{Mg}$ and $\mathrm{SO}_{4}$, yielding apparent negative endmember $\mathrm{SO}_{4}$ concentrations at zero $\mathrm{Mg}$ (Fig. 4). This further confirms fluids are venting with non-zero $\mathrm{Mg}$ concentrations and near zero $\mathrm{SO}_{4}$, consistent with non-conservative behavior of $\mathrm{SO}_{4}$ relative to $\mathrm{Mg}$ during the mixing process. The deviations to negative apparent $\mathrm{SO}_{4}$ endmembers are generally greater in fluids with higher Mg concentrations (Fig. 4), which reflect greater extents of subsurface seawater entrainment. Calculated endmember $\mathrm{Ca} / \mathrm{Cl}$ and $\mathrm{Sr} / \mathrm{Cl}$ ratios are consistently lower in such fluids also (Fig. 15a and 15b).
Collectively, these data indicate anhydrite precipitation is occurring during mixing due to its low solubility at elevated temperatures, thereby removing $\mathrm{Ca}$ (and co-precipitating $\mathrm{Sr}$ ) and seawater-derived $\mathrm{SO}_{4}$ (Mottl and Holland, 1978; Shikazono and Holland, 1983; Berndt et al., 1988; Mills and Tivey, 1999) and skewing calculated endmember concentrations. In some cases, Sr losses are so great that it is additionally removed from entrained seawater in addition to the supply of $\mathrm{Sr}$ available in the upwelling hydrothermal fluid, thereby yielding negative apparent endmember concentrations (e.g. SC1 vent, Table 2 and Fig. 15b). Such extreme $\mathrm{Sr}$ loss relative to $\mathrm{Mg}$ upon mixing provides an explanation for the implausible endmember ${ }^{87} \mathrm{Sr} /{ }^{86} \mathrm{Sr}$ ratio calculated at Snowcap (0.69768, Fig. 7) which is beyond the range possible for crustal materials (Banner, 2004).

In some cases, variable anhydrite precipitation is evident in multiple fluids sampled in close proximity to one another (e.g. RGR1 and RGR2 at Roger's Ruins, Figs. 2b and 4), suggesting that deposition may be occurring very near the seafloor or within sulfide structures themselves. Although mixing through 'leaky' walls of sulfide chimneys cannot be excluded at all vents (Haymon and Kastner, 1981; Goldfarb et al., 1983), consistently high Mg samples were collected at SM3 vent after the near complete removal of the sulfide chimney $(<1 \mathrm{~m}$ tall) and measured fluid temperatures before $\left(279^{\circ} \mathrm{C}\right)$ and after removal $\left(280-288^{\circ} \mathrm{C}\right)$ were similar. This suggests that some mixing is occurring beneath the seafloor and not within the removed structure at SM3. Shallow subsurface precipitation of anhydrite is entirely consistent with observations from ODP drill-cores which indicate that the abundant anhydrite deposits beneath the seafloor at PACMANUS contain partially seawaterderived $\mathrm{SO}_{4}$ (Roberts et al., 2003; Craddock and Bach, 2010). In cases where several vent fluids are in close proximity to one another and may be genetically related, the apparent variability in measured $\mathrm{Ca} / \mathrm{Cl}$ ratios due to anhydrite deposition is greatly reduced when such $\mathrm{Ca}$ loss is corrected. Using the deviations in measured $\mathrm{SO}_{4}$ concentrations from conservative behavior to estimate $\mathrm{SO}_{4}$ losses and assuming equimolar $\mathrm{Ca}$ loss for measured compositions, adjusted $\mathrm{Ca} / \mathrm{Cl}$ ratios in each case delineate trends between seawater and a much narrower range of endmember $\mathrm{Ca} / \mathrm{Cl}$ (Fig. 16). This suggests clustered vents at Roman Ruins, Roger's Ruins and Fenway reflect a common source fluid for each area that has undergone phase separation and partial segregation into fluids of differing $\mathrm{Cl}$ contents, followed by variable degrees of subsurface seawater entrainment into these fluids and concomitant anhydrite precipitation.

In addition to influence of mixing, some low temperature fluids at Pual Ridge, namely F5 vent and the single NE Pual fluid sampled (NP1), show evidence for extensive anhydrite dissolution and fixation of B. F5 vent $\left(80^{\circ} \mathrm{C}\right)$ was a poorly focused flow vent emanating from anhydrite sand/ talus on the north flank of the Fenway mound (Fig. 2c). In addition to the temperature and proximity considerations above, endmember alkali/Cl ratios (Table 3 and Fig. 11) at F5 are similar to those venting at the summit black smoker complex (F2, F3 and F4 vents), further suggesting the fluid is a mixture of the summit source fluid and seawater. 

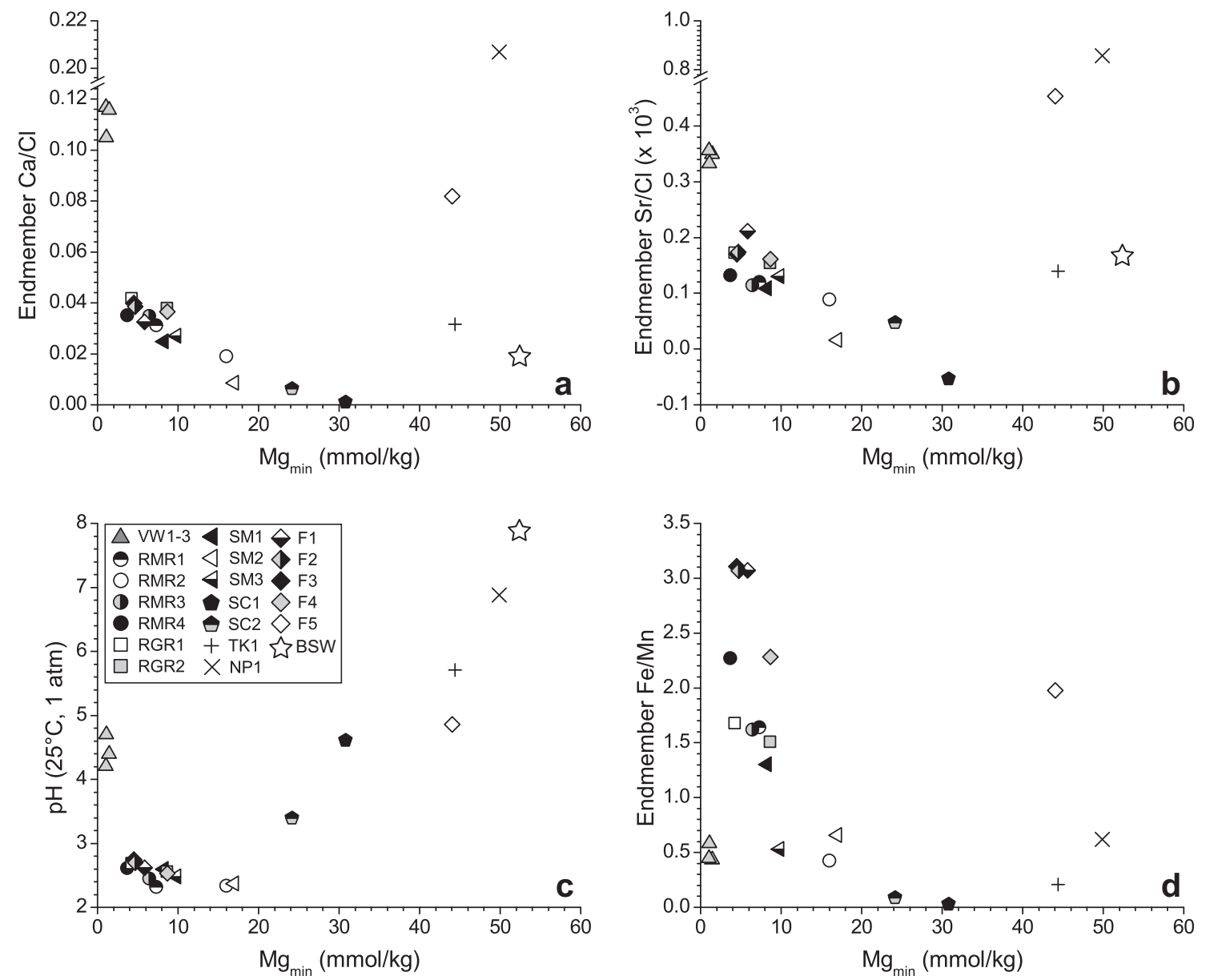

Fig. 15. Plots of the lowest $\mathrm{Mg}$ concentration $\left(\mathrm{Mg}_{\min }\right.$ ) measured at each vent vs. (a) endmember $\mathrm{Ca} / \mathrm{Cl}$ ratios, (b) endmember $\mathrm{Sr} / \mathrm{Cl}$ ratios, (c) lowest measured fluid $\mathrm{pH}\left(25^{\circ} \mathrm{C}\right)$ and $(\mathrm{d})$ endmember Fe/Mn ratios from Vienna Woods and Pual Ridge vent fluids. While these plots are unconventional, they are intended to show that at Pual Ridge, calculated endmember $\mathrm{Ca} / \mathrm{Cl}, \mathrm{Sr} / \mathrm{Cl}$ and $\mathrm{Fe} / \mathrm{Mn}$ ratios appear to decrease with increasing extents of subsurface seawater entrainment (accompanied by decreases in measured $\mathrm{pH}$ ) consistent with non-conservative behavior of $\mathrm{Ca}, \mathrm{Sr}$ and $\mathrm{Fe}$. NP1, F5 and TK1 are anomalous in that they have high endmember $\mathrm{Ca} / \mathrm{Cl}$ and $\mathrm{Sr} / \mathrm{Cl}$ ratios due to anhydrite dissolution (see text). BSW, bottom seawater.

The striking feature of F5 and NP1 compositions are measured $\mathrm{SO}_{4}$ concentrations (with near-seawater $\delta^{34} \mathrm{~S}_{\mathrm{SO}_{4}}$ values) that are elevated relative to concentrations predicted for conservative mixing of endmember fluids (devoid of $\mathrm{Mg}$ and $\mathrm{SO}_{4}$ ) and seawater (Fig. 4). In addition to high apparent endmember $\mathrm{Ca} / \mathrm{Cl}$ and $\mathrm{Sr} / \mathrm{Cl}$ ratios (Table 3 and Fig. 15a and 15b), these differences indicate that previously precipitated anhydrite is being re-dissolved by F5 and NP1 fluids, a likely consequence of the relatively low temperatures $\left(<80^{\circ} \mathrm{C}\right)$ resulting from high degrees of mixing. Dissolution of anhydrite by active low temperature fluids has previously only been observed at $9^{\circ} 50^{\prime} \mathrm{N}$ on the East Pacific Rise (McDermott and Von Damm, 2008) and highlights the transient nature of $\mathrm{Ca}, \mathrm{Sr}$ and $\mathrm{SO}_{4}$ sinks in anhydrite. F5 and NP1 also differ from higher temperature Pual Ridge fluids in the behavior of $\mathrm{B}$, as negative endmember concentrations are apparent upon extrapolation of measured $\mathrm{B}$ concentrations to zero $\mathrm{Mg}$ (Table 2). Like $\mathrm{Sr}$, this implies removal of seawater-derived B in F5 and NP1 fluids in addition to the $\mathrm{B}$ complement of their parent hydrothermal fluids. The most plausible explanation for these depletions is that low temperature fixation reactions have decreased the abundances of B prior to venting (Fig. 8). Laboratory and field studies have shown that fixation of B from seawater solutions occurs during low temperature $\left(<150^{\circ} \mathrm{C}\right)$ alteration of basaltic oceanic crust and likely sinks for B include alteration assemblages composed of ferric micas and smectites (Seyfried et al., 1984; Alt, 1995).

The pervasive nature of subsurface seawater entrainment apparent at Pual Ridge vent areas indicates a more open hydrologic regime beneath Pual Ridge compared to Vienna Woods and traditional MOR systems. Subsurface mixing at the TAG hydrothermal system was attributed to a 'leaky mound' model whereby seawater ingress is facilitated by the permeable anhydrite-sulfide breccia deposits of the TAG mound (Edmond et al., 1995; Humphris et al., 1995; Tivey et al., 1995; Humphris and Tivey, 2000). Aside from the Snowcap area, however, many of the mixed fluids at Pual Ridge are emanating from comparatively small sulfide structures atop rugged volcaniclastic flows. Meter-scale fissures were largely absent on the surface (Tivey et al., 2006), and it is possible fluid flow may instead be focused 


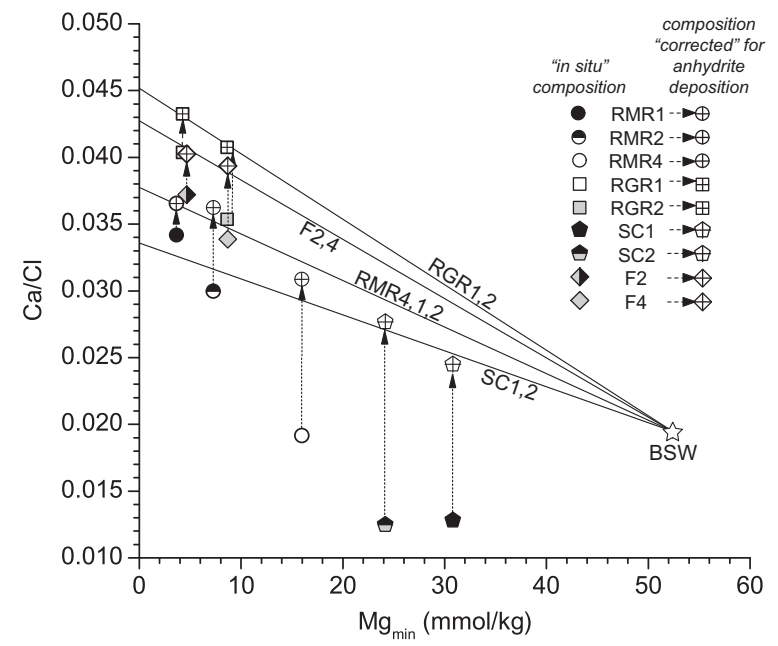

Fig. 16. Plot of lowest measured $\mathrm{Mg}$ concentrations $\left(\mathrm{Mg}_{\min }\right)$ vs. measured ("in situ") molar $\mathrm{Ca} / \mathrm{Cl}$ ratios and corresponding values "corrected" for anhydrite precipitation for closely co-located PACMANUS vent fluids. The "in situ" symbols denote the $\mathrm{Ca} / \mathrm{Cl}$ of each fluid calculated at $\mathrm{Mg}_{\min }$ from regressions of measured $\mathrm{Ca}$ and $\mathrm{Cl}$ concentrations. Deviations in the "in situ" $\mathrm{SO}_{4}$ concentration of these fluids (also calculated from measured $\mathrm{SO}_{4}{ }^{2-}$ regressions at $\mathrm{Mg}_{\text {min }}$ ) from conservative mixing of a hypothetical zero $\mathrm{Mg}$, zero $\mathrm{SO}_{4}{ }^{2-}$ fluid are calculated and used to the correct the $\mathrm{Ca} / \mathrm{Cl}$ ratios for molar equivalent $\mathrm{Ca}$ loss (vertical arrows). Regression lines for each group of anhydrite "corrected" compositions (grouped by vent area) are shown. BSW, bottom seawater.

through contact zones between lava flows or subsurface networks of fractures/conduits (Binns et al., 2007). The possibility that the blocky, highly vesicular and brecciated volcaniclastic nature of lavas at Pual Ridge contributes to the mixing regime must also be considered. Monecke et al. (2007) demonstrated that hydrothermal alteration in glassy dacites from the surface of Pual Ridge is influenced by primary volcanic textures and that some fluid flow occurs through vesicles interconnected by perlitic cracks/quench fractures. Enhanced permeability and fluid flow due to volcanic textures has been suggested for other back-arc hydrothermal systems (Ishibashi and Urabe, 1995), and may be an inherent consequence of the volatile-rich nature of precursor magmas in these environments.

\subsubsection{Secondary acidity generation}

An important consequence of the seawater entrainment and mixing beneath the seafloor at Pual Ridge is the deposition of iron sulfide minerals and production of secondary acidity in addition to that derived from magmatic fluid input at depth. Cooling induced by seawater mixing reduces both the stability of iron chloride complexes and the solubility of iron sulfides, resulting in the removal of $\mathrm{Fe}$ from solution. Iron sulfide deposition can be described by the reactions:

$$
\begin{aligned}
& \mathrm{Fe}^{2+}+\mathrm{H}_{2} \mathrm{~S}_{(\mathrm{aq})}=\mathrm{FeS}_{(\mathrm{s})}+2 \mathrm{H}^{+} \\
& \mathrm{Fe}^{2+}+2 \mathrm{H}_{2} \mathrm{~S}_{(\mathrm{aq})}=\mathrm{FeS}_{2(\mathrm{~s})}+2 \mathrm{H}^{+}+\mathrm{H}_{2(\mathrm{aq})} \\
& \mathrm{Cu}^{+}+\mathrm{Fe}^{2+}+2 \mathrm{H}_{2} \mathrm{~S}_{(\mathrm{aq})}=\mathrm{CuFeS}_{2(\mathrm{~s})}+0.5 \mathrm{H}_{2(\mathrm{aq})}+3 \mathrm{H}^{+}
\end{aligned}
$$

All of these reactions result in the generation of acidity. Because of the higher Fe content (several $\mathrm{mmol} / \mathrm{kg}$ ) of Pual Ridge fluids relative to $\mathrm{Cu}(<1 \mathrm{mmol} / \mathrm{kg}$, Craddock, 2008), deposition of pyrrhotite $(\mathrm{FeS})$ or pyrite $\left(\mathrm{FeS}_{2}\right)$ will likely have a greater impact of fluid $\mathrm{pH}$ than chalcopyrite $\left(\mathrm{CuFeS}_{2}\right)$. The extent of Fe precipitation at PACMANUS can be qualitatively assessed by examining $\mathrm{Fe} / \mathrm{Mn}$ ratios, since $\mathrm{Fe}$ precipitation from high temperature vent fluids during cooling is a relatively rapid process while Mn precipitation is kinetically inhibited (Seewald and Seyfried, 1990). Accordingly, initial Fe/Mn ratios of endmember hydrothermal fluids should show apparent decreases with increased cooling (due to mixing), resulting in substantial secondary acidity generation according to reactions (5)-(7). This trend is observed between fluids in several PACMANUS vent areas, where both $\mathrm{pH}$ and calculated endmember $\mathrm{Fe} / \mathrm{Mn}$ ratios are lower in fluids with higher $\mathrm{Mg}$ concentrations (Fig. 15c and 15d). These data suggest that differences in $\mathrm{pH}$ between co-located higher- and lower-temperature vent fluids reflect local modification by mixing-induced sulfide precipitation reactions that decrease $\mathrm{pH}$ below the already low values. The impact of these reactions is considerable given the extremely high $(\mathrm{mmol} / \mathrm{kg}) \mathrm{Fe}$ contents of Pual Ridge fluids.

The predominance of pyrite as the most abundant disseminated sulfide in ODP Leg 193 alteration lithologies and the apparent lack of abundant pyrrhotite in either the ODP drill-cores or chimney structures (Binns et al., 2007; Craddock, 2008) suggests that pyrite precipitation (reaction (6)) is responsible for Fe removal. This is also consistent with the relatively oxidizing redox conditions (as indicated by the aqueous $\mathrm{H}_{2}$ concentrations) that fall at the low end of the spectrum for ridge-crest hydrothermal fluids (Seyfried and Ding, 1995b; Von Damm, 1995). However, reaction (6) must produce equivalent moles of $\mathrm{H}_{2}$ for each mole of $\mathrm{Fe}$ deposited and $\mathrm{H}_{2}$ in Pual Ridge fluids does not approach the mmol/L levels expected for the quantities of Fe removal evident. Hence, an additional sink is required to consume $\mathrm{H}_{2}$. The only species present in sufficient quantities that is capable of oxidizing $\mathrm{H}_{2}$ in near-seafloor mixing zones is $\mathrm{SO}_{4}$, which is abundantly present in entrained seawater and as anhydrite. Reduction of $\mathrm{SO}_{4}$ by $\mathrm{H}_{2}$ can be represented by the reaction:

$\mathrm{HSO}_{4}{ }^{-}+\mathrm{H}^{+}+4 \mathrm{H}_{2(\mathrm{aq})}=\mathrm{H}_{2} \mathrm{~S}_{(\mathrm{aq})}+4 \mathrm{H}_{2} \mathrm{O}_{(\mathrm{l})}$

That each mole of $\mathrm{SO}_{4}$ requires 4 moles of $\mathrm{H}_{2}$ for complete reduction indicates that reaction (8) could be a very efficient sink for $\mathrm{H}_{2}$ generated by pyrite precipitation. Moreover, the kinetics of this reaction are greatly enhanced by the highly acidic nature of these fluids, requiring timescales of a few hours to reach near-equilibrium states at subsurface conditions (Ohmoto and Lasaga, 1982). The lack of positive deviations in $\delta^{34} \mathrm{~S}_{\mathrm{SO}_{4}}$ values (Table 1) expected for partial reduction of entrained seawater $\mathrm{SO}_{4}$ (Woodruff and Shanks, 1988; Shanks et al., 1995) suggests that anhydrite $\mathrm{SO}_{4}$ may be involved. In most cases, the decreases in $\mathrm{pH}$ observed for small amounts of seawater mixing are not as large as predicted from the apparent loss of Fe suggesting other reactions may be titrating secondary acidity generated by $\mathrm{Fe}$-sulfide precipitation. This may reflect 
remobilization of other metals (e.g. $\mathrm{Zn}, \mathrm{Au}, \mathrm{Ag}$ and $\mathrm{Pb}$ ), suggesting that 'zone refinement' may be occurring. Tivey et al. (1995) demonstrated that such remobilization of metals was occurring within the TAG hydrothermal mound as a direct result of modification of high temperature fluids by subsurface seawater entrainment.

\section{SUMMARY}

The chemical and isotopic compositions of vent fluid samples collected from hydrothermal vent fields located on the Manus Spreading Center (Vienna Woods) and Pual Ridge (PACMANUS and NE Pual) in the Manus back-arc basin have been determined. The sites differ substantially in both substrate type (mafic at Vienna Woods vs. felsic at Pual Ridge) and proximity to the New Britain subduction zone (Pual Ridge is closest). Six areas of venting were sampled at PACMANUS, including a large area (Fenway) discovered during this expedition where vigorous 2-phase venting of $358^{\circ} \mathrm{C}$ fluid was observed, and one low temperature fluid was sampled at NE Pual. Distinct differences between the chemistries of fluids at Vienna Woods and Pual Ridge indicate that while processes of water-rock interaction and phase separation are common to both, inputs of acidic magmatic fluids and entrainment of seawater into the subsurface exert substantial influence on fluid compositions at Pual Ridge.

All fluids at Vienna Woods are characterized by a high degree of uniformity and are compositionally similar to mid-ocean ridge basalt-hosted hydrothermal systems. Since the site was first sampled in 1990, the major element composition of fluids there have remained relatively constant. High absolute abundances and differing molar ratios of 'soluble' alkali elements and B in Pual Ridge fluids relative to those at Vienna Woods reflect hydrothermal interaction with the more arc-like crust of the Eastern Manus Volcanic Zone. Fluids from Pual Ridge display $\mathrm{Cl}$ variability which, combined with trends of 'soluble' elements and dissolved gas abundances with $\mathrm{Cl}$, indicates that fluids have undergone phase separation even though measured exit temperatures for most vents are much lower than the 2-phase boundary for seawater. Vienna Woods fluids are substantially cooler than the 2-phase boundary, hence either extensive conductive cooling must be occurring or the chronic venting of high $\mathrm{Cl}$ fluids there reflects residual brine entrainment.

Measured $\mathrm{pH}\left(25^{\circ} \mathrm{C}\right)$ values in low $\mathrm{Mg}$ fluids at Pual Ridge differ from those of Vienna Woods in that values are far lower than that expected for equilibrium buffering by host rock mineral assemblages, suggesting the involvement of magmatic fluids containing acid-volatile constituents (i.e. $\mathrm{SO}_{2}$ ). The extremely high dissolved metal contents and ubiquitous negative $\delta \mathrm{D}_{\mathrm{H}_{2} \mathrm{O}}$ values found at PACMANUS are also consistent with the input of highly acidic magmatic fluids at depth to seawater-derived hydrothermal fluids. However, extremely high $\mathrm{CO}_{2}$ concentrations (up to $274 \mathrm{mmol} / \mathrm{kg}$ ) and negative $\delta^{34} \mathrm{~S}_{\mathrm{H}_{2} \mathrm{~S}}$ values (down to $-2.7 \%$ ) - both of which are strongly indicative of magmatic inputs - are limited to the Snowcap, Satanic Mills and Fenway vent areas. $\delta^{34} \mathrm{~S}_{\mathrm{SO}_{4}}$ values show no indi- cation of $\mathrm{SO}_{4}$ derived from magmatic sources, but removal of such $\mathrm{SO}_{4}$ to anhydrite at depth in the high temperature reaction zone may have completely erased this signal. $\delta^{13} \mathrm{C}$ values of $\mathrm{CO}_{2}$ at PACMANUS are higher than those of Vienna Woods indicating a greater influence of slabderived carbon at Pual Ridge, which is located much closer to the active New Britain Arc.

The ubiquity of non-zero measured $\mathrm{Mg}$ concentrations in Pual Ridge fluids relative to Vienna Woods indicates that subsurface entrainment of seawater into hydrothermal fluids during upflow is pervasive at the former site and the various vent areas delineate a spectrum of subsurface mixing regimes. Trends of increasing non-conservative $\mathrm{SO}_{4}$ behavior, decreasing endmember $\mathrm{Ca} / \mathrm{Cl}$ and $\mathrm{Sr} / \mathrm{Cl}$ ratios with increased seawater admixing within vent areas demonstrate that subsurface precipitation of anhydrite is commonplace and is substantially modifying the $\mathrm{Ca}$ and $\mathrm{Sr}$ fluxes of high temperature fluids. Furthermore, these observations are accompanied in several cases by trends of decreasing endmember $\mathrm{Fe} / \mathrm{Mn}$ ratios and decreasing measured $\mathrm{pH}$ $\left(25^{\circ} \mathrm{C}\right)$ with increasing $\mathrm{Mg}$, implying that iron sulfide deposition is also occurring in the subsurface and is leading to secondary acidity production.

\section{ACKNOWLEDGMENTS}

The authors are grateful to the crew of the R/V Melville and ROV Jason II technical group for their expertise and assistance in completion of a very successful dive program. We would also like to thank Maurice Tivey and the Autonomous Benthic Explorer (ABE) technical group for providing SM2000 bathymetric maps for our manuscript prior to publication. This manuscript benefited greatly from numerous invaluable discussions with Margaret K. Tivey. We would like to acknowledge helpful reviews by Joseph Resing and two other anonymous reviewers, which greatly improved the presentation and discussion of our research, in addition to helpful comments from the Associate Editor, J.-I. Ishibashi. This study received financial support from NSF Grant OCE-0327448, the WHOI Deep Ocean Exploration Institute Graduate Fellowship (to E.P. Reeves) and the Ocean Drilling Program Schlanger Fellowship (to P.R. Craddock).

\section{REFERENCES}

Aiuppa A., Baker D. R. and Webster J. D. (2009) Halogens in volcanic systems. Chem. Geol. 263(1-4), 1-18.

Albarède F., Michard A., Minster J. F. and Michard G. (1981) ${ }^{87} \mathrm{Sr} /{ }^{86} \mathrm{Sr}$ ratios in hydrothermal waters and deposits from the East Pacific Rise at $21^{\circ}$ N. Earth Planet. Sci. Lett. 55, 229-236.

Alt J. and Bach W. (2003) Alteration of ocean crust. In Dahlem Workshop Report: Energy and Mass Transfer in Marine Hydrothermal Systems, vol. 89 (eds. P. E. Halbach, V. Tunnicliffe and J. R. Hein). Dahlem University Press, pp. 7-27.

Alt J. C. (1995) Subseafloor processes in mid-ocean ridge hydrothermal systems. In Seafloor Hydrothermal Systems: Physical, Chemical, Biological, and Geological Interactions, vol. 91 (eds. S. E. Humphris, R. A. Zierenberg, L. S. Mullineaux and R. E. Thomson). AGU Monograph. American Geophysical Union, pp. $85-114$.

Alt J. C. and Teagle D. A. H. (1999) The uptake of carbon during alteration of ocean crust. Geochim. Cosmochim. Acta 63(10), $1527-1535$. 
Arnorsson S., Gronvold K. and Sigurdsson S. (1978) Aquifer chemistry of four high-temperature geothermal systems in Iceland. Geochim. Cosmochim. Acta 42(5), 523-536.

Arnorsson S. and Andresdottir A. (1995) Processes controlling the distribution of boron and chlorine in natural waters in Iceland. Geochim. Cosmochim. Acta 59(20), 4125-4146.

Audetat A., Gunther D. and Heinrich C. A. (1998) Formation of a magmatic-hydrothermal ore deposit: insights with LA-ICP-MS analysis of fluid inclusions. Science 279(5359), 2091-2094.

Auzende J. M., Urabe T., Ruellan E., Chabroux D., Charlou J. L., Gena K., Gamo T., Henry K., Matsubayashi O. and Matsumoto T., et al. (1996) "Shinkai 6500" dives in the Manus Basin: new STARMER Japanese-French program. JAMSTEC J. Deep Sea Res. 12, 323-334.

Auzende J. M., Hashimoto J., Fialamedioni A. and Ohta S. (1997) In situ geological and biological study of two hydrothermal zones in the Manus Basin (Papua New Guinea). C. R. Acad. Sci., Ser. Ia: Sci. Terre Planets 325(8), 585-591.

Auzende J. M., Ishibashi J., Beaudoin Y., Charlou J. L., Delteil J., Donval J. P., Fouquet Y., Gouillou J. P., Ildefonse B. and Kimura H., et al. (2000) The eastern and western tips of Manus Basin (Papua, New Guinea) explored by submersible: MANAUTE cruise. C. R. Acad. Sci., Ser. Ia: Sci. Terre Planets 331(2), 119-126.

Bach W., Roberts S., Vanko D. A., Binns R. A., Yeats C. J., Craddock P. R. and Humphris S. E. (2003) Controls of fluid chemistry and complexation on rare-earth element contents of anhydrite from the PACMANUS subseafloor hydrothermal system, Manus Basin, Papua New Guinea. Miner. Deposita 38(8), 916-935.

Banner J. L. (2004) Radiogenic isotopes: systematics and applications to earth surface processes and chemical stratigraphy. Earth Sci. Rev. 65(3-4), 141-194.

Berndt M. E., Seyfried W. E. and Beck J. W. (1988) Hydrothermal alteration processes at midocean ridges: experimental and theoretical constraints from $\mathrm{Ca}$ and $\mathrm{Sr}$ exchange reactions and $\mathrm{Sr}$ isotopic ratios. J. Geophys. Res. 93(B5), 4573-4583.

Berndt M. E., Seyfried W. E. and Janecky D. R. (1989) Plagioclase and epidote buffering of cation ratios in mid-ocean ridge hydrothermal fluids - experimental results in and near the supercritical region. Geochim. Cosmochim. Acta 53(9), 22832300.

Berndt M. E. and Seyfried W. E. (1990) Boron, bromine, and other trace elements as clues to the fate of chlorine in mid-ocean ridge vent fluids. Geochim. Cosmochim. Acta 54, 2235-2245.

Berndt M. E. and Seyfried W. E. (1993) Calcium and sodium exchange during hydrothermal alteration of calcic plagioclase at $400{ }^{\circ} \mathrm{C}$ and 400 bars. Geochim. Cosmochim. Acta 57(18), 4445-4451.

Berndt M. E., Seal R. R., Shanks W. C. and Seyfried W. E. (1996) Hydrogen isotope systematics of phase separation in submarine hydrothermal systems: experimental calibration and theoretical models. Geochim. Cosmochim. Acta 60(9), 1595-1604.

Binns R. A. and Scott S. D. (1993) Actively forming polymetallic sulfide deposits associated with felsic volcanic-rocks in the Eastern Manus Back-Arc Basin, Papua New Guinea. Econ. Geol. 88(8), 2226-2236.

Binns, R. A., Scott, S. D., Gemmell, J. B., Crook, K., and Shipboard Scientific Party (1997) The SuSu Knolls Hydrothermal Field, Eastern Manus Basin, Papua New Guinea. EOS Trans. $A G U, 78(722)$, Fall Meet. Suppl. \#V22E-02 (abstr.)

Binns R. A., Barriga F. J. A. S. and Miller D. J. (2007) Leg 193 synthesis: anatomy of an active felsic-hosted hydrothermal system, Eastern Manus Basin, Papua New Guinea. In Proceedings of the Ocean Drilling Program, Scientific Results, vol. 193 (eds. F. J. A. S. Barriga, R. A. Binns, D. J. Miller and P. M. Herzig). Ocean Drilling Program, pp. 1-71.

Bischoff J. L. and Dickson F. W. (1975) Seawater-basalt interaction at $200{ }^{\circ} \mathrm{C}$ and 500 bars: implications for origin of sea-floor heavy-metal deposits and regulation of seawater chemistry. Earth Planet. Sci. Lett. 25, 385-397.

Bischoff J. L. and Seyfried W. E. (1978) Hydrothermal chemistry of seawater from 25 to $350^{\circ} \mathrm{C}$. Am. J. Sci. 278, 838-860.

Bischoff J. L. and Pitzer K. S. (1985) Phase relations and adiabats in boiling seafloor geothermal systems. Earth Planet. Sci. Lett. 75(4), 327-338.

Bischoff J. L. and Rosenbauer R. J. (1985) An empirical equation of state for hydrothermal seawater (3.2 percent $\mathrm{NaCl}) . \mathrm{Am}$. J. Sci. 285(8), 725-763.

Both R., Crook K., Taylor B., Brogan S., Chappell B., Frankel E., Liu L., Sinton J. and Tiffin D. (1986) Hydrothermal chimneys and associated fauna in the Manus back-arc basin, Papua New Guinea. EOS Trans. AGU 67, 489-491.

Bowers T. S. and Taylor H. P. (1985) An integrated chemical and stable-isotope model of the origin of midocean ridge hot spring systems. J. Geophys. Res. 90(B14), 12583-12606.

Bowers T. S. (1989) Stable isotope signatures of water-rock interaction in mid-ocean ridge hydrothermal systems: sulfur, oxygen and hydrogen. J. Geophys. Res. 94(B5), 5775-5786.

Brimhall G. H. and Ghiorso M. S. (1983) Origin and ore-forming consequences of the advanced argillic alteration process in hypogene environments by magmatic gas contamination of meteoric fluids. Econ. Geol. 78(1), 73-90.

Burnham C. W. (1979) Magmas and hydrothermal fluids. In Geochemistry of Hydrothermal Ore Deposits (ed. H. L. Barnes). Wiley, pp. 71-136.

Butterfield D., Seyfried W. E. and Lilley M. (2003) Composition and evolution of hydrothermal fluids. In Dahlem Workshop Report: Energy and Mass Transfer in Marine Hydrothermal Systems, vol. 89 (eds. P. E. Halbach, V. Tunnicliffe and J. R. Hein). Dahlem University Press, pp. 123-161.

Butterfield D. A., Massoth G. J., McDuff R. E., Lupton J. E. and Lilley M. D. (1990) Geochemistry of hydrothermal fluids from Axial Seamount Hydrothermal Emissions Study vent field, Juan de Fuca Ridge: subseafloor boiling and subsequent fluidrock interaction. J. Geophys. Res.: Solid Earth Planets 95(B8), 12895-12921.

Butterfield D. A. and Massoth G. J. (1994) Geochemistry of North Cleft Segment vent fluids - temporal changes in chlorinity and their possible relation to recent volcanism. J. Geophys. Res.: Solid Earth 99(B3), 4951-4968.

Butterfield D. A., McDuff R. E., Mottl M. J., Lilley M. D., Lupton J. E. and Massoth G. J. (1994) Gradients in the composition of hydrothermal fluids from the Endeavour Segment vent field: phase separation and brine loss. J. Geophys. Res.: Solid Earth 99(B5), 9561-9583.

Butterfield D. A., Jonasson I. R., Massoth G. J., Feely R. A., Roe K. K., Embley R. E., Holden J. F., McDuff R. E., Lilley M. D. and Delaney J. R. (1997) Seafloor eruptions and evolution of hydrothermal fluid chemistry. Philos. Trans. R. Soc. Lond. A: Math. Phys. Eng. Sci. 355(1723), 369-386.

Carroll M. R. and Rutherford M. J. (1988) Sulfur speciation in hydrous experimental glasses of varying oxidation state: results from measured wavelength shifts of sulfur X-rays. Am. Mineral. 73(7-8), 845-849.

Carroll M. R. and Webster J. D. (1994) Solubilities of sulfur, noble gases, nitrogen, chlorine, and fluorine in magmas. In Volatiles in Magmas, vol. 30 (eds. M. R. Carroll and J. R. Holloway). Reviews in Mineralogy. Mineralogical Society of America, pp. 231-279. 
Cartigny P., Jendrzejewski N., Pineau F., Petit E. and Javoy M. (2001) Volatile (C, N, Ar) variability in MORB and the respective roles of mantle source heterogeneity and degassing: the case of the Southwest Indian Ridge. Earth Planet. Sci. Lett. 194(1-2), 241-257.

Charlou J. L., Donval J. P., Jean-Baptiste P. and Dapoigny A. (1996) Gases and helium isotopes in high temperature solutions sampled before and after ODP Leg 158 drilling at TAG hydrothermal field $\left(26^{\circ} \mathrm{N}, \mathrm{MAR}\right)$. Geophys. Res. Lett. 23(23), 3491-3494.

Charlou J. L., Donval J. P., Fouquet Y., Jean-Baptiste P. and Holm N. (2002) Geochemistry of high $\mathrm{H}_{2}$ and $\mathrm{CH}_{4}$ vent fluids issuing from ultramafic rocks at the Rainbow hydrothermal field (36 $14^{\prime}$ N, MAR). Chem. Geol. 191(4), 345-359.

Cheminée J. L., Stoffers P., McMurtry G., Richnow H., Puteanus D. and Sedwick P. (1991) Gas-rich submarine exhalations during the 1989 eruption of Macdonald Seamount. Earth Planet. Sci. Lett. 107(2), 318-327.

Cline J. S. and Bodnar R. J. (1991) Can economic porphyry copper mineralization be generated by a typical calc-alkaline melt? $J$. Geophys. Res.: Solid Earth Planets 96(B5), 8113-8126.

Coltice N., Simon L. and Lecuyer C. (2004) Carbon isotope cycle and mantle structure. Geophys. Res. Lett. 31(5).

Corliss J. B., Dymond J., Gordon L. I., Edmond J. M., Von Herzen R. P., Ballard R. D., Green K., Williams D., Bainbridge A. and Crane K., et al. (1979) Submarine thermal springs on the Galápagos Rift. Science 203, 1073-1083.

Craddock P. R. (2008) Geochemical tracers of processes affecting the formation of seafloor hydrothermal fluids and deposits in the Manus back-arc basin. Ph.D. thesis, MIT-WHOI Joint Program in Oceanography, MIT.

Craddock P. R. and Bach W. (2010) Insights into magmatichydrothermal processes in the Manus back-arc basin as recorded by anhydrite. Geochim. Cosmochim. Acta 74, 5514 5536.

Craddock P. R., Bach W., Seewald J. S., Rouxel O. J., Reeves E. and Tivey M. K. (2010) Rare earth element abundances in hydrothermal fluids from the Manus Basin, Papua New Guinea: indicators of sub-seafloor hydrothermal processes in back-arc basins. Geochim. Cosmochim. Acta 74, 5494-5513.

Craig H. and Gordon L. I. (1965) Deuterium and oxygen 18 variations in the ocean and marine atmosphere. In Stable Isotopes in Oceanographic Studies and Paleotemperatures (ed. E. Tongiogi). Consiglio Nazionale Delle Ricerche, Laboratorio Di Geologia Nucleare, Pisa, pp. 9-130.

Craig H. (1970) Abyssal carbon-13 in the South Pacific. J. Geophys. Res. 75(3), 691-695.

Cruse A. M. and Seewald J. S. (2006) Geochemistry of lowmolecular weight hydrocarbons in hydrothermal fluids from Middle Valley, northern Juan de Fuca Ridge. Geochim. Cosmochim. Acta 70(8), 2073-2092.

de Ronde C. E. J. (1995) Fluid chemistry and isotopic characteristics of seafloor hydrothermal systems and associated VMS deposits: potential for magmatic contributions. In Magmas, Fluids, and Ore Deposits: MAC Short Course Series, vol. 23 (ed. J. F. H. Thompson). Mineralogical Association of Canada, pp. 479-509.

de Ronde C. E. J., Hannington M. D., Stoffers P., Wright I. C., Ditchburn R. G., Reyes A. G., Baker E. T., Massoth G. J., Lupton J. E. and Walker S. L., et al. (2005) Evolution of a submarine magmatic-hydrothermal system: Brothers volcano, southern Kermadec arc, New Zealand. Econ. Geol. 100(6), 1097-1133.

Douville E., Bienvenu P., Charlou J. L., Donval J. P., Fouquet Y., Appriou P. and Gamo T. (1999a) Yttrium and rare earth elements in fluids from various deep-sea hydrothermal systems. Geochim. Cosmochim. Acta 63(5), 627-643.

Douville E., Charlou J. L., Donval J. P., Hureau D. and Appriou P. (1999b) As and Sb behaviour in fluids from various deep-sea hydrothermal systems. C. R. Acad. Sci., Ser. Ia: Sci. Terre Planets 328(2), 97-104.

Drummond S. E. (1981) Boiling and mixing of hydrothermal fluids: chemical effects on mineral precipitation. Ph.D. dissertation, Penn. State University.

Edmond J. M., Measures C., McDuff R. E., Chan L. H., Collier R., Grant B., Gordon L. I. and Corliss J. B. (1979a) Ridge crest hydrothermal activity and the balances of the major and minor elements in the ocean: the Galápagos data. Earth Planet. Sci. Lett. 46(1), 1-18.

Edmond J. M., Measures C., Mangum B., Grant B., Sclater F. R., Collier R., Hudson A., Gordon L. I. and Corliss J. B. (1979b) Formation of metal-rich deposits at ridge crests. Earth Planet. Sci. Lett. 46(1), 19-30.

Edmond J. M., Campbell A. C., Palmer M. R., Klinkhammer G., German C., Edmonds H. N., Elderfield H., Thompson G. and Rona P. (1995) Time series studies of vent fluids from the TAG and MARK sites $(1986,1990)$ Mid-Atlantic Ridge: a new solution chemistry model and a mechanism for $\mathrm{Cu} / \mathrm{Zn}$ zonation in massive sulphide ore-bodies. In Hydrothermal Vents and Processes (eds. L. Parson and J. R. Dixon). Geological Society Special Publication No. 87, pp. 77-86.

Eickmann B., Bach W., Rosner M. and Peckmann J. (2009) Geochemical constraints on the modes of carbonate precipitation in peridotites from the Logatchev Hydrothermal Vent Field and Gakkel Ridge. Chem. Geol. 268(1-2), 97-106.

Embley R. W., Chadwick W. W., Baker E. T., Butterfield D. A., Resing J. A., de Ronde C. E. J., Tunnicliffe V., Lupton J. E., Juniper S. K. and Rubin K. H., et al. (2006) Long-term eruptive activity at a submarine arc volcano. Nature 441(7092), 494-497.

Fouquet Y., Von Stackelberg U., Charlou J. L., Donval J. P., Erzinger J., Foucher J. P., Herzig P., Muhe R., Soakai S. and Wiedicke M., et al. (1991a) Hydrothermal activity and metallogenesis in the Lau Back-Arc Basin. Nature 349(6312), 778781.

Fouquet Y., Von Stackelberg U., Charlou J. L., Donval J. P., Foucher J. P., Erzinger J., Herzig P., Muhe R., Wiedicke M. and Soakai S., et al. (1991b) Hydrothermal activity in the Lau Back-Arc Basin — sulfides and water chemistry. Geology 19(4), 303-306.

Fouquet Y., Von Stackelberg U., Charlou J. L., Erzinger J., Herzig P. M., Muhe R. and Wiedicke M. (1993) Metallogenesis in back-arc environments- the Lau Basin example. Econ. Geol. 88(8), 2154-2181.

Fournier R. O. (1983) A method of calculating quartz solubilities in aqueous sodium-chloride solutions. Geochim. Cosmochim. Acta 47(3), 579-586.

Fourre E., Jean-Baptiste P., Charlou J. L., Donval J. P. and Ishibashi J. I. (2006) Helium isotopic composition of hydrothermal fluids from the Manus back-arc Basin, Papua New Guinea. Geochem. J. 40(3), 245-252.

Foustoukos D. I. and Seyfried W. E. (2007a) Quartz solubility in the two-phase and critical region of the $\mathrm{NaCl}-\mathrm{KCl}-\mathrm{H}_{2} \mathrm{O}$ system: implications for submarine hydrothermal vent systems at $9^{\circ} 50^{\prime} \mathrm{N}$ East Pacific Rise. Geochim. Cosmochim. Acta 71(1), 186-201.

Foustoukos D. I. and Seyfried W. E. (2007b) Fluid phase separation processes in submarine hydrothermal systems. In Fluid-Fluid Interactions, vol. 65 (eds. A. Liebscher and C. A. Heinrich). Reviews in Mineralogy \& Geochemistry. Mineralogical Society of America, pp. 213-239. 
Foustoukos D. I. and Seyfried W. E. (2007c) Trace element partitioning between vapor, brine and halite under extreme phase separation conditions. Geochim. Cosmochim. Acta 71(8), 2056-2071.

Franklin J., Lyndon J. W. and Sangster D. F. (1981) Volcanicassociated massive sulfide deposits. Econ. Geol. 75, 485-627.

Gallant R. M. and Von Damm K. L. (2006) Geochemical controls on hydrothermal fluids from the Kairei and Edmond Vent Fields, $23^{\circ}-25^{\circ} \mathrm{S}$, Central Indian Ridge. Geochem. Geophys. Geosyst. 7(6), Q06018. doi:10.1029/2005GC001067.

Galluccio J., Maclean J., Mcfadyen S., Moore J., Saccocia P. and Seewald J. (2009) The mobility of fluoride in back-arc hydrothermal systems. Eos Trans. AGU 90(52), Fall Meet. Suppl. \#OS13A-1182 (abstr.).

Gamo T., Sakai H., Ishibashi J., Nakayama E., Isshiki K., Matsuura H., Shitashima K., Takeuchi K. and Ohta S. (1993) Hydrothermal plumes in the Eastern Manus Basin, Bismarck $\mathrm{Sea}-\mathrm{CH}_{4}, \mathrm{Mn}, \mathrm{Al}$ and $\mathrm{pH}$ anomalies. Deep Sea Res. Part I 40(11-12), 2335-2349.

Gamo T., Okamura K., Charlou J. L., Urabe T., Auzende J. M., Cruise S. S. P. O. T. M., Ishibashi J., Shitashima K. and Kodama Y. (1996a) Chemical exploration of hydrothermal activity in the Manus Basin, Papua New Guinea (ManusFlux Cruise). JAMSTEC J. Deep Sea Res. 12, 335-345.

Gamo T., Okamura K., Kodama T., Charlou J. L., Urabe T., Auzende J. M., Ishibashi J. and Party A. T. S. S. (1996b) Chemical characteristics of hydrothermal fluids from the Manus back-arc basin, Papua New Guinea: I. Major chemical components. EOS Trans. AGU 77(W116), WPGM Suppl. \#T32A-5 (abstr.).

Gamo T., Chiba H., Masuda H., Edmonds H. N., Fujioka K., Kodama Y., Nanba H. and Sano Y. (1996c) Chemical characteristics of hydrothermal fluids from the TAG mound of the Mid-Atlantic Ridge in August 1994: implications for spatial and temporal variability of hydrothermal activity. Geophys. Res. Lett. 23(23), 3483-3486.

Gamo T., Okamura K., Charlou J. L., Urabe T., Auzende J. M., Ishibashi J., Shitashima K. and Chiba H. (1997) Acidic and sulfate-rich hydrothermal fluids from the Manus back-arc basin, Papua New Guinea. Geology 25(2), 139-142.

Gamo T., Ishibashi J., Tsunogai U., Okamura K. and Chiba H. (2006) Unique geochemistry of submarine hydrothermal fluids from arc-back-arc settings of the western Pacific. In Back-Arc Spreading Systems: Geological, Biological, Chemical, and Physical Interactions, vol. 166 (eds. D. M. Christie, C. R. Fisher, S.M. Lee and S. Givens). AGU Monograph. American Geophysical Union, pp. 147-161.

Gena K., Mizuta T., Ishiyama D. and Urabe T. (2001) Acidsulphate type alteration and mineralization in the DESMOS caldera, Manus back-arc basin, Papua New Guinea. Resour. Geol. 51(1), 31-44.

German C. and Von Damm K. L. (2003) Hydrothermal processes. In The Treatise on Geochemistry, vol. 6 (eds. K. K. Turekian and H. D. Holland). Elsevier, pp. 181-222.

Giggenbach W. F. (1992) Isotopic shifts in waters from geothermal and volcanic systems along convergent plate boundaries and their origin. Earth Planet. Sci. Lett. 113(4), 495-510.

Goff F. and McMurtry G. M. (2000) Tritium and stable isotopes of magmatic waters. J. Volcanol. Geoth. Res. 97(1-4), 347-396.

Goldfarb M. S., Converse D. R., Holland H. D. and Edmond J. M. (1983) The genesis of hot spring deposits on the East Pacific Rise, $21^{\circ}$ N. Econ. Geol. Monogr. 5, 184-197.

Hajash A. and Chandler G. W. (1982) An experimental investigation of high-temperature interactions between seawater and rhyolite, andesite, basalt and peridotite. Contrib. Mineral. Petrol. 78(3), 240-254.
Hannington M., Herzig P., Stoffers P., Scholten J., Botz R., GarbeSchonberg D., Jonasson I. R. and Roest W. (2001) First observations of high-temperature submarine hydrothermal vents and massive anhydrite deposits off the north coast of Iceland. Mar. Geol. 177(3-4), 199-220.

Haymon R. M. and Kastner M. (1981) Hot-spring deposits on the East Pacific Rise at $21^{\circ} \mathrm{N}$ - preliminary description of mineralogy and genesis. Earth Planet. Sci. Lett. 53(3), 363-381.

Hedenquist J. W. and Lowenstern J. B. (1994) The role of magmas in the formation of hydrothermal ore deposits. Nature 370(6490), 519-527.

Herzig P. M. and Hannington M. D. (1995) Polymetallic massive sulfides at the modern seafloor-a review. Ore Geol. Rev. 10(2), 95-115.

Holland H. D. (1965) Some applications of thermochemical data to problems in ore deposits: II. Mineral assemblages and the composition of ore-forming fluids. Econ. Geol. 60(6), 11011166

Horita J., Cole D. R. and Wesolowski D. J. (1995) The activitycomposition relationship of oxygen and hydrogen isotopes in aqueous salt solutions: III. Vapor-liquid water equilibration of $\mathrm{NaCl}$ solutions to $350^{\circ} \mathrm{C}$. Geochim. Cosmochim. Acta 59(6), 1139-1151.

Hrischeva E., Scott S. D. and Weston R. (2007) Metalliferous sediments associated with presently forming volcanogenic massive sulfides: the SuSu knolls hydrothermal field, eastern manus basin, Papua New Guinea. Econ. Geol. 102(1), 55-73.

Humphris S. E., Herzig P. M., Miller D. J., Alt J. C., Becker K., Brown D., Brugmann G., Chiba H., Fouquet Y. and Gemmell J. B., et al. (1995) The internal structure of an active sea-floor massive sulfide deposit. Nature 377(6551), 713-716.

Humphris S. E. and Tivey M. K. (2000) A synthesis of geological and geochemical investigations of the TAG hydrothermal field: insights into fluid flow and mixing processes in a hydrothermal system. In Ophiolites and Oceanic Crust: New Insights from Field Studies and the Ocean Drilling Program (eds. Y. Dilek, E. M. Moores, D. Elthon and A. Nicholas). Geological Society of America, Special Paper 349, pp. 213-235.

Ishibashi J. I., Wakita H., Nojiri Y., Grimaud D., Jeanbaptiste P., Gamo T., Auzende J. M. and Urabe T. (1994) Helium and carbon geochemistry of hydrothermal fluids from the North Fiji Basin spreading ridge (Southwest Pacific). Earth Planet. Sci. Lett. 128(3-4), 183-197.

Ishibashi J. I. and Urabe T. (1995) Hydrothermal activity related to arc-backarc magmatism in the Western Pacific. In Backarc Basins: Tectonics and Magmatism (ed. B. Taylor). Plenum Press, pp. 451-495.

Ishibashi J. I., Wakita K., Okamura K., Gamo T., Shitashima K., Charlou J. L., Donval J. P., Jean-Baptiste P. and Party A. T. S. S. (1996) Chemical characteristics of hydrothermal fluids from the Manus back-arc basin, Papua New Guinea: II. Gas components. EOS Trans. AGU 77(W116), WPGM Suppl. \#T32A-6 (abstr.).

Iwasaki I. and Ozawa T. (1960) Genesis of sulfate in acid hot spring. Bull. Chem. Soc. Jpn. 33(7), 1018-1019.

Javoy M., Pineau F. and Iiyama J. T. (1978) Experimental determination of the isotopic fractionation between gaseous $\mathrm{CO}_{2}$ and carbon dissolved in the tholeiitic magma: a preliminary study. Contrib. Mineral. Petrol. 67, 35-39.

Kamenetsky V. S., Binns R. A., Gemmell J. B., Crawford A. J., Mernagh T. P., Maas R. and Steele D. (2001) Parental basaltic melts and fluids in eastern Manus backarc Basin: implications for hydrothermal mineralisation. Earth Planet. Sci. Lett. 184(34), 685-702.

Kamenetsky V. S., Davidson P., Mernagh T. P., Crawford A. J., Gemmell J. B., Portnyagin M. V. and Shinjo R. (2002) Fluid 
bubbles in melt inclusions and pillow-rim glasses: high-temperature precursors to hydrothermal fluids? Chem. Geol. 183(1-4), 349-364.

Karl D. M., McMurtry G. M., Malahoff A. and Garcia M. O. (1988) Loihi-Seamount, Hawaii: a mid-plate volcano with a distinctive hydrothermal system. Nature 335(6190), 532-535.

Kelley D. S. and Früh-Green G. (2000) Volatiles in mid-ocean ridge environments. In Ophiolites and Ocean Crust: Insights from Field Studies and the Ocean Drilling Program (eds. Y. Dilek, E. M. Moores, D. Elthon and A. Nicholas). Geological Society of America, Special Paper 349, pp. 237-260.

Kelley D. S., Lilley M. D. and Früh-Green G. L. (2004) Volatiles in submarine environments: food for life. In The Subseafloor Biosphere at Mid-Ocean Ridges, vol. 144 (eds. W. S. D. Wilcock, E. F. DeLong, D. S. Kelley, J. A. Baross and S. C. Cary). AGU Monograph. American Geophysical Union, pp. 167-189.

Kendall C. and Coplen T. B. (1985) Multisample conversion of water to hydrogen by zinc for stable isotope determination. Anal. Chem. 57(7), 1437-1440.

Kusakabe M., Komoda Y., Takano B. and Abiko T. (2000) Sulfur isotopic effects in the disproportionation reaction of sulfur dioxide in hydrothermal fluids: implications for the $\delta^{34} \mathrm{~S}$ variations of dissolved bisulfate and elemental sulfur from active crater lakes. J. Volcanol. Geoth. Res. 97(1-4), 287-307.

Lackschewitz K. S., Devey C. W., Stoffers P., Botz R., Eisenhauer A., Kummetz M., Schmidt M. and Singer A. (2004) Mineralogical, geochemical and isotopic characteristics of hydrothermal alteration processes in the active, submarine, felsic-hosted PACMANUS field, Manus Basin, Papua New Guinea. Geochim. Cosmochim. Acta 68(21), 4405-4427.

Lee S. M. (2003) Multidisciplinary investigation of the Western Pacific I (2000-2001). Ocean Polar Res. 24(3), 131-135.

Lee S. M. and Ruellan E. (2006) Tectonic and magmatic evolution of the Bismarck Sea, Papua New Guinea: review and new synthesis. In Back-Arc Spreading Systems: Geological, Biological, Chemical, and Physical Interactions, vol. 166 (eds. D. M. Christie, C. R. Fisher, S.-M. Lee and S. Givens). AGU Monograph. American Geophysical Union, pp. 263-286.

Lilley M. D., Butterfield D. A., Lupton J. E. and Olson E. J. (2003) Magmatic events can produce rapid changes in hydrothermal vent chemistry. Nature 422(6934), 878-881.

Lisitsyn A. P., Crook K., Bogdanov Y. A., Zonenshain L. P., Murav'yev K. G., Tufar W., Gurvich Y. G., Gordeyev V. V. and Ivanov G. V. (1993) A hydrothermal field in the rift zone of the Manus Basin, Bismarck Sea. Int. Geol. Rev. 35(2), 105-126.

Lowenstern J. B. (2000) A review of the contrasting behavior of two magmatic volatiles: chlorine and carbon dioxide. $J$. Geochem. Explor. 69, 287-290.

Lupton J., Butterfield D., Lilley M., Evans L., Nakamura K. I., Chadwick W., Resing J., Embley R., Olson E. and Proskurowski G., et al. (2006) Submarine venting of liquid carbon dioxide on a Mariana Arc volcano. Geochem. Geophys. Geosyst. 7(8), 1-20.

Lupton J., Lilley M., Butterfield D., Evans L., Embley R., Massoth G., Christenson B., Nakamura K. and Schmidt M. (2008) Venting of a separate $\mathrm{CO}_{2}$-rich gas phase from submarine arc volcanoes: examples from the Mariana and Tonga-Kermadec arcs. J. Geophys. Res.: Solid Earth 113(B8).

Maris C. R. P., Bender M. L., Froelich P. N., Barnes R. and Luedtke N. A. (1984) Chemical evidence for advection of hydrothermal solutions in the sediments of the Galápagos mounds hydrothermal field. Geochim. Cosmochim. Acta 48(11), 2331-2346.

Martinez F. and Taylor B. (1996) Backarc spreading, rifting, and microplate rotation, between transform faults in the Manus basin. Mar. Geophys. Res. 18(2-4), 203-224.
Marty B., Sano Y. and France-Lanord C. (2001) Water-saturated oceanic lavas from the Manus Basin: volatile behaviour during assimilation-fractional crystallisation-degassing (AFCD). $J$. Volcanol. Geoth. Res. 108(1-4), 1-10.

Massoth G. J., Butterfield D. A., Lupton J. E., McDuff R. E., Lilley M. D. and Jonasson I. R. (1989) Submarine venting of phase-separated hydrothermal fluids at Axial Volcano, Juan de Fuca Ridge. Nature 340(6236), 702-705.

Mattey D. P. (1991) Carbon dioxide solubility and carbon isotope fractionation in basaltic melt. Geochim. Cosmochim. Acta 55(11), 3467-3473.

McCollom T. M. and Seewald J. S. (2007) Abiotic synthesis of organic compounds in deep-sea hydrothermal environments. Chem. Rev. 107, 382-401.

McDermott J. M. and Von Damm K. L. (2008) On the redissolution of subsurface hydrothermal deposits at $9^{\circ} 50^{\prime} \mathrm{N}$ East Pacific Rise: implications from geochemical studies of high- and low-temperature fluids. EOS Trans. AGU 89(53), Fall Meet. Suppl. \#B51D-0402 (abstr.).

McMurtry G. M., Sedwick P. N., Fryer P., Vonderhaar D. L. and Yeh H. W. (1993) Unusual geochemistry of hydrothermal vents on submarine arc volcanos-Kasuga Seamounts, Northern Mariana Arc. Earth Planet. Sci. Lett. 114(4), 517-528.

Michael P. J. and Schilling J. G. (1989) Chlorine in mid-ocean ridge magmas: evidence for assimilation of seawater-influenced components. Geochim. Cosmochim. Acta 53(12), 3131-3143.

Michael P. J. and Cornell W. C. (1998) Influence of spreading rate and magma supply on crystallization and assimilation beneath mid-ocean ridges: evidence from chlorine and major element chemistry of mid-ocean ridge basalts. J. Geophys. Res.: Solid Earth 103(B8), 18325-18356.

Michard G., Albarède F., Michard A., Minster J. F., Charlou J. L. and Tan N. (1984) Chemistry of solutions from the $13^{\circ} \mathrm{N}$ East Pacific Rise hydrothermal site. Earth Planet. Sci. Lett. 67(3), 297-307.

Mills R. A. and Tivey M. (1999) Seawater entrainment and fluid evolution within the TAG hydrothermal mound: evidence from analyses of anhydrite. In Mid-Ocean Ridges: Dynamics of Processes Associated with Creation of New Ocean Crust (eds. J. R. Cann, H. Elderfield and A. Laughton). Cambridge University Press, pp. 225-248.

Monecke T., Giorgetti G., Scholtysek O., Kleeberg R., Gotze J., Hannington M. D. and Petersen S. (2007) Textural and mineralogical changes associated with the incipient hydrothermal alteration of glassy dacite at the submarine PACMANUS hydrothermal system, eastern Manus Basin. J. Volcanol. Geoth. Res. 160(1-2), 23-41.

Moss R. and Scott S. D. (2001) Geochemistry and mineralogy of gold-rich hydrothermal precipitates from the eastern Manus Basin, Papua New Guinea. Can. Mineral. 39, 957-978.

Mottl M. J. and Holland H. D. (1978) Chemical exchange during hydrothermal alteration of basalt by seawater: I. Experimental results for major and minor components of seawater. Geochim. Cosmochim. Acta 42(8), 1103-1115.

Mottl M. J., Holland H. D. and Corr R. F. (1979) Chemical exchange during hydrothermal alteration of basalt by seawater: II. Experimental results for $\mathrm{Fe}, \mathrm{Mn}$, and sulfur species. Geochim. Cosmochim. Acta 43(6), 869-884.

Nakagawa T., Takai K., Suzuki Y., Hirayama H., Konno U., Tsunogai U. and Horikoshi K. (2006) Geomicrobiological exploration and characterization of a novel deep-sea hydrothermal system at the TOTO caldera in the Mariana Volcanic Arc. Environ. Microbiol. 8(1), 37-49.

Nilsson K. and Peach C. L. (1993) Sulfur speciation, oxidation state, and sulfur concentration in backarc magmas. Geochim. Cosmochim. Acta 57(15), 3807-3813. 
Ogawa Y., Shikazono N., Ishiyama D., Sato H. and Mizuta T. (2005) An experimental study on felsic rock-artificial seawater interaction: implications for hydrothermal alteration and sulfate formation in the Kuroko mining area of Japan. Mineral. Deposita 39(8), 813-821.

Ohmoto H. and Rye R. (1979) Isotopes of sulfur and carbon. In Geochemistry of Hydrothermal Ore Deposits (ed. H. L. Barnes). Wiley, pp. 509-567.

Ohmoto H. and Lasaga A. C. (1982) Kinetics of reactions between aqueous sulfates and sulfides in hydrothermal systems. Geochim. Cosmochim. Acta 46(10), 1727-1745.

Ohmoto H. (1986) Stable isotope geochemistry of ore deposits. In Stable Isotopes in High Temperature Geological Processes, vol. 16 (eds. J. W. Valley, H. P. Taylor and J. R. O’Neil). Reviews in Mineralogy. Mineralogical Society of America, pp. 491559.

Ohmoto H. and Goldhaber M. B. (1997) Sulfur and carbon isotopes. In Geochemistry of Hydrothermal Ore Deposits (ed. H. L. Barnes). Wiley, pp. 517-612.

Park S. H., Lee S.-M., Kamenov G. D., Kwon S.-T. and Lee K.-Y. (2010) Tracing the origin of subduction components beneath the South East rift in the Manus Basin, Papua New Guinea. Chem. Geol. 269, 339-349.

Paulick H., Vanko D. A. and Yeats C. J. (2004) Drill core-based facies reconstruction of a deep-marine felsic volcano hosting an active hydrothermal system (Pual Ridge, Papau New Guinea, ODP Leg 193). J. Volcanol. Geoth. Res. 130(1-2), 31-50.

Paulick H. and Bach W. (2006) Phyllosilicate alteration mineral assemblages in the active subsea-floor Pacmanus hydrothermal system, Papua New Guinea, ODP Leg 193. Econ. Geol. 101(3), 633-650.

Pearce J. A. and Stern R. J. (2006) Origin of back-arc basin magmas: trace element and isotope perspectives. In Back-ArC Spreading Systems: Geological, Biological, Chemical, and Physical Interactions, vol. 166 (eds. D. M. Christie, C. R. Fisher, S.M. Lee and S. Givens). AGU Monograph. American Geophysical Union, pp. 63-86.

Pineau F., Javoy M. and Bottinga Y. (1976) ${ }^{13} \mathrm{C} /{ }^{12} \mathrm{C}$ ratios of rocks and inclusions in popping rocks of the mid-atlantic ridge and their bearing on the problem of isotopic composition of deepseated carbon. Earth Planet. Sci. Lett. 29, 413-421.

Pineau F., Shilobreeva S., Kadik A. and Javoy M. (1998) Water solubility and $\mathrm{D} / \mathrm{H}$ fractionation in the system basaltic andesite- $\mathrm{H}_{2} \mathrm{O}$ at $1250{ }^{\circ} \mathrm{C}$ and between 0.5 and 3 kbars. Chem. Geol. 147(1-2), 173-184.

Proskurowski G., Seewald J. S., Reeves E., McCollom T. M., Lupton J., Sylva S. P. and Tivey M. K. (2007) Volatile chemistry at Lau Basin hydrothermal sites: basin-wide trends of slab carbonate influence and suggestions of abiotic methane oxidation at the Mariner vent site. EOS Trans. AGU 88(52), Fall Meet. Suppl. \#V34B-04 (abst.).

Redfield A. C. and Friedman I. (1965) Factors affecting the distribution of deuterium in the ocean. In Symposium on Marine Geochemistry (eds. D. R. Schink and J. T. Corless). Occasional Publication No. 3. Narragansett Marine Laboratory, University of Rhode Island, pp. 149-168.

Rees C. E., Jenkins W. J. and Monster J. (1978) Sulfur isotopic composition of ocean water sulfate. Geochim. Cosmochim. Acta 42(4), 377-381.

Resing J. A., Lebon G., Baker E. T., Lupton J. E., Embley R. W., Massoth G. J., Chadwick W. W. and de Ronde C. E. J. (2007) Venting of acid-sulfate fluids in a high-sulfidation setting at NW Rota-1 submarine volcano on the Mariana Arc. Econ. Geol. 102(6), 1047-1061.

Resing J. A., Baker E. T., Lupton J. E., Walker S. L., Butterfield D. A., Massoth G. J. and Nakamura K. (2009) Chemistry of hydrothermal plumes above submarine volcanoes of the Mariana Arc. G Cubed $\mathbf{1 0 .}$

Roberts S., Bach W., Binns R. A., Vanko D. A., Yeats C. J., Teagle D. A. H., Blacklock K., Blusztajn J. S., Boyce A. J. and Cooper M. J., et al. (2003) Contrasting evolution of hydrothermal fluids in the PACMANUS system, Manus Basin: the $\mathrm{Sr}$ and $\mathrm{S}$ isotope evidence. Geology 31(9), 805-808.

Rosenbauer R. J. and Bischoff J. L. (1983) Uptake and transport of heavy metals by heated seawater: a summary of experimental results. In Hydrothermal Processes at Seafloor Spreading Centers, NATO Conference Series, vol. IV, no. 12 (Ed: P. Rona, K. Bostrom, L. Laubier, and K. Smith). Plenum Press.

Ryan J. G. and Langmuir C. H. (1993) The systematics of boron abundances in young volcanic rocks. Geochim. Cosmochim. Acta 57(7), 1489-1498.

Sakai H., Gamo T., Kim E. S., Shitashima K., Yanagisawa F., Tsutsumi M., Ishibashi J., Sano Y., Wakita H. and Tanaka T., et al. (1990a) Unique chemistry of the hydrothermal solution in the Mid-Okinawa Trough Backarc Basin. Geophys. Res. Lett. 17(12), 2133-2136.

Sakai H., Gamo T., Kim E. S., Tsutsumi M., Tanaka T., Ishibashi J., Wakita H., Yamano M. and Oomori T. (1990b) Venting of carbon dioxide-rich fluid and hydrate formation in MidOkinawa Trough Backarc Basin. Science 248(4959), 1093-1096.

Sarmiento J. L. and Gruber N. (2006) Ocean Biogeochemical Dynamics. Princeton University Press.

Scaillet B. and Pichavant M. (2003) Experimental constraints on volatile abundances in arc magmas and their implications for degassing processes. Geol. Soc. Lond. Spec. Publ. 213, 23-52.

Schoofs S. and Hansen U. (2000) Depletion of a brine layer at the base of ridge-crest hydrothermal systems. Earth Planet. Sci. Lett. 180(3-4), 341-353.

Sedwick P. N., McMurtry G. M. and Macdougall J. D. (1992) Chemistry of hydrothermal solutions from Pele Vents, Loihi Seamount, Hawaii. Geochim. Cosmochim. Acta 56(10), 36433667.

Seewald J. S. and Seyfried W. E. (1990) The effect of temperature on metal mobility in subseafloor hydrothermal systems: constraints from basalt alteration experiments. Earth Planet. Sci. Lett. 101(2-4), 388-403.

Seewald J. S., Doherty K. W., Hammar T. R. and Liberatore S. P. (2002) A new gas-tight isobaric sampler for hydrothermal fluids. Deep Sea Res. Part I 49(1), 189-196.

Seewald J., Cruse A. and Saccocia P. (2003) Aqueous volatiles in hydrothermal fluids from the Main Endeavour Field, northern Juan de Fuca Ridge: temporal variability following earthquake activity. Earth Planet. Sci. Lett. 216(4), 575-590.

Seewald J., McCollum T., Proskurowski G., Reeves E., Mottl M., Sharkey J., Wheat G. and Tivey M. K. (2005) Aqueous volatiles in Lau Basin hydrothermal fluids. EOS Trans. AGU 86(52), Fall Meet. Suppl. \#T31A-0478 (abstr.).

Seyfried W. E. and Bischoff J. L. (1981) Experimental seawaterbasalt interaction at $300^{\circ} \mathrm{C}, 500$ bars, chemical exchange, secondary mineral formation and implications for the transport of heavy metals. Geochim. Cosmochim. Acta 45(2), 135-147.

Seyfried W. E. and Mottl M. J. (1982) Hydrothermal alteration of basalt by seawater under seawater-dominated conditions. Geochim. Cosmochim. Acta 46(6), 985-1002.

Seyfried W. E., Janecky D. R. and Mottl M. J. (1984) Alteration of the oceanic crust: implications for geochemical cycles of lithium and boron. Geochim. Cosmochim. Acta 48(3), 557-569.

Seyfried W. E. and Janecky D. R. (1985) Heavy metal and sulfur transport during subcritical and supercritical hydrothermal alteration of basalt: influence of fluid pressure and basalt composition and crystallinity. Geochim. Cosmochim. Acta 49(12), 2545-2560. 
Seyfried W. E. (1987) Experimental and theoretical constraints on hydrothermal alteration processes at mid-ocean ridges. Аnnu. Rev. Earth Planet. Sci. 15, 317-335.

Seyfried W. E. and Ding K. (1995a) The hydrothermal chemistry of fluoride in seawater. Geochim. Cosmochim. Acta 59(6), 10631071.

Seyfried W. E. and Ding K. (1995b) Phase equilibria in subseafloor hydrothermal systems: a review of the role of redox, temperature, $\mathrm{pH}$ and dissolved $\mathrm{Cl}$ on the chemistry of hot spring fluids at mid-ocean ridges. In Seafloor Hydrothermal Systems: Physical, Chemical, Biological, and Geological Interactions, vol. 91 (eds. S. E. Humphris, R. A. Zierenberg, L. S. Mullineaux and R. E. Thomson). AGU Monograph. American Geophysical Union, pp. 248-272.

Shanks W. C. and Seyfried W. E. (1987) Stable isotope studies of vent fluids and chimney minerals, Southern Juan de Fuca Ridge: sodium metasomatism and seawater sulfate reduction. $J$. Geophys. Res.: Solid Earth Planets 92(B11), 11387-11399.

Shanks W. C., Böhlke J. K. and Seal R. R. (1995) Stable isotopes in mid-ocean ridge hydrothermal systems: interactions between fluids, minerals, and organisms. In Seafloor Hydrothermal Systems: Physical, Chemical, Biological, and Geological Interactions, vol. 91 (eds. S. E. Humphris, R. A. Zierenberg, L. S. Mullineaux and R. E. Thomson). AGU Monograph. American Geophysical Union, pp. 194-221.

Shanks W. C. (2001) Stable isotopes in seafloor hydrothermal systems: vent fluids, hydrothermal deposits, hydrothermal alteration, and microbial processes. In Stable Isotope Geochemistry, vol. 43 (eds. J. W. Valley and D. R. Cole). Reviews in Mineralogy \& Geochemistry. Mineralogical Society of America, pp. 469-525.

Shaw A. M., Hilton D. R., Macpherson C. G. and Sinton J. M. (2004) The $\mathrm{CO}_{2}-\mathrm{He}-\mathrm{Ar}-\mathrm{H}_{2} \mathrm{O}$ systematics of the Manus backarc basin: resolving source composition from degassing and contamination effects. Geochim. Cosmochim. Acta 68(8), 18371856.

Shaw A. M., Hauri E. H., Fischer T. P., Hilton D. R. and Kelley K. A. (2008) Hydrogen isotopes in Mariana arc melt inclusions: implications for subduction dehydration and the deep-Earth water cycle. Earth Planet. Sci. Lett. 275(1-2), 138-145.

Shikazono N. and Holland H. D. (1983) The partitioning of $\mathrm{Sr}$ between anhydrite and aqueous solutions from 150 to $250{ }^{\circ} \mathrm{C}$, the Kuroko and related volcanogenic massive sulfide deposits. Econ. Geol. Monogr. 5, 320-328.

Shinohara H. (1994) Exsolution of immiscible vapor and liquid phases from a crystallizing silicate melt: implications for chlorine and metal transport. Geochim. Cosmochim. Acta 58(23), 5215-5221.

Shiraki R., Sakai H., Endoh M. and Kishima N. (1987) Experimental studies on rhyolite-seawater and andesite-seawater interactions at $300^{\circ} \mathrm{C}$ and 1000 bars. Geochem. J. 21(4), 139148.

Shmulovich K. I., Landwehr D., Simon K. and Heinrich W. (1999) Stable isotope fractionation between liquid and vapour in water-salt systems up to $600^{\circ} \mathrm{C}$. Chem. Geol. 157(3-4), 343354.

Simmons S. F. and Brown K. L. (2006) Gold in magmatichydrothermal solutions and the rapid formation of a giant ore deposit. Science 314(5797), 288-291.

Sinton J. M., Ford L. L., Chappell B. and Mcculloch M. T. (2003) Magma genesis and mantle heterogeneity in the Manus backarc basin, Papua New Guinea. J. Petrol. 44(1), 159-195.

Snyder G. T., Fehn U. and Goff R. (2002) Iodine isotope ratios and halide concentrations in fluids of the Satsuma-Iwojima volcano, Japan. Earth Planets Space 54(3), 265-273.
Spencer D. W., Robertson D. E., Turekian K. K. and Folsom T. R. (1970) Trace element calibrations and profiles at the GEOSECS test station in the Northeast Pacific Ocean. J. Geophys. Res. 75(36), 7688-7696.

Spivack A. J. and Edmond J. M. (1987) Boron isotope exchange between seawater and the oceanic crust. Geochim. Cosmochim. Acta 51(5), 1033-1043.

Stoffers P., Worthington T. J., Schwarz-Schampera U., Hannington M. D., Massoth G. J., Hekinian R., Schmidt M., Lundsten L. J., Evans L. J. and Vaiomo'unga R., et al. (2006) Submarine volcanoes and high-temperature hydrothermal venting on the Tonga arc, southwest Pacific. Geology 34(6), 453-456.

Sun W. D., Arculus R. J., Kamenetsky V. S. and Binns R. A. (2004) Release of gold-bearing fluids in convergent margin magmas prompted by magnetite crystallization. Nature 431(7011), 975-978.

Sun W. D., Binns R. A., Fan A. C., Kamenetsky V. S., Wysoczanski R., Wei G. J., Hu Y. H. and Arculus R. J. (2007) Chlorine in submarine volcanic glasses from the eastern Manus basin. Geochim. Cosmochim. Acta 71(6), 1542-1552.

Takai K., Nunoura T., Ishibashi J. I., Lupton J., Suzuki R., Hamasaki H., Ueno Y., Kawagucci S., Gamo T. and Suzuki Y., et al. (2008) Variability in the microbial communities and hydrothermal fluid chemistry at the newly discovered Mariner hydrothermal field, southern Lau Basin. J. Geophys. Res.: Biogeosci. 113(G02031). doi:10.1029/2007JG000636.

Taylor B. (1979a) Bismarck Sea: evolution of a back-arc basin. Geology 7(171-174).

Taylor B., Crook K. and Sinton J. (1994) Extensional transform zones and oblique spreading centers. J. Geophys. Res.: Solid Earth 99(B10), 19707-19718.

Taylor H. P. (1979b) Oxygen and hydrogen isotope relationships in hydrothermal mineral deposits. In Geochemistry of Hydrothermal Ore Deposits (ed. H. L. Barnes). Wiley, pp. 236-277.

Taylor H. P. (1986) Magmatic volatiles: isotopic variation of C, H, and S. In Stable Isotopes in High Temperature Geological Processes, vol. 16 (eds. J. W. Valley, H. P. Taylor and J. R. O'Neil). Reviews in Mineralogy. Mineralogical Society of America, pp. 185-225.

Taylor H. P. (1997) Oxygen and hydrogen isotope relationships in hydrothermal mineral deposits. In Geochemistry of Hydrothermal Ore Deposits (ed. H. L. Barnes). Wiley, pp. 229-302.

Tivey M., Bach W., Seewald J., Tivey M. K., Vanko D. A., and the Shipboard Science Party (2006) Cruise Report for R/V Melville Cruise MGLN06MV-Hydrothermal Systems in the Eastern Manus Basin: Fluid Chemistry and Magnetic Structure as Guides to Subseafloor Processes. Woods Hole Oceanographic Institution. http://hdl.handle.net/1912/4077.

Tivey M. K., Humphris S. E., Thompson G., Hannington M. D. and Rona P. A. (1995) Deducing patterns of fluid flow and mixing within the TAG active hydrothermal mound using mineralogical and geochemical data. J. Geophys. Res.: Solid Earth 100(B7), 12527-12555.

Trefry J. H., Butterfield D. B., Metz S., Massoth G. J., Trocine R. P. and Feely R. A. (1994) Trace metals in hydrothermal solutions from cleft segment on the southern Juan de Fuca Ridge. J. Geophys. Res.: Solid Earth 99(B3), 4925-4935.

Tregoning P. (2002) Plate kinematics in the western Pacific derived from geodetic observations. J. Geophys. Res.: Solid Earth 107(B1).

Tsunogai U., Ishibashi J., Wakita H., Gamo T., Watanabe K., Kajimura T., Kanayama S. and Sakai H. (1994) Peculiar features of Suiyo Seamount hydrothermal fluids, Izu-Bonin Arc: differences from subaerial volcanism. Earth Planet. Sci. Lett. 126(4), 289-301. 
Tufar W. (1990) Modern hydrothermal activity, formation of complex massive sulfide deposits and associated vent communities in the Manus Back-arc Basin (Bismarck Sea, Papua New Guinea). Mitteilung der Osterreichen Geologischen Gesellshaft 82, 183-210.

Vanko D. A., Bach W., Roberts S., Yeats C. J. and Scott S. D. (2004) Fluid inclusion evidence for subsurface phase separation and variable fluid mixing regimes beneath the deep-sea PACMANUS hydrothermal field, Manus Basin back arc rift, Papua New Guinea. J. Geophys. Res.: Solid Earth 109(B3). doi:10.1029/2003JB002579.

Von Damm K. L., Edmond J. M., Grant B. and Measures C. I. (1985) Chemistry of submarine hydrothermal solutions at $21^{\circ} \mathrm{N}$, East Pacific Rise. Geochim. Cosmochim. Acta 49(11), $2197-2220$.

Von Damm K. L. and Bischoff J. L. (1987) Chemistry of hydrothermal solutions from the Southern Juan De Fuca Ridge. J. Geophys. Res.: Solid Earth Planets 92(B11), 1133411346.

Von Damm K. L. (1988) Systematics of and postulated controls on submarine hydrothermal solution chemistry. J. Geophys. Res.: Solid Earth Planets 93(B5), 4551-4561.

Von Damm K. L. (1990) Seafloor hydrothermal activity_black smoker chemistry and chimneys. Annu. Rev. Earth Planet. Sci. 18, 173-204.

Von Damm K. L., Bischoff J. L. and Rosenbauer R. J. (1991) Quartz solubility in hydrothermal seawater: an experimental study and equation describing quartz solubility for up to $0.5 \mathrm{M}$ $\mathrm{NaCl}$ solutions. Am. J. Sci. 291(10), 977-1007.

Von Damm K. L. (1995) Controls on the chemistry and temporal variability of seafloor hydrothermal systems. In Seafloor Hydrothermal Systems: Physical, Chemical, Biological, and Geological Interactions, vol. 91 (eds. S. E. Humphris, R. A. Zierenberg, L. S. Mullineaux and R. E. Thomson). AGU Monograph. American Geophysical Union, pp. 222-247.

Von Damm K. L., Bray A. M., Buttermore L. G. and Oosting S. E. (1998) The geochemical controls on vent fluids from the Lucky Strike vent field, Mid-Atlantic Ridge. Earth Planet. Sci. Lett. 160(3-4), 521-536.

Von Damm K. L., Parker C. M., Zierenberg R. A., Lilley M. D., Olson E. J., Clague D. A. and Mcclain J. S. (2005) The
Escanaba Trough, Gorda Ridge hydrothermal system: temporal stability and subseafloor complexity. Geochim. Cosmochim. Acta 69(21), 4971-4984.

Wallace P. J. (2005) Volatiles in subduction zone magmas: concentrations and fluxes based on melt inclusion and volcanic gas data. J. Volcanol. Geoth. Res. 140(1-3), 217-240.

Webster J. D. (2004) The exsolution of magmatic hydrosaline chloride liquids. Chem. Geol. 210(1-4), 33-48.

Welhan J. A. (1988) Origins of methane in hydrothermal systems. Chem. Geol. 71(1-3), 183-198.

Woodruff L. G. and Shanks W. C. (1988) Sulfur isotope study of chimney minerals and vent fluids from $21^{\circ} \mathrm{N}$, East Pacific Rise-hydrothermal sulfur sources and disequilibrium sulfate reduction. J. Geophys. Res.: Solid Earth Planets 93(B5), 45624572.

Yang K. H. and Scott S. D. (1996) Possible contribution of a metal-rich magmatic fluid to a sea-floor hydrothermal system. Nature 383(6599), 420-423.

Yang K. H. and Scott S. D. (2002) Magmatic degassing of volatiles and ore metals into a hydrothermal system on the modern sea floor of the eastern Manus back-arc basin, western Pacific. Econ. Geol. 97(5), 1079-1100.

Yang K. H. and Scott S. D. (2005) Vigorous exsolution of volatiles in the magma chamber beneath a hydrothermal system on the modern sea floor of the eastern Manus back-arc basin, western Pacific: evidence from melt inclusions. Econ. Geol. 100(6), 10851096.

Yang K. H. and Scott S. D. (2006) Magmatic fluids as a source of metals in seafloor hydrothermal systems. In Back-Arc Spreading Systems: Geological, Biological, Chemical, and Physical Interactions, vol. 166 (eds. D. M. Christie, C. R. Fisher, S.-M. Lee and S. Givens). AGU Monograph. American Geophysical Union, pp. 163-184.

Zengqian H., Zaw K., Yahne L., Qiling Z., Zhignag Z. and Urabe T. (2005) Contribution of magmatic fluid to the active hydrothermal system in the JADE Field, Okinawa Trough: evidence from fluid inclusions, oxygen and helium isotopes. Int. Geol. Rev. 47, 420-437.

Associate editor: Jun-ichiro Ishibashi 